



\section{USER GUIDE FOR \\ PROCUREMENT OF GOODS STANDARD BIDDING DOCUMENT}

DECEMBER 2021 


\section{(c) $\$($ Creative Commons Attribution-NonCommercial-NoDerivs 3.0 IGO license BY NC ND (CC BY-NC-ND 3.0 IGO)}

(C) 2021 Asian Development Bank

6 ADB Avenue, Mandaluyong City, 1550 Metro Manila, Philippines

Tel +632 8632 4444; Fax +63286362444

www.adb.org

Some rights reserved. Published in 2021.

ISBN 978-92-9269-292-6 (print); 978-92-9269-293-3 (electronic)

Publication Stock No. TIM210533-2

DOI: http://dx.doi.org/10.22617/TIM210533-2

The views expressed in this publication are those of the authors and do not necessarily reflect the views and policies of the Asian Development Bank (ADB) or its Board of Governors or the governments they represent.

ADB does not guarantee the accuracy of the data included in this publication and accepts no responsibility for any consequence of their use. The mention of specific companies or products of manufacturers does not imply that they are endorsed or recommended by ADB in preference to others of a similar nature that are not mentioned.

By making any designation of or reference to a particular territory or geographic area, or by using the term "country" in this document, ADB does not intend to make any judgments as to the legal or other status of any territory or area.

This work is available under the Creative Commons Attribution-NonCommercial-NoDerivs 3.0 IGO license (CC BY-NC-ND 3.0 IGO) http://creativecommons.org/licenses/by-nc-nd/3.0/igo/. By using the content of this publication, you agree to be bound by the terms of this license. For attribution and permissions, please read the provisions and terms of use at https://www.adb.org/terms-use\#openaccess.

This CC license does not apply to non-ADB copyright materials in this publication. If the material is attributed to another source, please contact the copyright owner or publisher of that source for permission to reproduce it. ADB cannot be held liable for any claims that arise as a result of your use of the material.

Please contact pubsmarketing@adb.org if you have questions or comments with respect to content, or if you wish to obtain copyright permission for your intended use that does not fall within these terms, or for permission to use the ADB logo.

Corrigenda to ADB publications may be found at http://www.adb.org/publications/corrigenda.

Notes:

In this document, “\$” refers to United States dollars.

This document applies to projects governed by the Procurement Regulations for ADB Borrowers:

Goods, Works, Nonconsulting and Consulting Services (2017, as amended from time to time). 


\section{Contents}

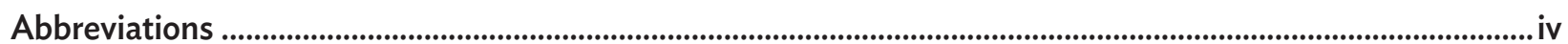

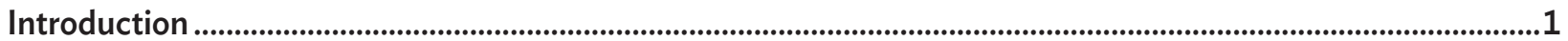

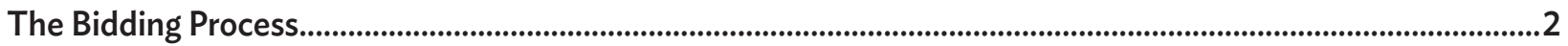

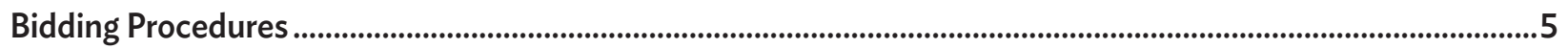

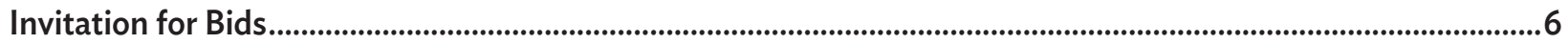

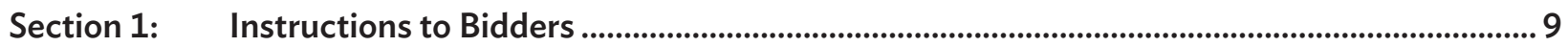

This section specifies the procedures to be followed by Bidders in the preparation and submission of their

Bids, and the procedures to be followed by the Purchaser on the submission, opening, and evaluation of bids

and on the award of contract.

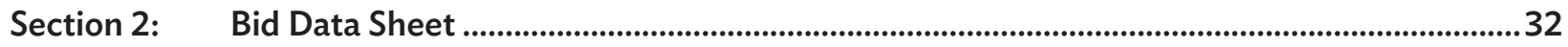

This section consists of provisions that are specific to each procurement and supplements the information or requirements included in Section 1 - Instructions to Bidders.

\section{Section 3: Evaluation and Qualification Criteria}

This section contains the criteria to determine the lowest evaluated bid and the qualifications of the Bidder to perform the contract if the bidding were not preceded by a prequalification exercise.

\section{Section 4: Bidding Forms}

This section contains the forms to be completed by the Bidder and submitted as part of its Bid if the bidding were not preceded by a prequalification exercise.

Section 5: Eligible Countries..

This section contains the list of eligible countries.

\section{Section 6: Schedule of Supply}

This section contains the List of Goods and Related Services, Delivery and Completion Schedule, Technical Specifications, and Drawings.

\section{Section 7: General Conditions of Contract}

This section contains the general clauses to be applied in all contracts. These Conditions are subject to the variations and additions set out in Section 8 (Special Conditions of Contract).

\section{Section 8: Special Conditions of Contract.}

This section contains provisions that are specific to each contract and that modify or supplement the General Conditions of Contract. Whenever there is a conflict, the provisions herein shall prevail over those in the General Conditions of Contract.

\section{Section 9: Contract Forms}

This section contains forms that, once completed, will form part of the Contract. The forms for Performance Security and Advance Payment Security, when required, shall only be completed by the successful Bidder after contract award. 


\title{
Abbreviations
}

\author{
ADB........................ Asian Development Bank \\ BDF ........................ Bidding Forms \\ BDS ....................... Bid Data Sheet \\ COF........................ Contract Forms \\ CON ....................... Historical Contract Nonperformance \\ DCS ....................... Delivery and Completion Schedule \\ ELC ........................ Eligible Countries \\ EQC ......................... Evaluation and Qualification Criteria \\ GCC ....................... General Conditions of Contract \\ ICC .......................... International Chamber of Commerce \\ IFB............................ Invitation for Bids \\ Incoterms............... International Commercial Terms \\ ITB .......................... Instructions to Bidders \\ LGRS....................... List of Goods and Related Services \\ OAI ......................... Office of Anticorruption and Integrity \\ OCB ....................... Open Competitive Bidding \\ SBD ........................ Standard Bidding Document \\ SCC ………….......... Special Conditions of Contract
}




\section{Introduction}

The Asian Development Bank (ADB) has adopted two bidding procedures from which the Purchaser may select one to suit the nature of the particular procurement. The bidding procedures are as follows:

(a) Single-Stage: One-Envelope, and

(b) Single-Stage: Two-Envelope.

Accordingly, two types of standard bidding documents (SBD) for the procurement of goods and related services have been prepared to facilitate the two bidding procedures. Detailed information on bidding procedures is given under the section "Bidding Procedures."

This guide has been prepared to cover the single-stage: one-envelope type of SBD for procurement of goods and related services. The SBD has been designed to

(a) simplify the Purchaser's preparation of a specific Bidding Document for procurement of goods and related services;

(b) reduce bidders' bidding time and effort;

(c) facilitate and simplify the Purchaser's evaluation and comparison of bids and contract award; and

(d) minimize time required for ADB's prior review of the Bidding Document.

Another important feature of the SBD is that it can be used with minimum changes, as it does not contain explanations, footnotes, or examples that should not form part of the Bidding Document. The SBD is only available in electronic format and can be found on the ADB website.

The purpose of this guide is to provide guidance to Purchasers on how to prepare a Bidding Document based on the SBD.

The provisions in Section 1 (Instructions to Bidders) and Section 7 (General Conditions of Contract), must be used with their text unchanged. Any data and provisions that these sections require for a specific procurement and contract shall be included respectively in Section 2 (Bid Data Sheet) and Section 8 (Special Conditions of Contract).

This guide includes a section on how to prepare the Invitation for Bids. The Purchaser should note that the Invitation for Bids is neither a part of the Bidding Document nor a contract document.

ADB welcomes any feedback or experiences from both borrowers and bidders on the use of its SBD. For information on procurement under $\mathrm{ADB}$-financed projects, contact

Procurement, Portfolio and Financial Management Department (PPFD)

Asian Development Bank

6 ADB Avenue, Mandaluyong City

1550 Metro Manila, Philippines

E-mail: procurement@adb.org

Tel: +63286324444

Fax: +63286362444 [Attn: Director General, PPFD]

www.adb.org 


\section{The Bidding Process}

The open competitive bidding (OCB) method includes six main phases: (i) advertisement and notification, preparing and issuing the Bidding Document, (iii) bid preparation and submission, (iv) bid opening, (v) bid evaluation, and (vi) contract award.

\section{Advertisement and Notification}

Invitation for Bids (IFB) shall be advertised on the Asian Development Bank (ADB) website; on a freely and publicly accessible website in English; and in a newspaper of national circulation (at least in one English language newspaper, if available) or website in the borrower's country. A copy of the IFB shall be submitted to ADB for no-objection and for publication on the ADB website in accordance with the Procurement Regulations for ADB Borrowers: Goods, Works, Nonconsulting and Consulting Services (2017, as amended from time to time).

For large or specialized contracts, ADB may additionally require that the IFB be advertised in well-known technical magazines or trade publications, or in newspapers of wide international circulation, with sufficient time to enable prospective Bidders to prepare and submit Bids.

\section{Preparing and Issuing a Bidding Document}

The Purchaser and Bidder should keep the following in mind:

(a) The Purchaser is responsible for preparing and issuing the Bidding Document for a specific contract.

(b) The Bidding Document shall be prepared by the Purchaser based on the appropriate Standard Bidding Document (SBD) issued by $A D B$, as this is a mandatory requirement for contracts to be financed by ADB.

(c) The Purchaser shall prepare the Bidding Document using the published version of the SBD without suppressing or adding text to the sections of the document that must be used without modification, which are Section 1 (Instructions to Bidders) and Section 7 (General Conditions of Contract). All information and data particular to each individual bidding process must be provided by the Purchaser in the following sections of the Bidding Document:

- Section 2 (Bid Data Sheet)

- Section 3 (Evaluation and Qualification Criteria)

- Section 4 (Bidding Forms)

- Section 5 (Eligible Countries)

- Section 6 (Schedule of Supply)

- Section 8 (Special Conditions of Contract)

- Section 9 (Contract Forms)

The following directions should be observed by the Purchaser when finalizing the Bidding Document:

- In preparing the Bidding Document, the Purchaser should refer to this User Guide for Procurement of Goods as it contains guidance and instructions for the Purchaser. 
- Specific details, such as name of the Purchaser, address for bid submissions, qualification requirements, electronic procurement procedures, etc. should be provided in the spaces indicated by italicized notes in brackets.

- The italicized notes giving guidance and instructions for the Purchaser, except those that apply to forms to be filled out by Bidders, should be deleted from the actual Bidding Document.

- Where alternative clauses or text are given, the Purchaser shall select the most appropriate for the particular goods and related services and discard the unused clauses or text.

The Purchaser shall allow Bidders sufficient time (generally, not less than 6 weeks from the issuance or publication date of the Invitation for Bids or the date of availability of the Bidding Document, whichever is later), to study the Bidding Document, prepare complete and responsive bids, and submit their bids.

\section{Bid Preparation and Submission}

The Bidder is solely responsible for the preparation and submission of its Bid. During this stage, the Purchaser shall

(a) promptly respond to requests for clarifications from Bidders and amend the Bidding Document as needed; and

(b) amend the Bidding Document only with the prior approval of ADB in case the contract is subject to prior review.

\section{Bid Opening}

The Purchaser is responsible for the Bid Opening, which is a critical event in the bidding process. The Purchaser shall appoint experienced staff to conduct the Bid Opening, as inappropriate procedures at Bid Opening are usually irreversible and may lead to cancellation of the bidding process with consequent delays and waste of resources.

The Purchaser, in observance of best practices, shall perform the following checks:

(a) Conduct the Bid Opening, strictly following the procedures specified in the Instructions to Bidders (ITB) for all Bids received not later than the date and time of the bid submission deadline. The term "Bid Opening" should be understood in the context of the ITB because, as provided in the ITB, a Bid for which a Bid Withdrawal or Bid Substitution notice was received on time shall not be opened, but returned unopened to the Bidder. The sequence in which Bids are handled, opened, and recorded is crucial.

(b) Ensure that all Bids that were received on time are accounted for, before starting the Bid Opening, as Bids that are not opened and read out at Bid Opening shall not be considered further.

(c) Not reject any Bid at Bid Opening, except for late bids received after the date and time of the bid submission deadline. Technically, late bids should not reach the Bid Opening, but in certain cases a Bidder may attempt to submit its bid at the Bid Opening place after the deadline. This late bid shall also not be considered.

(d) Examine the Bids at Bid Opening in accordance with the provisions of the ITB. The Purchaser shall, however, verify at Bid Opening the validity of the documentation, such as Power of Attorney or other acceptable equivalent document as specified in the ITB. The validity of a bid modification, bid withdrawal, or bid substitution should be confirmed because a withdrawn or substituted bid shall not be opened, or read out and, therefore, shall not be considered by the Purchaser. A valid bid modification shall be opened, read out, and recorded to modify a Bid that was received on time. 


\section{Bid Evaluation and Contract Award}

The Purchaser is responsible for bid evaluation and contract award. The Purchaser shall appoint experienced staff to conduct the evaluation of the Bids. Mistakes committed at bid evaluation may later prompt complaints from Bidders, requiring reevaluation of the Bids, with consequent delays and waste of resources.

The Purchaser, in observance of best practices, shall

(a) keep the bid evaluation process strictly confidential;

(b) reject attempts or pressures to distort the outcome of the evaluation, including fraud and corruption; and

(c) strictly apply only and all of the evaluation and qualification criteria specified in the Bidding Document.

\section{Use of Electronic Procurement System}

When an electronic procurement system is used, the applicable procedures of the bidding process such as (i) advertisement and notification; (ii) preparing and issuing the Bidding Document; (iii) bid preparation and submission; (iv) bid opening; (v) bid evaluation; and (vi) contract award, including the means of communication between the Purchaser and Bidders, shall be specified in the relevant clauses of Section 2 (Bid Data Sheet). 


\section{Bidding Procedures}

ADB has adopted two bidding procedures from which the Purchaser may select one to suit the nature of the particular procurement. The bidding procedures are as follows:

(a) Single-Stage: One-Envelope. The main bidding procedure used for most of the procurement financed by ADB.

(b) Single-Stage: Two-Envelope. Allows bids to be evaluated on purely technical and administrative grounds without reference to price.

\section{Single-Stage: One-Envelope Bidding Procedure}

In the Single-Stage: One-Envelope bidding procedure, Bidders submit Bids in one envelope containing both the Technical Bid and the Price Bid. The envelopes are opened in public at the date and time advised in the Bidding Document. The Bids are evaluated, and following approval by ADB, the Contract is awarded to the Bidder whose Bid has been determined to be the lowest evaluated substantially responsive Bid.

\section{Single-Stage: Two-Envelope Bidding Procedure}

In the Single-Stage: Two-Envelope bidding procedure, Bidders submit two sealed envelopes simultaneously, one containing the Technical Bid and the other the Price Bid, enclosed together in an outer single envelope. Initially, only the Technical Bids are opened on the date and time advised in the Bidding Document. The Price Bids remain sealed and are held in custody by the Purchaser. The Technical Bids are evaluated by the Purchaser. No amendments or changes to the Technical Bids are permitted. The objective of the exercise is to allow the Purchaser to evaluate the Technical Bids without reference to price. Bids of Bidders that do not conform to the specified requirements may be rejected as deficient Bids. Following ADB approval of the technical evaluation in case the contract is subject to prior review and at an address, date, and time advised by the Purchaser, the Price Bids are opened in public. The Price Bids are evaluated and, following ADB approval of the price evaluation in case the contract is subject to prior review, the Contract is awarded to the Bidder whose Bid has been determined to be the lowest evaluated substantially responsive Bid. 


\section{Invitation for Bids}

The Invitation for Bids (IFB) provides information that enables potential Bidders to decide whether to participate. Apart from the essential items listed in the Standard Bidding Document, the IFB should also indicate any important bid evaluation criteria (for example, the application of domestic preference in bid evaluation) and qualification criteria (for example, a requirement for a minimum level of experience in manufacturing or supplying a similar type of goods for which the IFB is issued).

The IFB is not a part of the Bidding Document and therefore it shall not be included in the Bidding Document.

The IFB shall be advertised on the Asian Development Bank (ADB) website; on a freely and publicly accessible website in English; and in a newspaper of national circulation (at least in one English language newspaper, if available) or website in the borrower's country. A copy of the IFB shall be submitted to ADB for no-objection and for publication on the ADB website in accordance with the Procurement Regulations for ADB Borrowers: Goods, Works, Nonconsulting and Consulting Services (2017, as amended from time to time).

For large or specialized contracts, ADB may additionally require that the IFB be advertised in well-known technical magazines or trade publications, or in newspapers of wide international circulation, with sufficient time to enable prospective Bidders to prepare and submit Bids. 


\title{
Standard Format for Invitation for Bids
}

\author{
[Letterhead of the Purchaser]
}

\author{
Date... \\ Loan/Grant No. and Title \\ Contract No. and Title. \\ Deadline for Submission of Bids \\ [insert closing date and time]
}

1. The [insert name of the Borrower or recipient] has received ${ }^{1}$ financing from the Asian Development Bank (ADB) toward the cost of [insert name of the project], and it intends to apply part of the proceeds of this financing to payments under the contract ${ }^{2}$ named above. Bidding is open to Bidders ${ }^{3}$ from eligible source countries of $\mathrm{ADB} .^{4}$

2. The [insert name of the Purchaser] ("the Purchaser") invites sealed bids from eligible Bidders ${ }^{3}$ for [insert description of goods and related services to be procured $]^{5,6}$

3. Open competitive bidding will be conducted in accordance with ADB's [insert appropriate bidding procedure] ${ }^{7}$ procedure and is open to all Bidders from eligible countries as described in the Bidding Document. ${ }^{8}$

4. Only eligible Bidders with the following key qualifications ${ }^{9}$ defined in the Bidding Document may participate in this bidding:

[insert key experience requirement]

[insert key financial requirement]

5. To obtain further information and inspect the Bidding Documents, Bidders should contact:

[insert Purchaser's office $]^{10}$

[insert name of the officer]

[insert postal address or street address, include zip code]

[insert telephone number including country code]

[insert e-mail address]

[insert fax number]

Substitute with "has applied for" if appropriate.

Substitute "contracts" where bids are called concurrently for multiple contracts. Add the following as a new paragraph 2 and renumber paragraphs 2-8: "Bidders may bid for one or several contracts, as further defined in the Bidding Document. Bidders wishing to offer discounts in case they are awarded more than one contract will be allowed to do so provided those discounts are included in the Bid Submission Sheet."

3 Insert "prequalified" if the bidding is preceded by a prequalification exercise.

$4 \quad$ Insert if applicable: "This contract will be jointly financed by [insert name of cofinancing agency]. The eligibility rules and procedures of ADB will govern the bidding process."

5 A brief description of the type of goods and related services should be provided, including quantities, location of project, and other information necessary to enable potential bidders to decide whether to respond to the invitation. The Bidding Document may require bidders to have specific experience or capabilities; such requirements should also be included in this paragraph. Insert if applicable: "The delivery/completion period is [insert no. of days/months/years or dates]"

Insert one of the bidding procedures adopted by ADB: (a) Single-Stage: One-Envelope and (b) Single-Stage: Two-Envelope. Occasionally, contracts may be financed out of Special Funds, which would further restrict eligibility to a particular group of ADB members. When this is the case, it should be mentioned in this paragraph. The list of eligible countries will be specified in Section 5 of the Bidding Document.

$9 \quad$ Insert an additional paragraph indicating key qualification criteria consistent with the bidding document to enable potential Bidders to decide whether to respond to the invitation.

10 The Borrower and the Purchaser may be the same or different entities. The text of the Invitation for Bids and the texts of the other associated documents must indicate which agency will act as the Purchaser. 
6. To purchase the Bidding Documents in English, eligible Bidders should

- write to the address above requesting the Bidding Documents for [insert number and title of the contract], and

- pay a nonrefundable fee ${ }^{11}$ of [insert amount and currency] by [insert method of payment]. ${ }^{12}$

The document will be sent by [insert delivery procedure]. ${ }^{13}$ No liability will be accepted for loss or late delivery.

7. Deliver your bid:

- to the address [insert address],

- on or before the deadline: [insert closing date and time consistent with the Bidding Document], and

- together with a Bid Security/Bid-Securing Declaration as described in the Bidding Document.

Bids will be opened promptly after the deadline for bid submission in the presence of Bidders' representatives who choose to attend.

8. When comparing Bids, Domestic Preference will be applied as stipulated in the Bidding Document. ${ }^{14}$

The fee chargeable should only be nominal to cover reproduction and mailing or shipping costs.

For example, cashier's check, direct deposit to a specified account number, etc.

13 The delivery procedure is usually airmail for overseas delivery and surface mail or courier for local delivery. If urgency or security dictates, courier services may be required for overseas delivery.

14 Include para. 8 only if Domestic Preference has been expressly provided in the Procurement Plan and is included in the Bid Data Sheet. 


\section{Section 1: Instructions to Bidders}

The Instructions to Bidders (ITB) specify the procedures that regulate the bidding process. The ITB contains standard provisions that have been designed to remain unchanged and to be used without modifying their text. The ITB clearly identifies the provisions that may need to be specified for a particular bidding process and requires that such specification be introduced through the Bid Data Sheet (BDS).

The ITB is not a Contract document and, therefore, is not a part of the Contract.

\section{Table of Clauses}

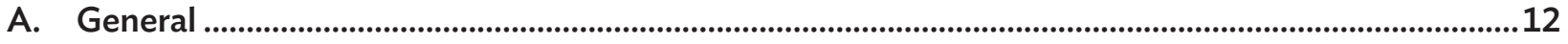

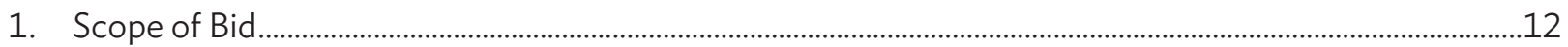

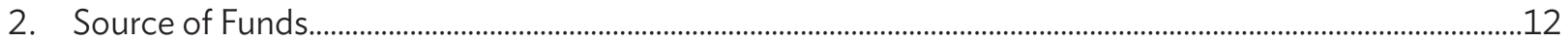

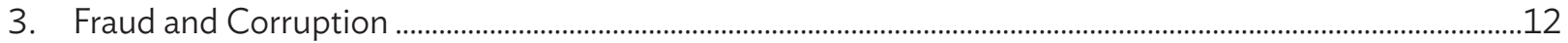

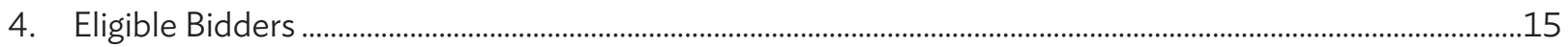

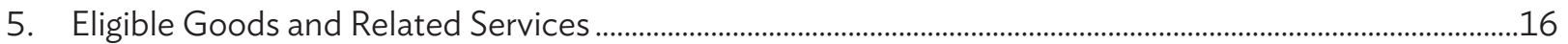

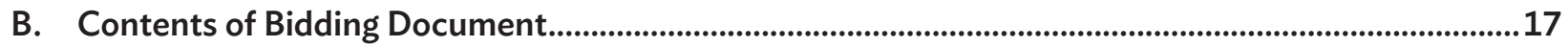

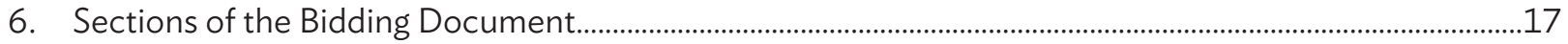

7. Clarification of Bidding Document..................................................................................................................

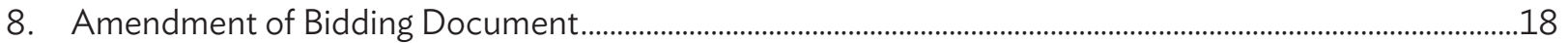

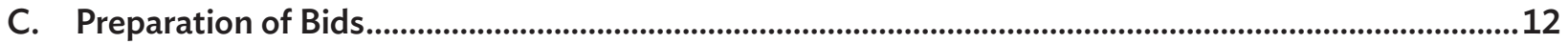

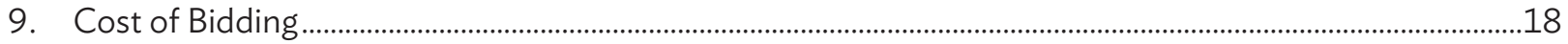

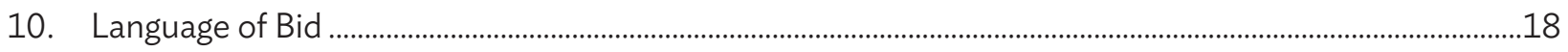

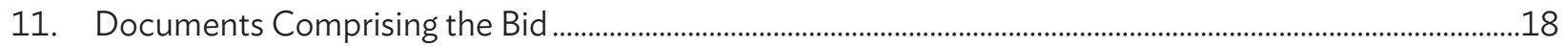

12. Bid Submission Sheet and Price Schedules...................................................................................................

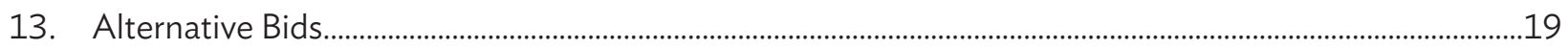

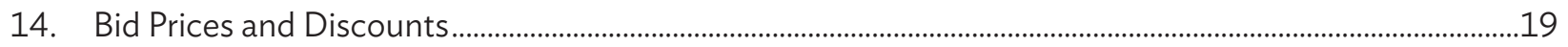

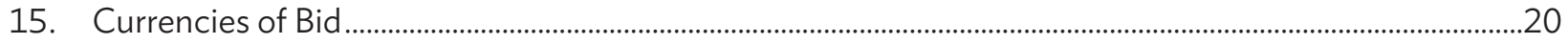

16. Documents Establishing the Eligibility of the Bidder............................................................................................ 
17. Documents Establishing the Eligibility of the Goods and Related Services

18. Documents Establishing the Conformity of the Goods and Related Services

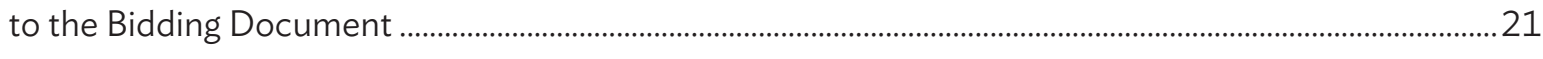

19. Documents Establishing the Qualifications of the Bidder .................................................................................21

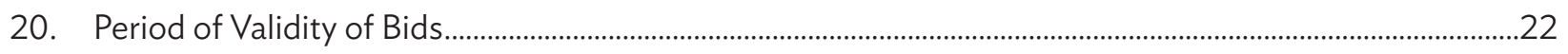

21. Bid Security/Bid-Securing Declaration ...............................................................................................................2

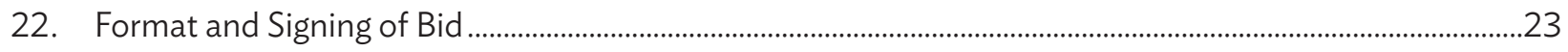

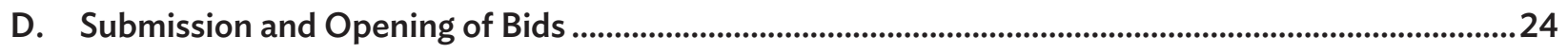

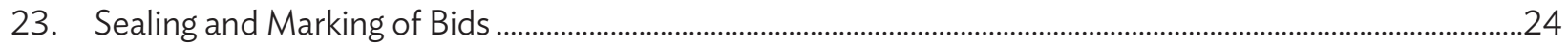

24. Deadline for Submission of Bids...........................................................................................................................24

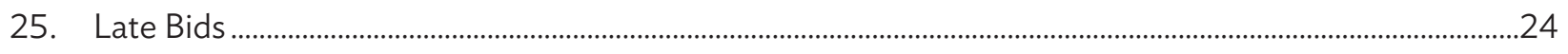

26. Withdrawal, Substitution, and Modification of Bids ........................................................................................24

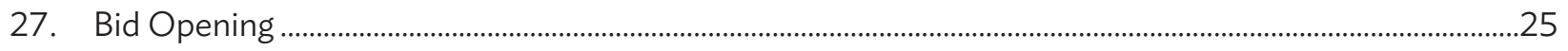

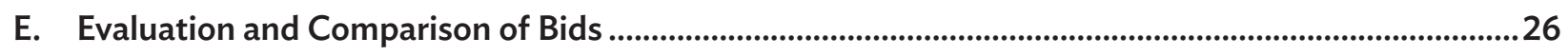

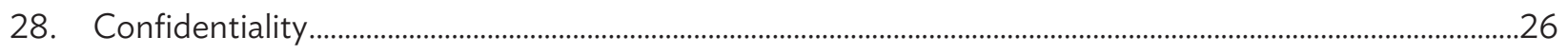

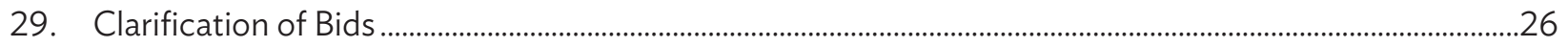

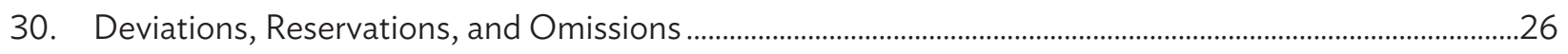

31. Determination of Responsiveness................................................................................................................................26

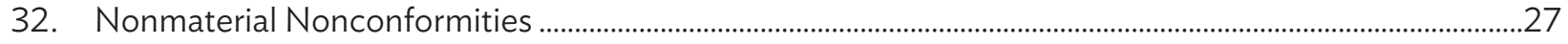

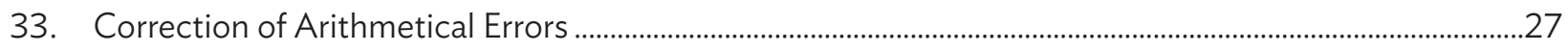

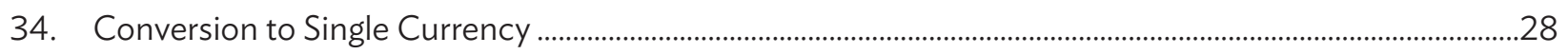

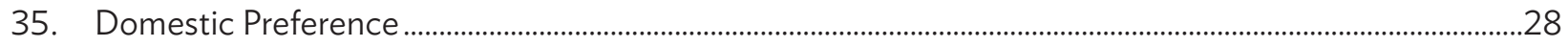

36. Evaluation and Comparison of Bids .................................................................................................................2

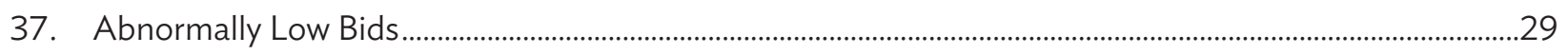

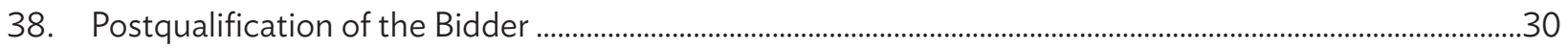

39. Purchaser's Right to Accept Any Bid, and to Reject Any or All Bids ..................................................................30

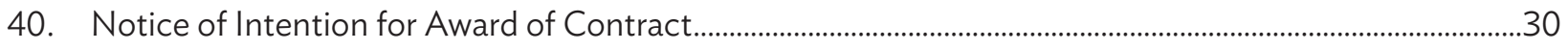




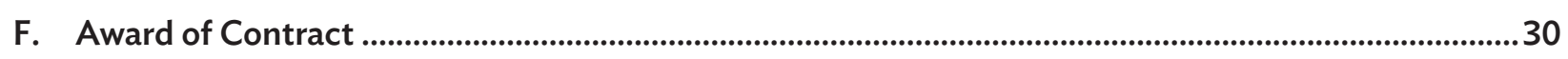

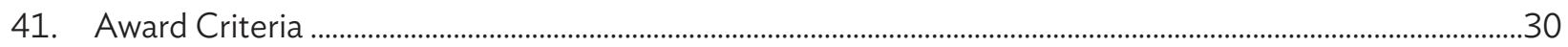

42. Purchaser's Right to Vary Quantities at Time of Award ...................................................................................30

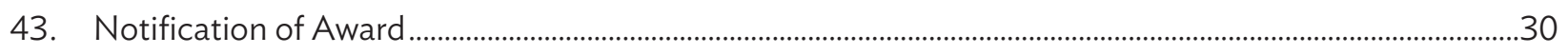

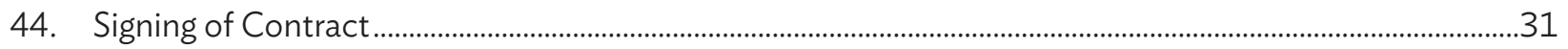

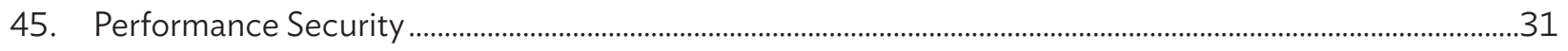

46. Bidding-Related Complaints ............................................................................................................................... 
A. General

1. Scope of Bid

2. Source of Funds

\section{Fraud and Corruption}

1.1 In connection with the Invitation for Bids (IFB) indicated in the Bid Data Sheet (BDS), the Purchaser, as indicated in the BDS, issues this Bidding Document for the supply of Goods and Related Services incidental thereto as specified in Section 6 (Schedule of Supply). The name, identification, and number of lots of the open competitive bidding (OCB) are provided in the BDS.

1.2 Throughout this Bidding Document,

(a) the term "in writing" means communicated in written form and delivered against receipt;

(b) except where the context requires otherwise, words indicating the singular also include the plural and words indicating the plural also include the singular; and

(c) "day" means calendar day.

2.1 The Borrower or Recipient (hereinafter called "Borrower") indicated in the BDS has applied for or received financing (hereinafter called "funds") from the Asian Development Bank (hereinafter called "ADB") toward the cost of the project named in the BDS. The Borrower intends to apply a portion of the funds to eligible payments under the contract(s) for which this Bidding Document is issued.

2.2 Payments by ADB will be made only at the request of the Borrower and upon approval by $A D B$ in accordance with the terms and conditions of the Financing Agreement between the Borrower and ADB (hereinafter called the Financing Agreement), and will be subject in all respects to the terms and conditions of that Financing Agreement. No party other than the Borrower shall derive any rights from the Financing Agreement or have any claim to the funds.

3.1 ADB requires Borrowers (including beneficiaries of $A D B$-financed activity) and their personnel, as well as firms and individuals participating in an ADB-financed activity, including but not limited to, Bidders, Suppliers, and Contractors, agents, subcontractors, subconsultants, service providers, subsuppliers, manufacturers (including their respective officers, directors, employees and personnel) under ADB-financed contracts to observe the highest standard of ethics during the procurement and execution of such contracts in accordance with ADB's Anticorruption Policy (1998, as amended from time to time). In pursuance of this policy, ADB

(a) defines, for the purposes of this provision, the terms set forth below as follows:

(i) "corrupt practice" means the offering, giving, receiving, or soliciting, directly or indirectly, anything of value to influence improperly the actions of another party;

(ii) "fraudulent practice" means any act or omission, including a misrepresentation, that knowingly or recklessly misleads, or attempts to mislead, a party to obtain a financial or other benefit or to avoid an obligation; 
(iii) "coercive practice" means impairing or harming, or threatening to impair or harm, directly or indirectly, any party or the property of the party to influence improperly the actions of a party;

(iv) "collusive practice" means an arrangement between two or more parties designed to achieve an improper purpose, including influencing improperly the actions of another party;

(v) "abuse" means theft, waste, or improper use of assets related to ADB-related activity, either committed intentionally or through reckless disregard;

(vi) "conflict of interest" means any situation in which a party has interests that could improperly influence that party's performance of official duties or responsibilities, contractual obligations, or compliance with applicable laws and regulations; and

(vii) "integrity violation" is any act, as defined under ADB's Integrity Principles and Guidelines (2015, as amended from time to time), which violates ADB's Anticorruption Policy, including (i) to (vi) above and the following: obstructive practice, violations of ADB sanctions, retaliation against whistleblowers or witnesses, and other violations of ADB's Anticorruption Policy, including failure to adhere to the highest ethical standard.

(b) will reject a proposal for award if it determines that the Bidder recommended for award or any of its officers, directors, employees, personnel, subconsultants, subcontractors, service providers, suppliers or manufacturers has, directly or through an agent, engaged in corrupt, fraudulent, collusive, coercive, or obstructive practices or other integrity violations in competing for the Contract;

(c) will cancel the portion of the financing allocated to a contract if it determines at any time that representatives of the Borrower or of a beneficiary of ADB-financing engaged in corrupt, fraudulent, collusive, coercive, or obstructive practices or other integrity violations during the procurement or the execution of that contract, without the Borrower having taken timely and appropriate action satisfactory to ADB to remedy the situation, including by failing to inform $A D B$ in a timely manner at the time they knew of the integrity violations;

(d) will impose remedial actions on a firm or an individual, at any time, in accordance with ADB's Anticorruption Policy and Integrity Principles and Guidelines, including declaring ineligible, either indefinitely or for a stated period of time, to participate ${ }^{1}$ in ADB-financed, -administered, or -supported activities or to benefit from an ADB-financed,-administered, or -supported contract, financially or otherwise, if it at any time determines that the firm or individual has, directly or through an agent, engaged in corrupt, fraudulent, collusive, coercive, or obstructive practices or other integrity violations; and

1 Whether as a Contractor, Subcontractor, Consultant, Manufacturer, or Supplier, or Service Provider; or in any other capacity (different names are used depending on the particular Bidding Document). 
(e) will have the right to require that a provision be included in bidding documents and in contracts financed, administered, or supported by $A D B$, requiring Bidders, suppliers, and contractors, consultants, manufacturers, service providers and other third parties engaged or involved in ADB-related activities, and their respective officers, directors, employees and personnel, to permit ADB or its representative to inspect the site and their assets, accounts and records and other documents relating to the bid submission and contract performance and to have them audited by auditors appointed by ADB.

3.2 All Bidders, consultants, contractors, suppliers, manufacturers, service providers, and other third parties engaged or involved in ADB-related activities, and their respective officers, directors, employees and personnel, are obliged to cooperate fully in any investigation when requested by $A D B$ to do so. As determined on a case by case basis by $A D B$, such cooperation includes, but is not limited to, the following:

(a) being available to be interviewed and replying fully and truthfully to all questions asked;

(b) providing ADB with any items requested that are within the party's control including, but not limited to, documents and other physical objects;

(c) upon written request by $A D B$, authorizing other related entities to release directly to ADB such information that is specifically and materially related, directly or indirectly, to the said entities or issues which are the subject of the investigation;

(d) cooperating with all reasonable requests to search or physically inspect their person and/or work areas, including files, electronic databases, and personal property used on ADB activities, or that utilizes ADB's Information and Communication Technology (ICT) resources or systems (including mobile phones, personal electronic devices, and electronic storage devices such as external disk drives);

(e) cooperating in any testing requested by ADB, including but not limited to, fingerprint identification, handwriting analysis, and physical examination and analysis; and

(f) preserving and protecting confidentiality of all information discussed with, and as required by, $\mathrm{ADB}$.

3.3 All Bidders, consultants, contractors, and suppliers shall require their officers, directors, employees, personnel, agents to ensure that, in its contracts with its subconsultants, Subcontractors and other third parties engaged or involved in ADB-related activities, such sub-consultants, Subcontractors and other third parties similarly are obliged to cooperate fully in any investigation when requested by $A D B$ to do so.

3.4 The Purchaser hereby puts the Bidder on notice that the Bidder or any Joint Venture partner of the Bidder (if any) may not be able to receive any payments under the Contract if the Bidder or any of its Joint Venture partners, as appropriate, is, or is owned (in whole or in part) by a person or entity subject to applicable sanctions.

3.5 Furthermore, Bidders shall be aware of the provision stated in Subclause 3.2 and Subclause 35.1(a) (iii) of the General Conditions of Contract. 
4. Eligible Bidders

4.1 A Bidder may be a natural person, private entity, or government-owned enterprise subject to ITB 4.5-or any combination of them with a formal intent to enter into an agreement or under an existing agreement in the form of a Joint Venture. In the case of a Joint Venture,

(a) all parties to the Joint Venture shall be jointly and severally liable; and

(b) the Joint Venture shall nominate a representative who shall have the authority to conduct all businesses for and on behalf of any and all the parties of the Joint Venture during the bidding process and, in the event the Joint Venture is awarded the Contract, during contract execution.

4.2 A Bidder, and all parties constituting the Bidder, shall have the nationality of an eligible country, in accordance with Section 5 (Eligible Countries). A Bidder shall be deemed to have the nationality of a country if the Bidder is a citizen or is constituted, incorporated, or registered, and operates in conformity with the provisions of the laws of that country. This criterion shall also apply to the determination of the nationality of proposed subcontractors or suppliers for any part of the Contract, including related services.

4.3 A Bidder shall not have a conflict of interest. All Bidders found to have a conflict of interest shall be disqualified. A Bidder may be considered to be in a conflict of interest with one or more parties in this bidding process if any of, including but not limited to, the following apply:

(a) they have controlling shareholders in common; or

(b) they receive or have received any direct or indirect subsidy from any of them; or

(c) they have the same legal representative for purposes of this Bid; or

(d) they have a relationship with each other, directly or through common third parties, that puts them in a position to have access to material information about or improperly influence the Bid of another Bidder, or influence the decisions of the Purchaser regarding this bidding process; or

(e) a Bidder participates in more than one bid in this bidding process, either individually or as a partner in a Joint Venture, except for alternative offers permitted under ITB 13. This will result in the disqualification of all Bids in which it is involved. However, subject to any finding of a conflict of interest in terms of ITB 4.3(a)-(d) above, this does not limit the participation of a Bidder as a subcontractor in another bid or of a firm as a subcontractor in more than one Bid; or

(f) a Bidder, Joint Venture partner, associates, parent company or any affiliated entity, participated as a consultant in the preparation of the design or technical specifications of the goods and services that are the subject of the Bid; or

(g) a Bidder was affiliated with a firm or entity that has been hired (or is proposed to be hired) by the Purchaser or Borrower as Project Manager for the contract; or 
(h) a Bidder would be providing goods, works, or nonconsulting services resulting from or directly related to consulting services for the preparation or implementation of the project specified in the BDS ITB 2.1 that it provided or were provided by any affiliate that directly or indirectly controls, is controlled by, or is under common control with that firm; or

(i) A Bidder that has a financial or familial relationship with staff of the Purchaser including project implementing/executing agency, or of a recipient of a part of the loan who: (i) are directly or indirectly involved in the preparation of the bidding documents or specifications of the contract, and/or the bid evaluation process of such contract; or (ii) would be involved in the implementation or supervision of such contract unless the conflict stemming from such relationship has been resolved in a manner acceptable to ADB throughout the procurement process and execution of the contract.

4.4 A firm will not be eligible to participate in any procurement activities under an ADB-financed, -administered, or -supported project while under temporary suspension or debarment by ADB pursuant to its Anticorruption Policy (see ITB 3), whether such debarment was directly imposed by $A D B$, or enforced by ADB pursuant to the Agreement for Mutual Enforcement of Debarment Decisions. A bid from a temporarily suspended or debarred firm will be rejected and such bid may be in breach of debarment conditions, thereby subject to further ADB's investigation.

4.5 Government-owned enterprises in the Purchaser's country shall be eligible only if they can establish that they (i) are legally and financially autonomous, (ii) operate under commercial law, and (iii) are not dependent agencies of the Purchaser.

4.6 A Bidder shall not be under suspension from Bidding by the Purchaser as the result of the execution of a Bid-Securing Declaration.

4.7 Bidders shall provide such evidence of their continued eligibility satisfactory to the Purchaser, as the Purchaser shall reasonably request.

4.8 Bidders shall be excluded if, by an act of compliance with a decision of the United Nations Security Council taken under Chapter VII of the Charter of the United Nations, the Borrower's country prohibits any import of goods from, or payments to, a particular country, person, or entity in respect of goods or services originating in that country. Where the Borrower's country prohibits payments to a particular person or entity or for particular goods or services by such an act of compliance, that firm shall be excluded.

5. Eligible Goods and Related Services
5.1 All Goods and Related Services to be supplied under the Contract and financed by $A D B$, shall have their country of origin in eligible source countries as defined in ITB 4.2, and all expenditures under the Contract will be limited to such Goods and Related Services.

5.2 For purposes of this clause, the term "goods" includes commodities, raw material, machinery, equipment, and industrial plants; and "related services" includes services such as insurance, transportation, installation, commissioning, training, and initial maintenance. 
5.3 The term "country of origin" means the country where the goods have been mined, grown, cultivated, produced, manufactured, or processed; or through manufacture, processing, or assembly, another commercially recognized article results that differs substantially in its basic characteristics from its imported components.

5.4 The nationality of the firm that produces, assembles, distributes, or sells the goods shall not determine their origin.

\section{B. Contents of Bidding Document}

6. Sections of the Bidding Document
6.1 The Bidding Document consists of Parts I, II, and III, which include all the sections indicated below, and should be read in conjunction with any addenda issued in accordance with ITB 8.

\section{PART I Bidding Procedures}

- Section 1 Instructions to Bidders (ITB)

- Section 2 Bid Data Sheet(BDS)

- Section 3 Evaluation and Qualification Criteria (EQC)

- Section 4 Bidding Forms (BDF)

- Section 5 Eligible Countries (ELC)

\section{PART II Supply Requirements}

- Section 6 Schedule of Supply (SS)

\section{PART III Conditions of Contract and Contract Forms}

- Section 7 General Conditions of Contract (GCC)

- Section 8 Special Conditions of Contract (SCC)

- Section 9 Contract Forms (COF)

6.2 The IFB issued by the Purchaser is not part of the Bidding Document.

6.3 The Purchaser is not responsible for the completeness of the Bidding Document and its addenda, if they were not obtained directly from the source stated by the Purchaser in the IFB.

6.4 The Bidder is expected to examine all instructions, forms, terms, and specifications in the Bidding Document. Failure to furnish all information or documentation required by the Bidding Document may result in the rejection of the Bid.

7. Clarification of Bidding Document
7.1 A prospective Bidder requiring any clarification on the Bidding Document shall contact the Purchaser in writing at the Purchaser's address indicated in the BDS. The Purchaser will respond in writing to any request for clarification, provided that such request is received no later than 21 days prior to the deadline for submission of Bids. The Purchaser shall forward copies of its response to all Bidders who have acquired the Bidding Document in accordance with ITB 6.3, including a description of the inquiry but without identifying its source. Should the Purchaser deem it necessary to amend the Bidding Document as a result of a clarification, it shall do so following the procedure under ITB 8 and ITB 24.2. 
8. Amendment of Bidding Document

\section{Preparation of Bids}

9. Cost of Bidding

10. Language of Bid

\section{Documents Comprising the Bid}

8.1 At any time prior to the deadline for submission of the Bids, the Purchaser may amend the Bidding Document by issuing addenda.

8.2 Any addendum issued shall be part of the Bidding Document and shall be communicated in writing to all who have obtained the Bidding Document directly from the Purchaser in accordance with ITB 6.3.

8.3 To give prospective Bidders reasonable time in which to take an addendum into account in preparing their Bids, the Purchaser may, at its discretion, extend the deadline for the submission of the Bids, pursuant to ITB 24.2.

9.1 The Bidder shall bear all costs associated with the preparation and submission of its Bid, and the Purchaser shall in no case be responsible or liable for those costs, regardless of the conduct or outcome of the bidding process.

10.1 The Bid, as well as all correspondence and documents relating to the Bid exchanged by the Bidder and the Purchaser, shall be written in the language specified in the BDS. Supporting documents and printed literature that are part of the Bid may be in another language provided they are accompanied by an accurate translation of the relevant passages in the language specified in the BDS, in which case, for purposes of interpretation of the Bid, such translation shall govern.

11.1 The Bid shall comprise the following:

(a) Bid Submission Sheet; and the applicable Price Schedules, in accordance with ITB 12, ITB 14, and ITB 15;

(b) Bid Security or Bid-Securing Declaration, in accordance with ITB 21;

(c) alternative Bids, if permissible, in accordance with ITB 13;

(d) written confirmation authorizing the signatory of the Bid to commit the Bidder, in accordance with ITB 22;

(e) documentary evidence in accordance with ITB 16, establishing the Bidder's eligibility to bid;

(f) documentary evidence in accordance with ITB 17, that the Goods and Related Services to be supplied by the Bidder are of eligible origin;

(g) documentary evidence in accordance with ITB 18 and ITB 31, that the Goods and Related Services conform to the Bidding Document;

(h) documentary evidence in accordance with ITB 19, establishing the Bidder's qualifications to perform the contract if its Bid is accepted; and

(i) any other document required in the BDS. 
12. Bid Submission Sheet and Price Schedules

13. Alternative Bids

14. Bid Prices and Discounts
12.1 The Bidder shall submit the Bid Submission Sheet using the form furnished in Section 4 (Bidding Forms). This form must be completed without any alterations to the text, and no substitutes shall be accepted. All blank spaces shall be filled in with the information requested.

12.2 The Bidder shall submit the Price Schedules for Goods and Related Services, according to their origin as appropriate, using the forms furnished in Section 4 (Bidding Forms) and as required in the BDS.

13.1 Unless otherwise indicated in the BDS, alternative Bids shall not be considered.

14.1 The prices and discounts quoted by the Bidder in the Bid Submission Sheet and in the Price Schedules shall conform to the requirements specified below.

14.2 All items in the Schedule of Supply must be listed and priced separately in the Price Schedules. If a Price Schedule shows items listed but not priced, their prices shall be assumed to be included in the prices of other items. Items not listed in the Price Schedule shall be assumed not to be included in the Bid, and provided that the Bid is substantially responsive, the corresponding adjustment shall be applied in accordance with ITB 32.3. Unit rates and prices for all items in the Schedule of Supply shall be expressed in positive values. If unit rates and prices are expressed in negative values, the bid will be rejected.

14.3 The price to be quoted in the Bid Submission Sheet shall be the total price of the Bid excluding any discounts offered. Absence of the total bid price in the Bid Submission Sheet may result in the rejection of the Bid.

14.4 The Bidder shall quote discounts and the methodology for their application in the Bid Submission Sheet.

14.5 The terms EXW, CIF, CIP, and other similar terms shall be governed by the rules prescribed in the current edition of Incoterms, published by the International Chamber of Commerce, at the date of the Invitation for Bids or as specified in the BDS.

14.6 Prices shall be quoted as specified in each Price Schedule included in Section 4 (Bidding Forms). The disaggregation of price components is required solely for the purpose of facilitating the comparison of Bids by the Purchaser. This shall not in any way limit the Purchaser's right to contract on any of the terms offered

(a) for Goods offered from within the Purchaser's country:

(i) the price of the goods quoted EXW (ex works, ex factory, ex warehouse, ex showroom, or off-the-shelf, as applicable), including all customs duties and sales and other taxes already paid or payable on the components and raw material used in the manufacture or assembly of goods quoted ex works or ex factory, or on the previously imported goods of foreign origin quoted ex warehouse, ex showroom, or off-the-shelf;

(ii) sales tax and all other taxes applicable in the Purchaser's country and payable on the Goods if the Contract is awarded to the Bidder; and

(iii) the total price for the item. 
(b) for Goods offered from outside the Purchaser's country:

(i) the price of the goods quoted CIF (named port of destination), or CIP (border point), or CIP (named place of destination), in the Purchaser's country, as specified in the BDS;

(ii) the price of the goods quoted FOB port of shipment (or FCA, as the case may be), if specified in the BDS; and

(iii) the total price for the item.

(c) for Related Services whenever such are specified in the Schedule of Supply:

(i) the local currency cost component of each item comprising the Related Services; and

(ii) the foreign currency cost component of each item comprising the Related Services, inclusive of all customs duties, sales, and other similar taxes applicable in the Purchaser's country, payable on the Related Services, if the Contract is awarded to the Bidder.

14.7 Prices quoted by the Bidder shall be fixed during the Bidder's performance of the Contract and not subject to variation on any account, unless otherwise specified in the BDS. A Bid submitted with an adjustable price quotation shall be treated as nonresponsive and shall be rejected, pursuant to ITB 31. If in accordance with the BDS, prices quoted by the Bidder shall be subject to adjustment during the performance of the Contract in accordance with Clause 15.2 of the General Conditions of Contract in Section 7, a Bid submitted with a fixed price will also be treated as nonresponsive and be rejected.

14.8 If so indicated pursuant to ITB 1.1, Bids are being invited for individual contracts (lots) or for any combination of contracts (packages). Unless otherwise indicated in the BDS, prices quoted shall correspond to $100 \%$ of the items specified for each lot and to $100 \%$ of the quantities specified for each item of a lot. Bidders wishing to offer any price discount for the award of more than one Contract shall specify in their bid the price discount applicable to each package, or alternatively, to individual Contracts within the package. Price discounts shall be submitted in accordance with ITB 14.4, provided the bids for all lots are submitted and opened at the same time.

\section{Currencies of Bid}

15.1 Bid prices shall be quoted in the following currencies:

(a) Bidders may express their bid price in any freely convertible currency. If a Bidder wishes to be paid in a combination of amounts in different currencies, it may quote its price accordingly.

(b) If some of the expenditures for the Related Services are to be incurred in the borrowing country, such expenditures should be expressed in the Bid and will be payable in the Purchaser's currency. 
16. Documents

Establishing the Eligibility of the Bidder

17. Documents Establishing the Eligibility of the Goods and Related Services

18. Documents Establishing the Conformity of the Goods and Related Services to the Bidding Document

19. Documents Establishing the Qualifications of the Bidder
16.1 To establish their eligibility in accordance with ITB 4, Bidders shall

(a) complete the eligibility declarations in the Bid Submission Sheet, included in Section 4 (Bidding Forms); and

(b) if the Bidder is an existing or intended Joint Venture in accordance with ITB 4.1, submit a copy of the Joint Venture Agreement, or a letter of intent to enter into such an agreement. The respective document shall be signed by all legally authorized signatories of all the parties to the existing or intended Joint Venture, as appropriate.

17.1 To establish the eligibility of the Goods and Related Services, in accordance with ITB 5, Bidders shall complete the country of origin declarations in the Price Schedule Forms included in Section 4 (Bidding Forms).

18.1 To establish the conformity of the Goods and Related Services to the Bidding Document, the Bidder shall furnish as part of its Bid documentary evidence that the Goods and Related Services conform to the requirements specified in Section 6 (Schedule of Supply).

18.2 The documentary evidence may be in the form of literature, drawings, or data, and shall consist of a detailed item-by-item description of the essential technical and performance characteristics of the Goods and Related Services, demonstrating substantial responsiveness of the Goods and Related Services to those requirements, and if applicable, a statement of deviations and exceptions to the provisions of Section 6 (Schedule of Supply).

18.3 Standards for workmanship, process, material, and equipment, as well as references to brand names or catalogue numbers specified by the Purchaser in Section 6 (Schedule of Supply), are intended to be descriptive only and not restrictive. The Bidder may offer other standards of quality, brand names, and/or catalogue numbers, provided that it demonstrates, to the Purchaser's satisfaction, that the substitutions ensure substantial equivalence or are superior to those specified in Section 6 (Schedule of Supply).

19.1 The documentary evidence of the Bidder's qualifications to perform the contract, if its bid is accepted, shall establish to the Purchaser's satisfaction that the Bidder meets each of the qualification criterion specified in Section 3 (Evaluation and Qualification Criteria).

19.2 If so required in the BDS, a Bidder that does not manufacture or produce the Goods it offers to supply shall submit the Manufacturer's Authorization using the form included in Section 4 (Bidding Forms) to demonstrate that it has been duly authorized by the manufacturer or producer of the Goods to supply these Goods in the Purchaser's country.

19.3 If so required in the BDS, a Bidder that does not conduct business within the Purchaser's country shall submit evidence that it will be represented by an agent in the country equipped and able to carry out the Supplier's maintenance, repair, and spare parts-stocking obligations prescribed in the Conditions of Contract and/or Technical Specifications. 
20. Period of Validity of Bids

\section{Bid Security/ Bid-Securing Declaration}

20.1 Bids shall remain valid for the bid validity period specified in the BDS. The bid validity period starts from the date fixed for the bid submission deadline date prescribed by the Purchaser in accordance with ITB 24.1. A Bid valid for a shorter period shall be rejected by the Purchaser as nonresponsive.

20.2 In exceptional circumstances, prior to the expiration of the bid validity period, the Purchaser may request Bidders to extend the period of validity of their Bids. The request and the responses shall be made in writing. If a Bid Security is requested in accordance with ITB 21 , it shall also be extended 28 days beyond the deadline of the extended bid validity period. A Bidder may refuse the request without forfeiting its Bid Security. A Bidder granting the request shall not be required or permitted to modify its Bid.

21.1 Unless otherwise specified in the BDS, the Bidder shall furnish as part of its Bid, in original form, either a Bid-Securing Declaration or a bid security as specified in the BDS. In the case of a bid security, the amount and currency shall be as specified in the BDS.

21.2 If a Bid-Securing Declaration is required pursuant to ITB 21.1, it shall use the form included in Section 4 (Bidding Forms). The Purchaser will declare a Bidder ineligible to be awarded a Contract for a specified period of time, as indicated in the BDS, if a Bid-Securing Declaration is executed.

21.3 If a bid security is specified pursuant to ITB 21.1, the bid security shall be, at the Bidder's option, in any of the following forms:

(a) an unconditional bank guarantee (hard copy of the bank guarantee or in the form of SWIFT message MT760), or

(b) an irrevocable letter of credit, or

(c) a cashier's or certified check.

all from a reputable source from an eligible country as described in Section 5 (Eligible Countries). In the case of a bank guarantee, the bid security shall be submitted either using the Bid Security Form included in Section 4 (Bidding Forms) or another form acceptable to the Purchaser. The form must include the complete name of the Bidder. The bid security shall be valid for 28 days beyond the original validity period of the bid, or beyond any period of extension if requested under ITB 20.2.

21.4 Unless otherwise specified in the BDS, any bid not accompanied by a substantially compliant bid security or Bid-Securing Declaration, if one is required in accordance with ITB 21.1, shall be rejected by the Purchaser as nonresponsive.

21.5 If a bid security is specified pursuant to ITB 21.1, the bid security of unsuccessful Bidders shall be returned promptly upon the successful Bidder's furnishing of the performance security pursuant to ITB 45.

21.6 If a bid security is specified pursuant to ITB 21.1, the bid security of the successful Bidder shall be returned promptly once the successful Bidder has signed the Contract Agreement and furnished the required performance security. 
21.7 The bid security may be forfeited or the Bid-Securing Declaration executed, if

(a) notwithstanding ITB 26.3, a Bidder withdraws its bid during the period of bid validity specified by the Bidder on the Bid Submission Sheet, except as provided in ITB 20.2; or

(b) the successful Bidder fails to

(i) sign the Contract Agreement in accordance with ITB 44;

(ii) furnish a performance security in accordance with ITB 45; or

(iii) accept the arithmetical corrections of its bid in accordance with ITB 33.

21.8 If the bid security is required as per ITB 21.1, the bid security of a Joint Venture shall be in the name of the Joint Venture that submits the Bid. If the Joint Venture has not been legally constituted at the time of bidding, the bid security shall be in the name of any or all of the Joint Venture partners. If the Bid-Securing Declaration is required as per ITB 21.1, the Bid-Securing Declaration of a Joint Venture shall be in the name of the Joint Venture that submits the Bid. If the Joint Venture has not been legally constituted at the time of bidding, the Bid-Securing Declaration shall be in the names of all future partners as named in the letter of intent mentioned in ITB 4.1.

22. Format and Signing of Bid
22.1 The Bidder shall prepare one original set of the documents comprising the bid as described in ITB 11 and clearly mark it "ORIGINAL." Alternative bids, if permitted in accordance with ITB 13, shall be clearly marked "ALTERNATIVE." In addition, the Bidder shall submit copies of the bid, in the number specified in the BDS, and clearly mark them "COPY." In the event of any discrepancy between the original and the copies, the original shall prevail.

22.2 The original and all copies of the Bid shall be typed or written in indelible ink and shall be signed by a person duly authorized to sign on behalf of the Bidder. This authorization shall consist of a written confirmation as specified in the BDS and shall be attached to the Bid. The name and position held by each person signing the authorization must be typed or printed below the signature. If a Bidder submits a deficient authorization, the Bid shall not be rejected in the first instance. The Purchaser shall request the Bidder to submit an acceptable authorization within the number of days as specified in the BDS. Failure to provide an acceptable authorization within the period stated in the Purchaser's request shall cause the rejection of the Bid. If either the Bid Submission Sheet or the Bid-Securing Declaration (if applicable) is not signed, the Bid shall be rejected.

22.3 Any amendments such as interlineations, erasures, or overwriting shall be valid only if they are signed or initialed by the person signing the Bid. 


\section{Submission and Opening of Bids}

\section{Sealing and Marking of Bids}

\section{Deadline for Submission of Bids}

\section{Late Bids}

\section{Withdrawal, Substitution, and Modification of Bids}

23.1 Bidders shall submit their Bids as specified in the BDS. Procedures for submission, sealing, and marking are as follows:

(a) Bidders submitting Bids by mail or by hand shall enclose the original and each copy of the Bid, including alternative Bids, if permitted in accordance with ITB 13, in separate sealed envelopes, duly marking the envelopes as "ORIGINAL," "ALTERNATIVE," and "COPY." These envelopes containing the original and the copies shall then be enclosed in one single envelope. The rest of the procedure shall be in accordance with ITB 23.2 and ITB 23.3.

(b) Bidders submitting Bids electronically shall follow the electronic bid submission procedures specified in the BDS.

23.2 The inner and outer envelopes shall

(a) bear the name and address of the Bidder;

(b) be addressed to the Purchaser in accordance with ITB 24.1;

(c) bear the specific identification of this bidding process pursuant to ITB 1.1 and any additional identification marks as specified in the BDS; and

(d) bear a warning not to open before the time and date for bid opening, in accordance with ITB 27.1.

23.3 If all envelopes are not sealed and marked as required, the Purchaser will assume no responsibility for the misplacement or premature opening of the Bid.

24.1 Bids must be received by the Purchaser at the address and no later than the date and time indicated in the BDS.

24.2 The Purchaser may, at its discretion, extend the deadline for the submission of Bids by amending the Bidding Document in accordance with ITB 8, in which case all rights and obligations of the Purchaser and Bidders previously subject to the deadline shall thereafter be subject to the deadline as extended.

25.1 The Purchaser shall not consider any Bid that arrives after the deadline for submission of Bids, in accordance with ITB 24. Any Bid received by the Purchaser after the deadline for submission of Bids shall be declared late, rejected, and returned unopened to the Bidder.

26.1 A Bidder may withdraw, substitute, or modify its Bid after it has been submitted by sending a written notice, duly signed by an authorized representative, and shall include a copy of the authorization in accordance with ITB 22.2 (except for withdrawal notices, which do not require copies). The corresponding substitution or modification of the bid must accompany the respective written notice. All notices must be

(a) prepared and submitted in accordance with ITB 22 and ITB 23 (except for withdrawal notices, which do not require copies), and in addition, the respective envelopes shall be clearly marked "WITHDRAWAL," "SUBSTITUTION," "MODIFICATION;" and 
(b) received by the Purchaser prior to the deadline prescribed for submission of bids, in accordance with ITB 24.

26.2 Bids requested to be withdrawn in accordance with ITB 26.1 shall be returned unopened to the Bidders.

26.3 No Bid may be withdrawn, substituted, or modified in the interval between the deadline for submission of bids and the expiration of the period of bid validity specified by the Bidder on the Bid Submission Sheet or any extension thereof.

\section{Bid Opening}

27.1 The Purchaser shall open the Bids in public at the address, on the date and time specified in the BDS in the presence of Bidders' designated representatives and anyone who chooses to attend. Any specific electronic bid opening procedures required, if electronic bidding is permitted in accordance with ITB 23.1, shall be as specified in the BDS.

27.2 First, envelopes marked "WITHDRAWAL" shall be opened, read out, and recorded, and the envelope containing the corresponding bid shall not be opened, but returned to the Bidder. No bid withdrawal shall be permitted unless the corresponding withdrawal notice contains a valid authorization to request the withdrawal and is read out at bid opening. Next, envelopes marked "SUBSTITUTION" shall be opened, read out, recorded, and exchanged for the corresponding Bid being substituted. The substituted Bid shall not be opened, but returned unopened to the Bidder. No bid substitution shall be permitted unless the corresponding substitution notice contains a valid authorization to request the substitution and is read out and recorded at bid opening. Envelopes marked "MODIFICATION" shall be opened, read out, and recorded with the corresponding Bid. No bid modification shall be permitted unless the corresponding modification notice contains a valid authorization to request the modification and is read out and recorded at bid opening. Only envelopes that are opened, read out, and recorded at bid opening shall be considered further.

27.3 All other envelopes shall be opened one at a time, reading out the name of the Bidder and whether there is a modification; the Bid Prices (per lot if applicable), discounts, and alternative offers; the presence of a bid security or a Bid-Securing Declaration, if required; and any other details as the Purchaser may consider appropriate. Only discounts and alternative offers read out and recorded at bid opening shall be considered for evaluation. Unless otherwise specified in the BDS, all pages of the Bid Submission Sheet and Price Schedules are to be initialed by at least three representatives of the Purchaser attending the bid opening. No Bid shall be rejected at bid opening except for late Bids, in accordance with ITB 25.1.

27.4 The Purchaser shall prepare a record of the bid opening that shall include, as a minimum: the name of the Bidder and whether there is a withdrawal, substitution, or modification; the Bid Price, per lot if applicable, any discounts, and alternative offers if they were permitted; and the presence or absence of a bid security or Bid-Securing Declaration, if one was required. The Bidders' representatives who are present shall be requested to sign the record. The omission of a Bidder's signature on the record shall not invalidate the contents and effect of the record. A copy of the record shall be distributed to all Bidders who submitted Bids on time, and posted online if electronic bidding was permitted. 


\section{E. Evaluation and Comparison of Bids}

28. Confidentiality

\section{Clarification of Bids}

30. Deviations, Reservations, and Omissions

31. Determination of Responsiveness
28.1 Information relating to the examination, evaluation, comparison, and postqualification of Bids, and recommendation of contract award, shall not be disclosed to Bidders or any other persons not officially concerned with such process until the publication of Contract award.

28.2 Any attempt by a Bidder to influence the Purchaser in the examination, evaluation, comparison, and postqualification of the Bids or Contract award decisions may result in the rejection of its Bid.

28.3 Notwithstanding ITB 28.2, from the time of bid opening to the time of Contract award, if any Bidder wishes to contact the Purchaser on any matter related to the bidding process, it should do so in writing.

29.1 To assist in the examination, evaluation, comparison, and postqualification of the bids, the Purchaser may, at its discretion, ask any Bidder for a clarification of its bid. Any clarification submitted by a Bidder with regard to its bid and that is not in response to a request by the Purchaser shall not be considered. The Purchaser's request for clarification and the response shall be in writing. No change in the prices or substance of the bid shall be sought, offered, or permitted, except to confirm the correction of arithmetic errors discovered by the Purchaser in the evaluation of the bids, in accordance with ITB 33.

29.2 If a Bidder does not provide clarifications on its Bid by the date and time set in the Purchaser's request for clarification, its bid may be rejected.

30.1 During the evaluation of Bids, the following definitions apply:

(a) "Deviation" is a departure from the requirements specified in the Bidding Document;

(b) "Reservation" is the setting of limiting conditions or withholding from complete acceptance of the requirements specified in the Bidding Document; and

(c) "Omission" is the failure to submit part or all of the information or documentation required in the Bidding Document.

31.1 The Purchaser's determination of a bid's responsiveness is to be based on the contents of the bid itself, as defined in ITB 11.

31.2 A substantially responsive bid is one that meets the requirements of the Bidding Document without material deviation, reservation, or omission. A material deviation, reservation, or omission is one that,

(a) if accepted, would

(i) affect in any substantial way the scope, quality, or performance of the Goods and Related Services specified in Section 6 (Schedule of Supply); or 
(ii) limits in any substantial way, inconsistent with the Bidding Document, the Purchaser's rights or the Bidder's obligations under the proposed Contract; or

(b) if rectified, would unfairly affect the competitive position of other Bidders presenting substantially responsive bids.

31.3 The Purchaser shall examine the technical aspects of the Bids in particular, to confirm that all requirements of Section 6 (Schedule of Supply) have been met without any material deviation, reservation, or omission.

31.4 If a Bid is not substantially responsive to the requirements of the Bidding Document, it shall be rejected by the Purchaser and may not subsequently be made responsive by correction of the material deviation, reservation, or omission.

32. Nonmaterial Nonconformities

33. Correction of Arithmetical Errors
32.1 Provided that a Bid is substantially responsive, the Purchaser may waive nonconformities in the bid that do not constitute a material deviation, reservation, or omission.

32.2 Provided that a Bid is substantially responsive, the Purchaser may request that the Bidder submit the necessary information or documentation, within a reasonable period of time, to rectify nonmaterial nonconformities or omissions in the Bid related to documentation requirements. Requesting information or documentation on such nonconformities shall not be related to any aspect of the price of the Bid. Failure of the Bidder to comply with the request may result in the rejection of its Bid.

32.3 Provided that a Bid is substantially responsive, the Purchaser shall rectify quantifiable nonmaterial nonconformities or omissions related to the Bid Price. To this effect, the Bid Price shall be adjusted, for comparison purposes only, to reflect the price of the missing or nonconforming item or component. The adjustment shall be made using the method indicated in Section 3 (Evaluation and Qualification Criteria).

33.1 Provided that the Bid is substantially responsive, the Purchaser shall correct arithmetical errors on the following basis:

(a) If there is a discrepancy between the unit price and the total price that is obtained by multiplying the unit price and quantity, the unit price shall prevail and the total price shall be corrected, unless in the opinion of the Purchaser there is an obvious misplacement of the decimal point in the unit price, in which case the total price as quoted shall govern and the unit price shall be corrected.

(b) If there is an error in a total corresponding to the addition or subtraction of subtotals, the subtotals shall prevail and the total shall be corrected.

(c) If there is a discrepancy between words and figures, the amount in words shall prevail, unless the amount expressed in words is related to an arithmetic error, in which case the amount in figures shall prevail subject to (a) and (b) above. 
33.2 If the Bidder that submitted the lowest evaluated Bid does not accept the correction of errors, its Bid shall be rejected and its bid security may be forfeited, or its Bid-Securing Declaration executed.

34. Conversion to Single Currency

35. Domestic Preference

36. Evaluation and Comparison of Bids
34.1 For evaluation and comparison purposes, the currency(ies) of the Bid shall be converted into a single currency as specified in the BDS.

35.1 Unless otherwise specified in the BDS, domestic preference shall not apply.

36.1 The Purchaser shall use the criteria and methodologies indicated in this clause. No other criteria or methodologies shall be permitted.

36.2 To evaluate a bid, the Purchaser shall consider the following:

(a) the bid price as quoted in accordance with ITB 14;

(b) price adjustment for correction of arithmetic errors in accordance with ITB 33.1;

(c) price adjustment due to discounts offered in accordance with ITB 14.4;

(d) adjustment for nonmaterial nonconformities in accordance with ITB 32.3;

(e) assessment whether the bid is abnormally low in accordance with ITB 37; and

(f) price adjustment due to application of the evaluation criteria specified in Section 3 (Evaluation and Qualification Criteria). These criteria may include factors related to the characteristics, performance, and terms and conditions of purchase of the Goods and Related Services, which shall be expressed to the extent practicable in monetary terms to facilitate comparison of bids unless otherwise specified in Section 3; and

(g) converting the amount resulting from applying (a) to (d) above, if relevant, to a single currency in accordance with ITB 34.

36.3 The Purchaser's evaluation of a bid will exclude and not take into account,

(a) in the case of Goods offered from within the Purchaser's country, all sales tax and all other taxes, applicable in the Purchaser's country and payable on the Goods if the Contract is awarded to the Bidder;

(d) in the case of Goods offered from outside the Purchaser's country, all customs duties, sales tax, and other taxes, applicable in the Purchaser's country and payable on the Goods if the Contract is awarded to the Bidder; and

(c) any allowance for price adjustment during the period of performance of the Contract, if provided in the Bid. 
36.4 If the Bidding Document allows Bidders to quote separate prices for different lots (contracts), and the award to a single Bidder of multiple lots (contracts), the methodology to determine the lowest evaluated price of the lot (contract) combinations, including any discounts offered in the Bid Submission Sheet, is specified in Section 3 (Evaluation and Qualification Criteria).

36.5 The Purchaser shall compare all substantially responsive Bids to determine the lowest evaluated bid, in accordance with ITB 36.2.

\section{Abnormally Low Bids}

37.1 An abnormally low bid is one where the bid price, in combination with other elements of the bid, appears to be so low that it raises concerns as to the capability of the Bidder to perform the contract for the offered bid price.

37.2 When the offered bid price appears to be abnormally low, the Purchaser shall undertake a three-step review process as follows:

(a) identify abnormally low costs and unit rates by comparing them with the engineer's estimates, other substantially responsive bids, or recently awarded similar contracts;

(b) clarify and analyze the bidder's resource inputs and pricing, including overheads, contingencies and profit margins; and

(c) decide whether to accept or reject the bid.

37.3 With regard to ITB 37.2 (b) above, the Purchaser will seek a written explanation from the bidder of the reasons for the offered bid price, including a detailed analysis of costs and unit prices, by reference to the scope, proposed methodology, schedule, and allocation of risks and responsibilities. This may also include information regarding the economy of the manufacturing process; the services to be provided, or the construction method to be used; the technical solutions to be adopted; and any exceptionally favorable conditions available to the bidder for the works, equipment or services proposed.

37.4 After examining the explanation given and the detailed price analyses presented by the bidder, the Purchaser may:

(a) accept the bid, if the evidence provided satisfactorily accounts for the low bid price and costs, in which case the bid is not considered abnormally low;

(b) accept the bid, but require that the amount of the performance security be increased at the expense of the bidder to a level sufficient to protect the Purchaser against financial loss. The amount of the performance security shall generally be not more than $20 \%$ of the contract price; or

(c) reject the bid if the evidence provided does not satisfactorily account for the low bid price, and make a similar determination for the next ranked bid, if required. 
38. Postqualification of the Bidder

39. Purchaser's Right to Accept Any Bid, and to Reject Any or All Bids

40. Notice of Intention for Award of Contract

38.1 The Purchaser shall determine to its satisfaction whether the Bidder that is selected as having submitted the lowest evaluated and substantially responsive Bid is qualified to perform the Contract satisfactorily.

38.2 The determination shall be based upon an examination of the documentary evidence of the Bidder's qualifications submitted by the Bidder, pursuant to ITB 19. Unless permitted in the BDS, the determination shall not take into consideration the qualifications of other firms such as the Bidder's subsidiaries, parent entities, or affiliates.

38.3 An affirmative determination shall be a prerequisite for award of the Contract to the Bidder. The Purchaser reserves the right to reject the bid of any bidder found to be in circumstances described in GCC 35.2. A negative determination shall result in disqualification of the Bid, in which event the Purchaser shall proceed to the next lowest evaluated Bid to make a similar determination of that Bidder's capabilities to perform satisfactorily.

39.1 The Purchaser reserves the right to accept or reject any Bid, and to annul the bidding process and reject all bids at any time prior to Contract award, without thereby incurring any liability to the Bidders. In case of annulment, all Bids submitted and specifically, bid securities, shall be promptly returned to the Bidders.

40.1 If Standstill provisions apply as specified in the BDS, the standstill period shall be defined in the BDS to specify the duration subsequent to notification of intention for award of contract (before making the actual contract award) within which any unsuccessful bidder can challenge the proposed award.

\section{F. Award of Contract}

\section{Award Criteria}

42. Purchaser's Right to Vary Quantities at Time of Award

\section{Notification of Award}

41.1 The Purchaser shall award the Contract to the Bidder whose offer has been determined in line with ITB 36 to ITB 38 above to be the lowest evaluated bid and is substantially responsive to the Bidding Document, provided further that the Bidder is determined to be qualified to perform the Contract satisfactorily.

42.1 At the time the Contract is awarded, the Purchaser reserves the right to increase or decrease the quantity of Goods and Related Services originally specified in Section 6 (Schedule of Supply), provided this does not exceed the percentages indicated in the BDS, and without any change in the unit prices or other terms and conditions of the Bid and the Bidding Document.

43.1 Prior to the expiration of the period of bid validity and upon expiry of the standstill period specified in ITB 40.1, or upon satisfactory resolution of a complaint filed within standstill period, if applicable, the Purchaser shall transmit the Notification of Award using the form included in Section 9 (Contract Forms) to the successful Bidder, in writing, that its Bid has been accepted. At the same time, the Purchaser shall also notify all other Bidders of the results of the bidding. 
43.2 Unless standstill period applies, upon notification of award, unsuccessful Bidders may request in writing to the Purchaser for a debriefing seeking explanations on the grounds on which their Bids were not selected. The Purchaser shall promptly respond in writing and/or in a debriefing meeting to any unsuccessful Bidder who, after publication of contract award, requests a debriefing.

43.3 Until a formal contract is prepared and executed, the notification of award shall constitute a binding Contract.

43.4 Within 2 weeks of the award of contract or expiry of the standstill period, where such period applies, or, if a complaint has been filed within the standstill period, upon receipt of ADB's confirmation of satisfactory resolution of the complaint, the Borrower shall publish in an English language newspaper or widely known and freely accessible website the results identifying the bid and lot or package numbers, as applicable and the following information:

(a) name of each Bidder who submitted a Bid;

(b) bid prices as read out at bid opening;

(c) name and evaluated prices of each Bid that was evaluated;

(d) name of Bidders whose Bids were rejected and the reasons for their rejection; and

(e) name of the winning Bidder, and the price it offered, as well as the duration and summary scope of the contract awarded.

\section{Signing of Contract}

\section{Performance Security}

44.1 Promptly after notification, the Purchaser shall send to the successful Bidder the Contract Agreement.

44.2 Within 28 days of receipt of the Contract Agreement, the successful Bidder shall sign, date, and return it to the Purchaser.

45.1 Within 28 days of the receipt of notification of award from the Purchaser, the successful Bidder shall furnish the Performance Security in accordance with the GCC, subject to ITB 37, using for that purpose the Performance Security Form included in Section 9 (Contract Forms), or another form acceptable to the Purchaser. If the bank issuing performance security is located outside the Purchaser's country, it shall be counter-guaranteed or encashable by a bank in the Purchaser's country.

45.2 Failure of the successful Bidder to submit the abovementioned performance security or sign the Contract Agreement shall constitute sufficient grounds for the annulment of the award and forfeiture of the bid security or execution of the Bid-Securing Declaration. In that event, the Purchaser may award the Contract to the next lowest evaluated Bidder whose offer is substantially responsive and is determined by the Purchaser to be qualified to perform the Contract satisfactorily.

46.1 The procedures for dealing with Bidding-Related Complaints arising out of this bidding process are specified in the BDS. 


\section{Section 2: Bid Data Sheet}

The Bid Data Sheet (BDS) contains information and provisions that are specific to a particular bidding process. The Purchaser must specify in the BDS only information that the Instructions to Bidders (ITB) request be specified in the BDS. All information shall be provided, and no clause shall be left blank.

To facilitate the preparation of the BDS, its clauses are numbered with the same numbers as the corresponding ITB clauses. This guide provides information to the Purchaser on how to enter all required information, and includes a BDS format that summarizes all information to be provided.

\section{A. General}

\begin{tabular}{|c|c|}
\hline ITB 1.1 & The number of the Invitation for Bids (IFB) is: [insert identification number of the IFB] \\
\hline ITB 1.1 & The Purchaser is: [insert name of the purchaser] \\
\hline ITB 1.1 & $\begin{array}{l}\text { The name of the open competitive bidding }(O C B) \text { is: [insert the name of } O C B] \\
\text { The identification number of the } O C B \text { is: [insert identification number of the } O C B] \\
\text { The number and identification of lots comprising this } O C B \text { is: [if there are no lots, insert "None." If there } \\
\text { are lots, insert a list of lots, identifying each lot by number and title] }\end{array}$ \\
\hline ITB 2.1 & The Borrower is: [insert name of the borrower] \\
\hline ITB 2.1 & The name of the Project is: [insert name of the project] \\
\hline
\end{tabular}

\section{B. Contents of Bidding Document}

\begin{tabular}{|l|l}
\hline ITB 7.1 & For clarification purposes only, the Purchaser's address is: [Insert details below as appropriate] \\
Attention: [insert full name of the person, if applicable] & Street address: [insert street address and number] \\
Floor/Room number: [insert floor and room number, if applicable] & City: [insert name of the city or town] \\
ZIP code: [insert postal (ZIP) code, if applicable] \\
Country: [insert name of country] \\
Telephone: [insert telephone number including country and city codes] \\
Fax: [insert fax number with country and city codes] \\
E-mail: [insert e-mail address, if applicable]
\end{tabular}




\section{Preparation of Bids}

\begin{tabular}{|c|c|}
\hline ITB 10.1 & The language of the Bid is: [insert "English"] \\
\hline ITB 11.1(i) & $\begin{array}{l}\text { The Bidder shall submit with its Bid the following additional documents: [insert type of any additional } \\
\text { documents not already listed in ITB } 11.1 \text { that must be submitted with the bid] }\end{array}$ \\
\hline ITB 12.2 & $\begin{array}{l}\text { The units and rates in figures entered into the Price Schedules should be typewritten or if written } \\
\text { by hand, must be in print form. Price Schedules not presented accordingly may be considered } \\
\text { nonresponsive. }\end{array}$ \\
\hline ITB 13.1 & $\begin{array}{l}\text { Alternative Bids [insert "shall" or "shall not"] be permitted } \\
\text { [If alternative bids are permitted, insert the following or revise as appropriate "Bidders may submit Alternative Bids } \\
\text { that do not conform to the specifications of Goods but meet the performance prescribed in, or the objectives of, the } \\
\text { specifications. However, only the Alternative Bids of the Bidder whose main Bid is the lowest evaluated substantially } \\
\text { responsive Bid will be considered. If a Bidder wishes to have its Alternative Bid or Bids considered on an equal basis } \\
\text { with all other main Bids, it shall submit a separate Bid Security or Bid-Securing Declaration for each Alternative Bid. } \\
\text { All Alternative Bids submitted in this manner will be treated as main Bids. Alternative Bids must be submitted in a } \\
\text { sealed envelope clearly marked "Alternative Bid", separate from the main Bid."] }\end{array}$ \\
\hline ITB 14.5 & The Incoterms edition is: [insert incoterm edition] \\
\hline ITB 14.6(b)(i) & $\begin{array}{l}\text { For Goods offered from outside the Purchaser's country, the Bidder shall quote prices using the } \\
\text { following Incoterms: }\end{array}$ \\
\hline ITB 14.6(b)(ii) & $\begin{array}{l}\text { In addition to the above, the Bidder shall quote prices for Goods offered from outside the Purchaser's } \\
\text { country using the following Incoterms: } \\
\text { [Only if the Purchaser wishes to reserve transportation and insurance to domestic companies or other designated } \\
\text { sources, insert: "FOB (...named port of shipment)" if CIF was specified under ITB 14.6(b)(i) above or "FCA (... } \\
\text { named place)" if CIP was specified under ITB 14.6(b)(i) above. However, identification of the lowest evaluated bid } \\
\text { must be on the basis of the CIF or CIP price, but the Purchaser may sign the contract on FOB or FCA terms and make } \\
\text { its own arrangement for transportation and/or insurance.] }\end{array}$ \\
\hline ITB 14.7 & $\begin{array}{l}\text { The prices quoted by the Bidder [insert "shall" or "shall not"] be adjustable. } \\
\text { [If prices are to be adjustable, insert "The formula for adjusting the prices and explanatory details are specified in the } \\
\text { SCC Clause 15.2. Bidder shall fill out the Tables of Adjustment Data in Section } 4 \text { (Bidding Forms)."] } \\
\text { [Use "Adjustable" where the contract period is of long duration (generally exceeds } 18 \text { months). Prices payable to the } \\
\text { contractor shall be subject to price adjustment during the performance of the contract.] } \\
\text { [If prices shall not be adjustable, the Tables of Adjustment Data in Section } 4 \text { (Bidding Forms) shall be removed] }\end{array}$ \\
\hline ITB 14.8 & $\begin{array}{l}\text { Prices quoted for each lot shall correspond at least to [insert figure] \% of the items specified for each } \\
\text { lot. } \\
\text { Prices quoted for each item of a lot shall correspond at least to [insert figure] \% of the quantities } \\
\text { specified for this item of a lot. }\end{array}$ \\
\hline ITB 19.2 & $\begin{array}{l}\text { The Bidder shall include with its bid the Manufacturer's Authorization for the following item(s): } \\
\text { [Insert the list, which should include only critical items] } \\
\text { The Bidder is required to submit documentation to substantiate that it is an authorized dealer, } \\
\text { distributor, or reseller of the goods being procured. }\end{array}$ \\
\hline
\end{tabular}




\begin{tabular}{|c|c|}
\hline ITB 19.3 & $\begin{array}{l}\text { The Bidder [insert "is" or "is not"] required to include with its bid, evidence that it will be represented } \\
\text { by an Agent in the Purchaser's country. }\end{array}$ \\
\hline ITB 20.1 & $\begin{array}{l}\text { The bid validity period shall be [insert number of days] days. } \\
\text { [The period should be sufficient to permit completion of evaluation and comparison of bids, review of the } \\
\text { recommended selection by ADB (if so required), acquire all necessary approvals, and notify the successful bidder of } \\
\text { the award. Normally, the bid validity period should be } 90 \text { days. For procurement of commodities, validity could, in } \\
\text { appropriate cases, be shorter. A realistic period should be specified.] }\end{array}$ \\
\hline ITB 21.1 & $\begin{array}{l}\text { [Choose one of the following options as appropriate] } \\
\text { Neither a bid security nor a Bid-Securing Declaration is required. } \\
\text { [or] } \\
\text { The Bidder shall furnish a bid security in the amount of [insert amount and currency. The amount of the } \\
\text { bid security should be stated as a fixed amount, normally computed as 1\% to 2\% of the estimated contract value. } \\
\text { The amount may be reduced for very large contracts.] } \\
\text { [or] } \\
\text { The Bidder shall furnish a Bid-Securing Declaration. }\end{array}$ \\
\hline ITB 21.2 & The ineligibility period will be [insert number of years] \\
\hline ITB 21.4 & $\begin{array}{l}\text { [Choose one of the following options as appropriate.] } \\
\text { No further instruction. } \\
\text { [or] } \\
\text { Subject to the succeeding sentences, any bid not accompanied by an irrevocable and callable bid } \\
\text { security shall be rejected by the Purchaser as nonresponsive. If a Bidder submits a bid security } \\
\text { that (i) deviates in form, amount, and/or period of validity, or (ii) does not provide sufficient } \\
\text { identification of the Bidder (including, without limitation, failure to indicate the name of the Joint } \\
\text { Venture or, where the Joint Venture has not yet been constituted, the names of all future Joint } \\
\text { Venture Partners), the Purchaser shall request the Bidder to submit a compliant bid security within } \\
\text { [insert number of days; generally 14 days] days of receiving such a request. Failure to provide a compliant } \\
\text { bid security within the prescribed period of receiving such a request shall cause the rejection of } \\
\text { the Bid. } \\
\text { [or] } \\
\text { Subject to the succeeding sentences, any bid not accompanied by Bid-Securing Declaration shall } \\
\text { be rejected by the Purchaser as nonresponsive. If a Bidder submits a Bid-Securing Declaration } \\
\text { that (i) deviates in form, content, and/or period of validity or (ii) does not provide sufficient } \\
\text { identification of the Bidder (including, without limitation, failure to indicate the name of the Joint } \\
\text { Venture or, where the Joint Venture has not yet been constituted, the names of all future Joint } \\
\text { Venture Partners), the Purchaser shall request the Bidder to submit a compliant Bid-Securing } \\
\text { Declaration within [insert number of days; generally } 7 \text { days] days of receiving such a request. Failure } \\
\text { to provide a compliant Bid-Securing Declaration within the prescribed period of receiving such a } \\
\text { request shall cause the rejection of the Bid. }\end{array}$ \\
\hline ITB 22.1 & In addition to the original Bid, the number of copies is: [insert number of copies required] \\
\hline
\end{tabular}




\begin{tabular}{|l|l|}
\hline ITB 22.2 & $\begin{array}{l}\text { The written confirmation of Authorization to sign on behalf of the Bidder shall consist of: } \\
\text { [insert the name and description of the documentation required to demonstrate the authority of the signatory to sign } \\
\text { the bid. Purchaser may wish to consider the following language: "An organizational document, board resolution or } \\
\text { its equivalent, or power of attorney specifying the representative's authority to sign the Bid on behalf of, and to legally } \\
\text { bind, the Bidder. If the Bidder is an intended or an existing Joint Venture, the power of attorney should be signed by } \\
\text { all partners and specify the authority of the named representative of the Joint Venture to sign on behalf of, and legally } \\
\text { bind, the intended or existing Joint Venture. If the Joint Venture has not yet been formed, also include evidence from } \\
\text { all proposed Joint Venture partners of their intent to enter into a Joint Venture in the event of a contract award in } \\
\text { accordance with ITB 16.1 (b)"] }\end{array}$ \\
\hline ITB 22.2 & $\begin{array}{l}\text { The Bidder shall submit an acceptable authorization within [insert number of days; generally } 14 \text { days] } \\
\text { days. }\end{array}$ \\
\hline
\end{tabular}

\section{Submission and Opening of Bids}

\begin{tabular}{|c|c|}
\hline ITB 23.1 & $\begin{array}{l}\text { [Choose one of the following options as appropriate.] } \\
\text { Bidders shall submit their Bids by mail or by hand. } \\
{[0 r]} \\
\text { Bidders shall submit their Bids electronically. }\end{array}$ \\
\hline ITB 23.1(b) & $\begin{array}{l}\text { Electronic bidding submission procedures shall be: [insert a description of the electronic bidding submission } \\
\text { procedures if applied in accordance with ITB } 23.1 \text { above, otherwise state "Not applicable"]. }\end{array}$ \\
\hline ITB 23.2(c) & $\begin{array}{l}\text { The additional identification marks are: [insert the name and/or number that must appear on the bid } \\
\text { envelope to identify this specific bidding process]. }\end{array}$ \\
\hline ITB 24.1 & 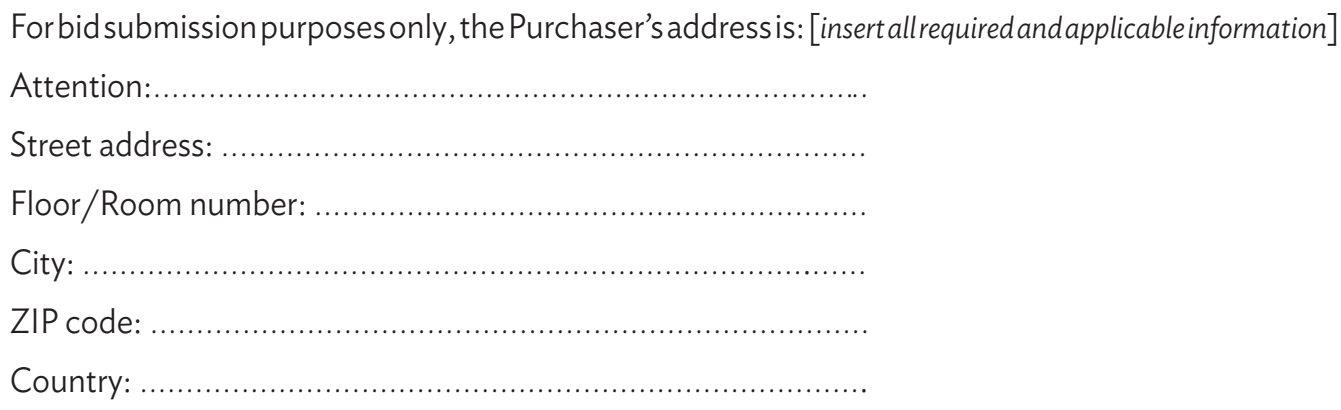 \\
\hline ITB 24.1 & 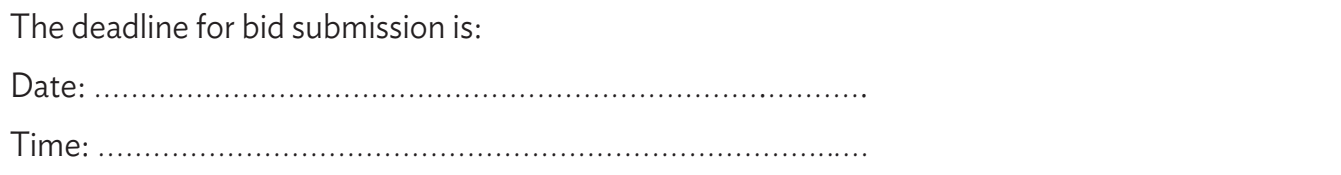 \\
\hline ITB 27.1 & 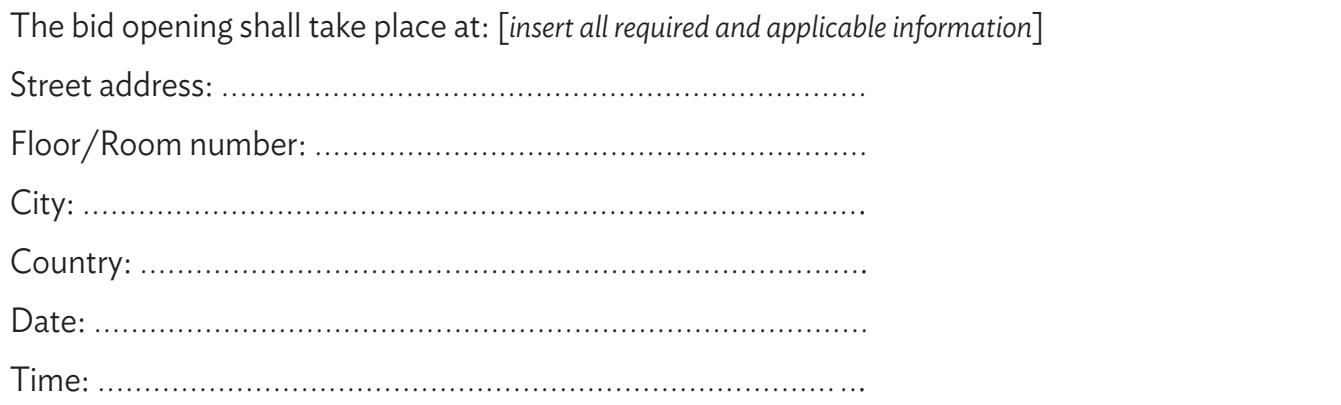 \\
\hline
\end{tabular}




\begin{tabular}{|l|l|}
\hline ITB 27.1 & $\begin{array}{l}\text { The electronic bid opening procedure shall be as follows: [if electronic bidding is permitted in accordance } \\
\text { with ITB 23.1, insert here a description of the electronic bid opening procedures; otherwise, state "not applicable"] }\end{array}$ \\
\hline ITB 27.3 & $\begin{array}{l}\text { The Bid Submission Sheet and Price Schedules shall be initialed by [insert number of initials] } \\
\text { representatives of the Purchaser attending Bid opening. }\end{array}$ \\
\hline
\end{tabular}

\section{E. Evaluation and Comparison of Bids}

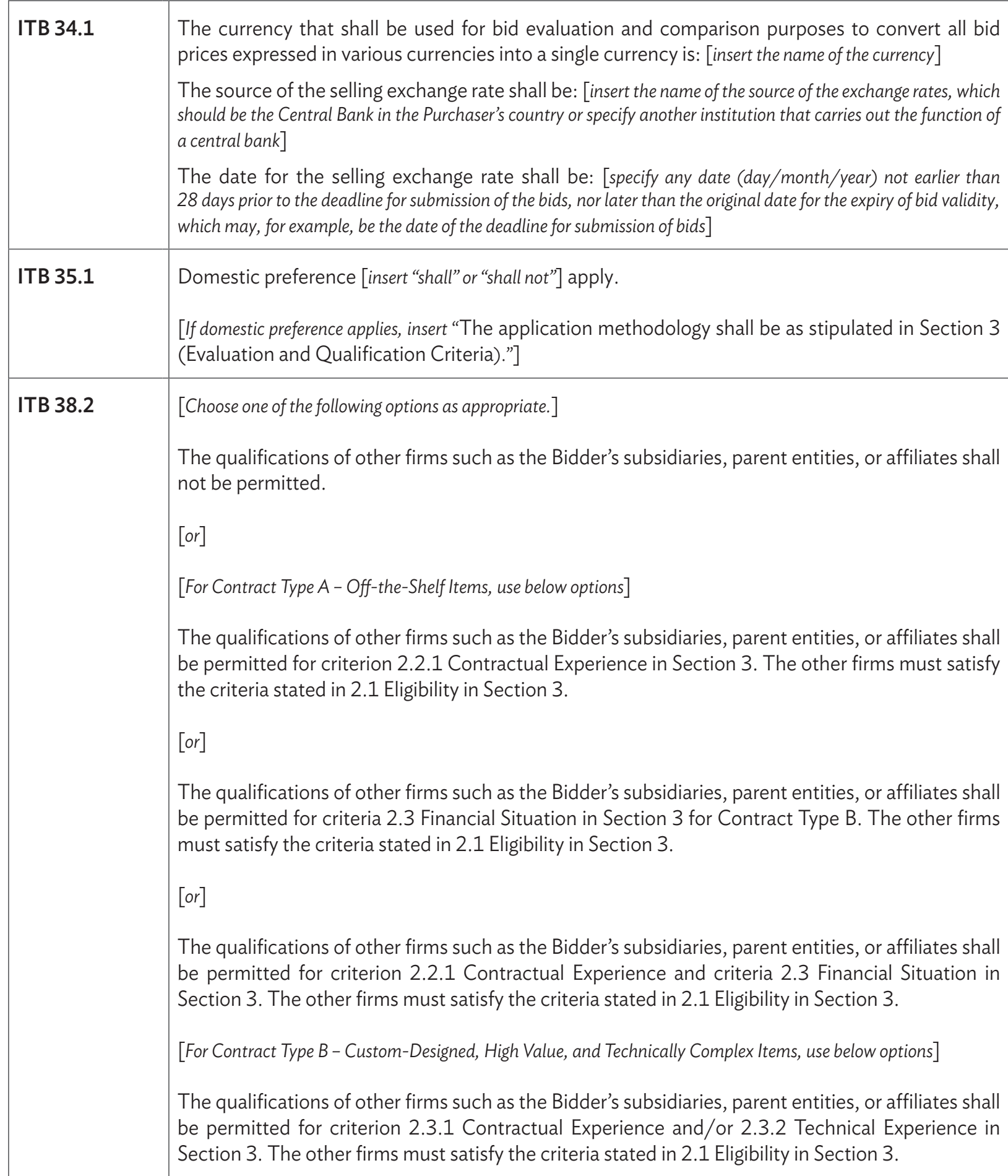




\begin{tabular}{|c|c|}
\hline & $\begin{array}{l}\text { [or] } \\
\text { The qualifications of other firms such as the Bidder's subsidiaries, parent entities, or affiliates } \\
\text { shall be permitted for criteria } 2.4 \text { Financial Situation in Section 3. The other firms must satisfy the } \\
\text { criteria stated in } 2.1 \text { Eligibility in Section } 3 \text {. } \\
\text { [or] } \\
\text { The qualifications of other firms such as the Bidder's subsidiaries, parent entities, or affiliates shall } \\
\text { be permitted for criterion 2.3.1 Contractual Experience and/or } 2.3 .2 \text { Technical Experience and } \\
\text { criteria } 2.4 \text { Financial Situation in Section 3. The other firms must satisfy the criteria stated in } 2.1 \\
\text { Eligibility in Section 3. } \\
\text { [If permitted, add "The Bidder shall provide the Affiliate Company Guarantee Form included in } \\
\text { Section } 4 \text { (Bidding Forms) filled out and signed by each subsidiary, parent entity, or affiliate that } \\
\text { the Bidder submits for consideration of the Purchaser in determining its qualifications."] }\end{array}$ \\
\hline ITB 40.1 & $\begin{array}{l}\text { [Choose one of the following options as appropriate.] } \\
\text { Standstill provisions shall not apply. } \\
\text { [or] } \\
\text { Standstill provisions shall apply. The duration of standstill period will be [insert number of days] } \\
\text { days from the date of notice of intention for award of contract. } \\
\text { The Purchaser shall, at the start of the standstill period, notify in writing each Bidder that } \\
\text { submitted a bid, of its intention to award a contract to the successful Bidder at the end of } \\
\text { standstill period. The notification using the form included in Section } 9 \text { (Contract Forms) shall } \\
\text { include the following information: } \\
\text { (a) the name of each Bidder who submitted a Bid; } \\
\text { (b) the bid prices as read out at bid opening; } \\
\text { (c) the name and evaluated prices of each Bid that was evaluated; } \\
\text { (d) the name of Bidders whose bids were rejected and the reasons for their rejection; } \\
\text { (e) the name of the winning Bidder, and the price it offered, as well as the duration and } \\
\text { summary scope of the contract awarded; and } \\
\text { (f) a statement of the reason(s) the bid of the unsuccessful Bidder to whom the notification } \\
\text { is addressed was unsuccessful, unless the price information under (e) of this paragraph } \\
\text { already reveals the reason. }\end{array}$ \\
\hline
\end{tabular}




\section{F. Award of Contract}

\begin{tabular}{|l|l|}
\hline ITB 42.1 & $\begin{array}{l}\text { The maximum percentage by which quantities may be increased is: [insert percentage] } \\
\text { The maximum percentage by which quantities may be decreased is: [insert percentage, for example, } \\
\text { 15\%] }\end{array}$ \\
\hline ITB 46.1 & $\begin{array}{l}\text { The procedures for Bidding-Related Complaints are referenced in the Procurement Regulations for } \\
\text { ADB Borrowers (Appendix 7). The Bidder should submit its complaint following these procedures, } \\
\text { in writing, to: } \\
\text { For the attention: [insert full name of person receiving complaints] } \\
\text { Title/position: [insert title/position] } \\
\text { Purchaser: [insert name of Purchaser] } \\
\text { E-mail address: [insert e-mail address] } \\
\text { Fax number: [insert fax number, delete if not used] }\end{array}$ \\
\end{tabular}




\section{Section 3: Evaluation and Qualification Criteria}

The purpose of the Evaluation and Qualification Criteria (EQC) is to specify the criteria that the Purchaser will use to evaluate the Bids and postqualify the lowest-evaluated Bidder. The Purchaser must prepare the EQC and include it as a part of the Bidding Document. The EQC is not a Contract document and, therefore, it is not a part of the Contract.

\section{Table of Criteria}

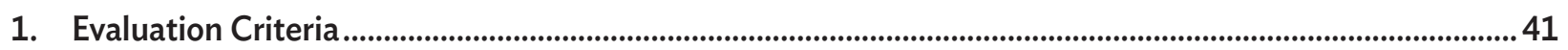

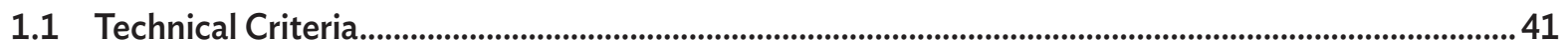

1.2 Domestic Preference ................................................................................................................................... 41

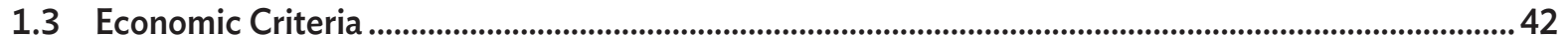

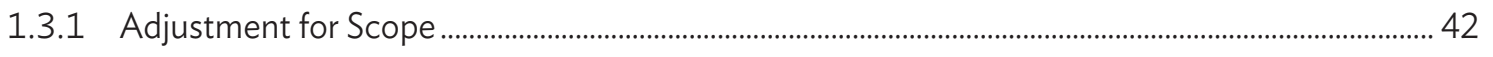

1.3.1.1 Local Handling and Inland Transportation ........................................................................ 42

1.3.1.2 Minor Omissions or Missing Items ................................................................................................ 43

1.3.2 Adjustment for Deviations from the Terms of Payment......................................................................... 43

1.3.3 Adjustment for Deviations in the Delivery and Completion Schedule .............................................. 43

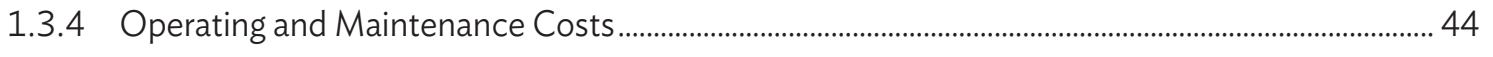

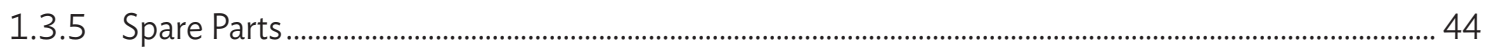

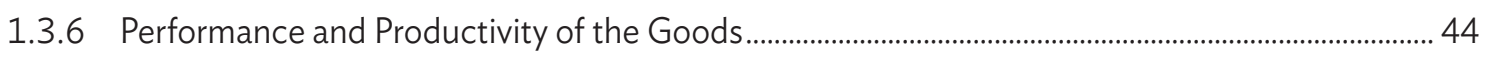

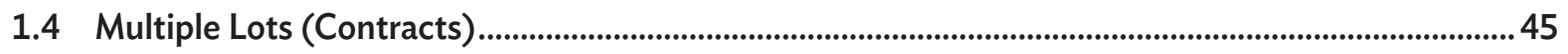

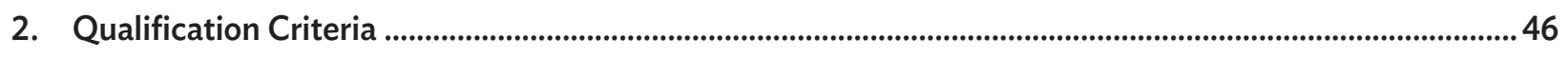

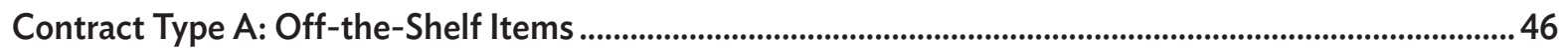

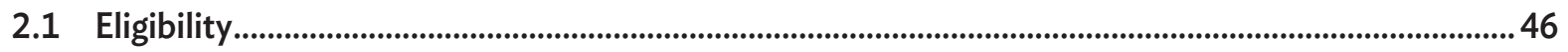

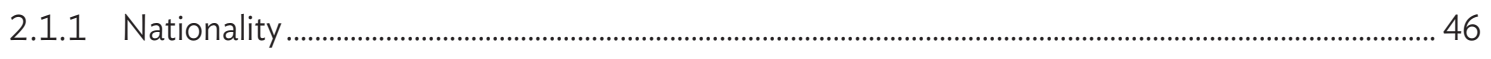

2.1.2 Conflict of Interest .............................................................................................................................................. 46 


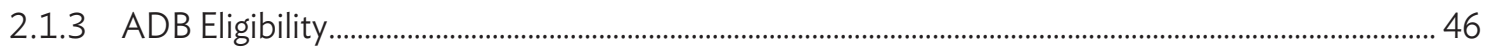

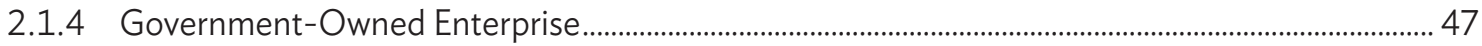

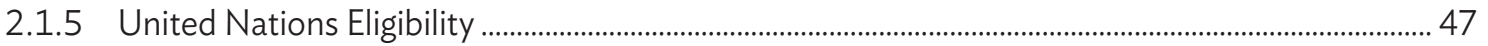

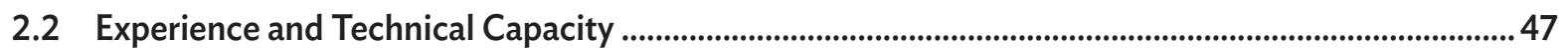

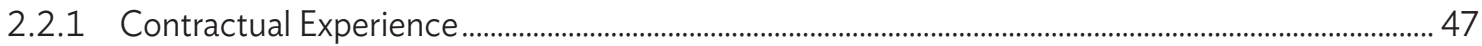

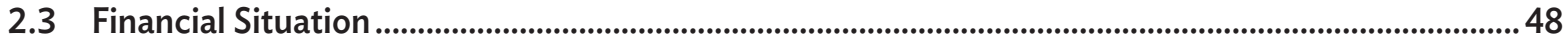

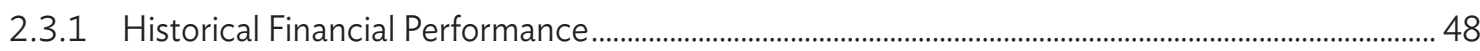

2.3.2 Size of Operation (Average Annual Turnover) (Optional) ........................................................... 48

Contract Type B: Custom-Designed, High-Value, and Technically Complex Items ..................................... 49

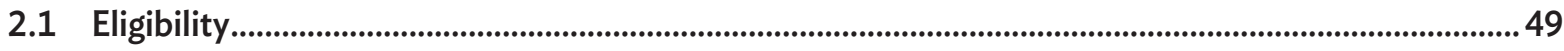

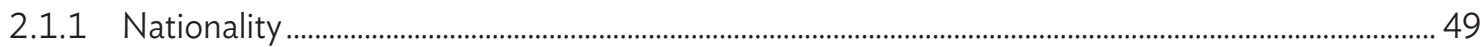

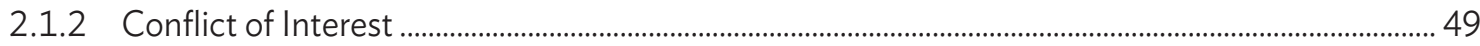

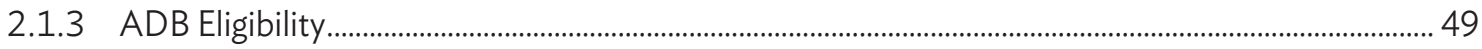

2.1.4 Government-Owned Enterprise .......................................................................................................... 50

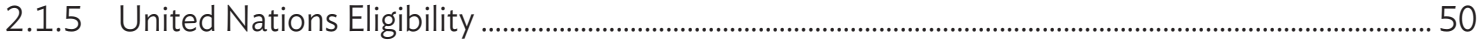

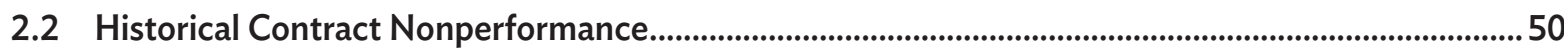

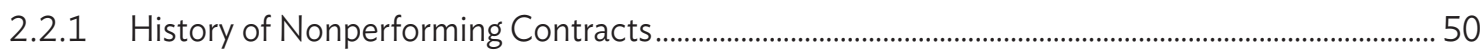

2.2.2 Suspension Based on Execution of Bid-Securing Declaration ............................................................. 51

2.2.3 Pending Litigation .................................................................................................................................................... 51

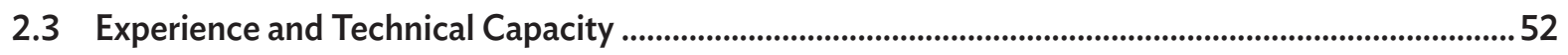

2.3.1 Contractual Experience ......................................................................................................................................... 52

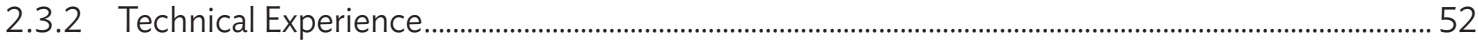

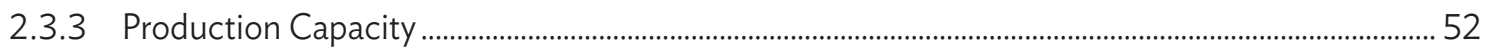

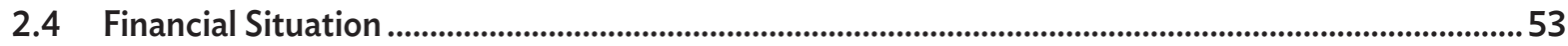

2.4.1 Historical Financial Performance ............................................................................................................ 53

2.4.2 Size of Operation (Average Annual Turnover) ........................................................................................... 54

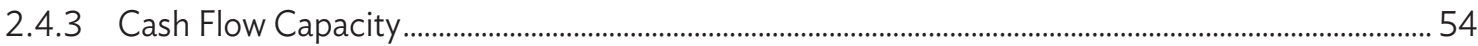




\section{Evaluation Criteria}

\subsection{Technical Criteria}

These criteria should specify the minimum technical level that the Goods and Related Services shall have to comply with Section 6 (Schedule of Supply). Whenever possible, these criteria should be evaluated on a pass-fail system, with a minimum acceptable level for each criteria enumerated.

However, a minor deficiency in technical compliance may not be cause for rejection of the Bid. An example of such nonsubstantive deficiency is the case of an auxiliary motor of which the power rating falls short of that specified, or a proposal to supply cross-ply tires for a vehicle instead of radial-ply as specified. The cost of making good any deficiency should likewise be added to the Bid Price concerned. The most frequently used methods assign to the nonconforming items or components, prices based on similar methods described above under scope, with the price of the nonconforming items or components deducted.

[Insert: "The cost of all quantifiable deviations or deficiencies from the technical requirements as specified in Section 6 (Schedule of Supply) shall be evaluated. The Purchaser will make its own assessment of the cost of these deviations or deficiencies for the purpose of ensuring fair comparison of Bids."]

\subsection{Domestic Preference}

The borrower may, with the agreement of $A D B$, grant domestic preference in the evaluation of bids under OCB procedure to bids offering certain goods manufactured in the country of the borrower, when compared to bids offering such goods manufactured elsewhere. The nationality of the manufacturer or supplier is not a condition for such eligibility. The method described below, as stipulated in the Financing Agreement, shall be followed in the evaluation and comparison of bids. For landlocked countries requiring multimodal transportation CIP (...point of entry) should be used instead of CIF (...port of destination).

\subsubsection{Method of Application}

1. For comparison, responsive bids shall be classified in one of the following three groups:

(a) Group A: Bids exclusively offering goods manufactured in the country of the Borrower if the bidder establishes to the satisfaction of the Borrower and ADB that (i) labor, raw material, and components from within the country of the Borrower will account for $30 \%$ or more of the EXW price of the product offered, and (ii) the production facility in which those goods will be manufactured or assembled has been engaged in manufacturing or assembling such goods at least since the time of bid submission.

(b) Group B: All other bids offering goods manufactured in the country of the Borrower.

(c) Group C: Bids offering goods manufactured abroad that have been already imported or that will be directly imported.

2. The price quoted for goods in bids of groups $A$ and $B$ shall include all duties and taxes paid or payable on the basic materials or components purchased in the domestic market or imported, but shall exclude the sales and similar taxes on the finished product. The price quoted for goods in bids of group C shall be on CIF or CIP (place of destination), which is exclusive of customs duties and other import taxes already paid or to be paid. 
3. In the first step, all evaluated Bids in each group shall be compared to determine the lowest bid in each group. Such lowest evaluated bids shall be compared with each other and if, as a result of this comparison, a bid from group $A$ or group $B$ is the lowest, it shall be selected for the award.

4. If as a result of the comparison under paragraph 3 above, the lowest evaluated Bid is a Bid from group $C$, the lowest evaluated bid from group $C$ shall be further compared with the lowest evaluated Bid from group $A$ after adding to the evaluated price of goods offered in the Bid from group $C$, for the purpose of this further comparison only, an amount equal to [insert a percentage not exceeding 15\%] of the CIF or CIP bid price. The lowest evaluated Bid determined from this last comparison shall be selected.

\subsection{Economic Criteria}

Economic criteria are applied when evaluating a Bid to determine the lowest evaluated Bid. These criteria are the bid price and other factors expressed in monetary terms such as those related to characteristics, performance, and terms and conditions of the purchase of the goods. The monetary values of the factors provide the adjustment of the bid price for comparison purposes. For energy-consuming equipment and facilities, adjustment for efficiency over and above the minimum functional guarantees indicated in the specifications (e.g., generators, pumps), losses (e.g., transformers), and future operating costs of the equipment may be taken into account in determining the evaluated Bid Price. The financial cost for these adjustments (added to or deducted from the Bid Price as the case may be) shall be made only when it is specified in the Bidding Document that these functional guarantees and projected operating costs are factors in bid evaluation. The methods of calculation for these evaluation factors shall be clearly specified in the Bidding Document. Deviations from the specified manner of cost calculation shall not be introduced.

Examples of such criteria appear below.

\subsubsection{Adjustment for Scope}

\subsubsection{Local Handling and Inland Transportation}

If the Purchaser wishes to consider during bid evaluation the costs for inland transportation, insurance, and other services within the Purchaser's country incidental to delivery of the goods to their final destination, then

(a) the Purchaser must define these services in Section 6 (Schedule of Supply), and

(b) Bidders must be required to quote for these services as part of their bid price in the Price Schedule for Related Services to be Offered from Outside and Within the Purchaser's Country provided in Section 4 (Bidding Forms).

In such case, the following provision should be used:

[Insert: "Costs for inland transportation, insurance, and other incidental costs for delivery of the goods from the EXW premises, or port of entry, or border point to Project Site as defined in Section 6 (Schedule of Supply), shall be quoted in the Price Schedule for Related Services to be Offered from Outside and Within the Purchaser's Country provided In Section 4 (Bidding Forms). These costs will be taken into account during bid evaluation. If a Bidder fails to include such costs in its Bid, then these costs will be estimated by the Purchaser on the basis of published tariffs by the rail or road transport agencies, insurance companies, or other appropriate sources, and added to EXW or CIF or CIP price."] 


\subsubsection{Minor Omissions or Missing Items}

The cost of minor omissions or missing items in the scope of supply, services, etc. should be added to the Bid Price to allow for Bid comparison on an equal basis. The price adjustment should be based on a reasonable estimate of the cost by the executing agency, engineer, consultant, or bid evaluation committee, taking into consideration the corresponding quoted prices from other conforming Bids. The price adjustment should be based on the fair price of the omitted item. The most frequently used method is to use the price equal to the highest price quoted for the same item by the other responsive Bidders.

[Insert: "Pursuant to ITB 32.3, the cost of all quantifiable nonmaterial nonconformities or omissions from the contractual and commercial conditions shall be evaluated. The Purchaser will make its own assessment of the cost of any nonmaterial nonconformities and omissions for the purpose of ensuring fair comparison of Bids."]

\subsubsection{Adjustment for Deviations from the Terms of Payment}

The Purchaser must state here whether deviations from the terms of payment as specified in Special Conditions of Contract (SCC) 16.1, are permitted or not. If permitted, the Purchaser shall evaluate deviations from the terms of payment in the following manner. The Purchaser shall first evaluate the Bids based on the terms of payment specified in SCC 16.1. The Purchaser shall then add an adjustment to the Bid Price to take into account the differences in cash flows. The adjustment shall be calculated as the discounted cash flow of the incremental payments of the alternative compared with those of the terms of payment specified by the Purchaser.

[Alternative 1. Insert: "Deviations from the Terms of Payment as specified in SCC 16.1 are not permitted."]

[Alternative 2. Insert: "Bids offering payment terms that differ from those specified in SCC 16.1 will be accepted but the Bids will be adjusted in the evaluation by adding the cost of the interest involved at the rate of (... specify commercial rate applicable).”]

\subsubsection{Adjustment for Deviations in the Delivery and Completion Schedule}

Bidders are required to base their prices on the Delivery and Completion Schedule specified in Section 6 (Schedule of Supply). The Purchaser must state here whether deviations from the specified Delivery and Completion Schedule are permitted or not. If permitted, the Purchaser shall evaluate deliveries by adding the corresponding price adjustment in accordance with the procedure outlined below.

[Alternative 1. Insert: "Deviations from the Delivery and Completion Schedule specified in Section 6 (Schedule of Supply) are not permitted."]

[Alternative 2. Insert: "The Goods covered by this bidding process are required to be delivered in accordance with, and completed within, the Delivery and Completion Schedule specified in Section 6 (Schedule of Supply). No credit will be given for earlier completion. Bids offering late contract performance schedules will be accepted but the Bids shall be adjusted in the evaluation by adding to the Bid Price at the rate of ( . . specify percentage) of the Bid Price for each day of delay. Bids offering delivery schedules beyond (... specify time limit) of the date specified in Section 6 (Schedule of Supply), shall be rejected."] 


\subsubsection{Operation and Maintenance Costs}

The operation and maintenance (O\&M) costs need to be taken into account for bid evaluation purposes when such costs over the life cycle of the Goods represent an important cost in relation to the capital or investment cost of the Goods. Different technologies may involve large variations in the capital cost of the Goods and the associated O\&M costs. Normally, more elaborate technologies and materials used in the manufacturing of the Goods involve higher investment costs and lower O\&M costs. O\&M costs are evaluated at their present value over the life cycle of the Goods and then added to the price of the Goods. Use of unverifiable future O\&M cost and consumption figures as a factor in economic evaluation should be avoided.

Typical O\&M cost factors for calculation are as follows:

(a) Number of years for initial period of operation. It is recommended that the initial period of operation does not exceed the usual period before a major overhaul of the Goods is required, usually between 5 and 10 years. The load or working cycle (hourly, daily, monthly, seasonal) of the Goods shall be as specified by the Purchaser).

(b) Operating costs such as fuel, electricity, spare parts, labor, and/or other inputs required for the operation of the Goods.

(c) Rate, in percentage, to be used to discount to present value, all of the annual future costs calculated under (b) above for the period specified in (a).

[Insert procedures to be used]

\subsubsection{Spare Parts}

Only those spare parts and tools that are specified on an item-wise basis in the List of Goods and Related Services in Section 6 (Schedule of Supply), shall be taken into account in the bid evaluation. Supplierrecommended spare parts for a specified operating requirement shall not be considered in bid evaluation.

[Insert: "The list of items and quantities of (. . specify spare parts, tools, major assemblies, and selected components), likely to be required during the initial period (. . specify period) of operation is indicated in Section 6 (Schedule of Supply). The total cost of these items at the unit prices quoted in each Bid shall be added to the Bid Price."]

\subsubsection{Performance and Productivity of the Goods}

The adjustment factor for the performance or productivity of the Goods shall be calculated based on the difference between the reference value or norm (i.e., the efficiency) as specified in Section 6 (Schedule of Supply), and the corresponding value guaranteed by the Bidder in its Bid. The method of calculation shall be the following:

[Insert detailed description of the methodology] 


\subsection{Multiple Lots (Contracts)}

If Goods and Related Services are grouped in multiple lots, the following provision must be used:

[Insert: "Goods are grouped in lots. The Purchaser will evaluate and compare Bids on the basis of a lot, or a combination of lots, or as a total of lots to arrive at the least cost combination for the Purchaser by taking into account discounts offered by Bidders in case of award of multiple contracts."]

If a Bidder as defined in ITB 4.1 submits successful Bids for multiple lots (lowest evaluated substantially responsive Bids), the evaluation will also include an assessment of the Bidder's capacity to meet the aggregated qualifying requirements relating to [Purchaser to list here the qualifying requirements set for individual contracts/lots, i.e., production capacity, size of operation]. 


\section{Qualification Criteria}

The Purchaser shall use the appropriate requirements based on the sets of criteria for supply of contracts of offthe-shelf items (Contract Type A) and of high-value and technically complex items (Contract Type B).

\section{Contract Type A: Off-the-Shelf Items}

For the procurement of ordinary, readily available, off-the-shelf items, a thorough checking of the qualification of the Bidders may not be necessary, apart from ensuring that the technical specifications are met, and that the equipment or machinery has been sufficiently tested in practical terms. Examples are furniture for a school project, nonspecialized laboratory equipment for either health or education projects, office equipment such as nonspecialized laptop computers and printers, etc.

The following criteria are to be used to establish the critical qualifications of the Bidder:

\subsection{Eligibility}

\begin{tabular}{|c|c|c|c|c|c|}
\hline Criteria & \multicolumn{4}{|c|}{ Compliance Requirements } & Documents \\
\hline \multirow[b]{2}{*}{ Requirement } & \multirow[b]{2}{*}{ Single Entity } & \multicolumn{3}{|c|}{ Joint Venture } & \multirow[b]{2}{*}{$\begin{array}{l}\text { Submission } \\
\text { Requirements }\end{array}$} \\
\hline & & $\begin{array}{l}\text { All Partners } \\
\text { Combined }\end{array}$ & $\begin{array}{l}\text { Each } \\
\text { Partner }\end{array}$ & $\begin{array}{l}\text { One } \\
\text { Partner }\end{array}$ & \\
\hline
\end{tabular}

\subsubsection{Nationality}

\begin{tabular}{|l|c|c|c|c|c|}
\hline $\begin{array}{l}\text { Nationality in } \\
\text { accordance with } \\
\text { ITB 4.2. }\end{array}$ & $\begin{array}{c}\text { Must meet } \\
\text { requirement }\end{array}$ & $\begin{array}{c}\text { Must meet } \\
\text { requirement }\end{array}$ & $\begin{array}{c}\text { Must meet } \\
\text { requirement }\end{array}$ & $\begin{array}{c}\text { Not } \\
\text { applicable }\end{array}$ & $\begin{array}{c}\text { Bid Submission } \\
\text { Sheet; Forms ELI - 1 } \\
\text { and ELI -2 }\end{array}$ \\
\hline
\end{tabular}

\subsubsection{Conflict of Interest}

\begin{tabular}{|l|c|c|c|c|c|}
\hline $\begin{array}{l}\text { No conflicts } \\
\text { of interest in } \\
\text { accordance with } \\
\text { ITB 4.3. }\end{array}$ & $\begin{array}{c}\text { Must meet } \\
\text { requirement }\end{array}$ & $\begin{array}{c}\text { Must meet } \\
\text { requirement }\end{array}$ & $\begin{array}{c}\text { Must meet } \\
\text { requirement }\end{array}$ & $\begin{array}{c}\text { Not } \\
\text { applicable }\end{array}$ & $\begin{array}{c}\text { Bid Submission } \\
\text { Sheet }\end{array}$ \\
\hline
\end{tabular}

\subsubsection{ADB Eligibility}

\begin{tabular}{|l|c|c|c|c|c|}
\hline $\begin{array}{l}\text { Not having } \\
\text { been declared } \\
\text { ineligible by ADB, } \\
\text { as described in } \\
\text { ITB 4.4. }\end{array}$ & $\begin{array}{c}\text { Must meet } \\
\text { requirement }\end{array}$ & $\begin{array}{c}\text { Must meet } \\
\text { requirement }\end{array}$ & $\begin{array}{c}\text { Must meet } \\
\text { requirement }\end{array}$ & $\begin{array}{c}\text { Not } \\
\text { applicable }\end{array}$ & $\begin{array}{c}\text { Bid Submission } \\
\text { Sheet }\end{array}$ \\
\hline
\end{tabular}




\subsubsection{Government-Owned Enterprise}

\begin{tabular}{|l|c|c|c|c|c|}
\hline $\begin{array}{l}\text { Bidder required to } \\
\text { meet conditions of } \\
\text { ITB 4.5. }\end{array}$ & $\begin{array}{c}\text { Must meet } \\
\text { requirement }\end{array}$ & $\begin{array}{c}\text { Must meet } \\
\text { requirement }\end{array}$ & $\begin{array}{c}\text { Must meet } \\
\text { requirement }\end{array}$ & $\begin{array}{c}\text { Not } \\
\text { applicable }\end{array}$ & $\begin{array}{c}\text { Bid Submission } \\
\text { Sheet; Forms ELI - } 1 \\
\text { and } \\
\text { ELI - 2 }\end{array}$ \\
\hline
\end{tabular}

\subsubsection{United Nations Eligibility}

\begin{tabular}{|l|c|c|c|c|c|}
\hline $\begin{array}{l}\text { Not having been } \\
\text { excluded by an act } \\
\text { of compliance with } \\
\text { a United Nations } \\
\text { Security Council } \\
\text { resolution in } \\
\text { accordance with }\end{array}$ & $\begin{array}{c}\text { Must meet } \\
\text { requirement }\end{array}$ & $\begin{array}{c}\text { Must meet } \\
\text { requirement }\end{array}$ & $\begin{array}{c}\text { Must meet } \\
\text { requirement }\end{array}$ & $\begin{array}{c}\text { Not } \\
\text { applicable }\end{array}$ & $\begin{array}{c}\text { Bid Submission } \\
\text { Sheet }\end{array}$ \\
ITB 4.8. & & & & & \\
\hline
\end{tabular}

\section{NOTE}

It is the obligation of the Purchaser to confirm an entity's eligibility by checking ADB's complete Sanctions List (for all bidders) at various stages of bidding process including bid evaluation, prior to contract award, as well as during processing of contract variations, extensions or modifications. ADB has the right to monitor the Purchaser's compliance to this obligation.

ADB's Complete Sanctions List and the guide on how to get its access are available at https://www.adb.org/who-we-are/integrity/sanctions.

\subsection{Experience and Technical Capacity}

\subsubsection{Contractual Experience}

\begin{tabular}{|c|c|c|c|c|c|}
\hline Criteria & \multicolumn{4}{|c|}{ Compliance Requirements } & Documents \\
\hline \multirow[b]{2}{*}{ Requirement } & \multirow[b]{2}{*}{ Single Entity } & \multicolumn{3}{|c|}{ Joint Venture } & \multirow[b]{2}{*}{$\begin{array}{c}\text { Submission } \\
\text { Requirements }\end{array}$} \\
\hline & & $\begin{array}{c}\text { All Partners } \\
\text { Combined }\end{array}$ & $\begin{array}{c}\text { Each } \\
\text { Partner }\end{array}$ & $\begin{array}{c}\text { One } \\
\text { Partner }\end{array}$ & \\
\hline $\begin{array}{l}\text { Successful completion as main } \\
\text { supplier within the last . . . ... } \\
\text { years, of at least . ....... } \\
\text { contracts each valued at . . . . . } \\
\text { with nature, and complexity } \\
\text { similar to the scope of supply } \\
\text { described in Section } 6 \\
\text { (Schedule of Supply). }\end{array}$ & $\begin{array}{l}\text { Must meet } \\
\text { requirement }\end{array}$ & $\begin{array}{l}\text { Must meet } \\
\text { requirement }\end{array}$ & $\begin{array}{c}\text { Not } \\
\text { applicable }\end{array}$ & $\begin{array}{c}\text { Not } \\
\text { applicable }\end{array}$ & Form EXP $-1^{d}$ \\
\hline
\end{tabular}

a Indicate time period usually 3 years.

b Two to five depending on the scope of supply, higher range for off-the-shelf items.

c Usually $80 \%$ of the estimated value of the subject contract.

d In addition to the submission of Form EXP-1, the Bidder shall provide the Signed Contract Agreement. 


\subsection{Financial Situation}

\subsubsection{Historical Financial Performance}

\begin{tabular}{|c|c|c|c|c|c|}
\hline Criteria & \multicolumn{4}{|c|}{ Compliance Requirements } & Documents \\
\hline \multirow[b]{2}{*}{ Requirement } & \multirow[b]{2}{*}{$\begin{array}{l}\text { Single } \\
\text { Entity }\end{array}$} & \multicolumn{3}{|c|}{ Joint Venture } & \multirow[b]{2}{*}{$\begin{array}{l}\text { Submission } \\
\text { Requirements }\end{array}$} \\
\hline & & $\begin{array}{l}\text { All Partners } \\
\text { Combined }\end{array}$ & $\begin{array}{c}\text { Each } \\
\text { Partner }\end{array}$ & $\begin{array}{c}\text { One } \\
\text { Partner }\end{array}$ & \\
\hline $\begin{array}{l}\text { Submission of audited financial } \\
\text { statements or, if not required by the } \\
\text { law of the Bidder's country, other } \\
\text { financial statements acceptable to } \\
\text { the Purchaser, for the last . ...... a } \\
\text { years to demonstrate the current } \\
\text { soundness of the Bidder's financial } \\
\text { position. As a minimum, the } \\
\text { Bidder's net worth for the last } \\
\text { year calculated as the difference } \\
\text { between total assets and total } \\
\text { liabilities should be positive. }\end{array}$ & $\begin{array}{l}\text { Must meet } \\
\text { requirement }\end{array}$ & $\begin{array}{c}\text { Not } \\
\text { applicable }\end{array}$ & $\begin{array}{l}\text { Must meet } \\
\text { requirement }\end{array}$ & $\begin{array}{c}\text { Not } \\
\text { applicable }\end{array}$ & Form FIN - 1 \\
\hline
\end{tabular}

a Indicate time period between 3 and 5 years.

\section{NOTES}

The financial information provided by the Bidder should be reviewed in its entirety to allow a truly informed judgment, and the pass-fail decision on the financial position of the Bidder should be given on this basis. Any abnormal feature that may lead to financial problems should alert the Purchaser to seek expert professional advice for further review and interpretation.

\subsubsection{Size of Operation (Average Annual Turnover) (optional)}

\begin{tabular}{|c|c|c|c|c|c|}
\hline Criteria & \multicolumn{4}{|c|}{ Compliance Requirements } & Documents \\
\hline \multirow[b]{2}{*}{ Requirement } & \multirow[b]{2}{*}{$\begin{array}{l}\text { Single } \\
\text { Entity }\end{array}$} & \multicolumn{3}{|c|}{ Joint Venture } & \multirow[b]{2}{*}{$\begin{array}{l}\text { Submission } \\
\text { Requirements }\end{array}$} \\
\hline & & $\begin{array}{c}\text { All Partners } \\
\text { Combined }\end{array}$ & $\begin{array}{c}\text { Each } \\
\text { Partner }\end{array}$ & $\begin{array}{c}\text { One } \\
\text { Partner }\end{array}$ & \\
\hline $\begin{array}{l}\text { Minimum average annual turnover } \\
\text { of } \$ \ldots . . \ldots{ }^{a} \text { calculated as total } \\
\text { payments received by the Bidder } \\
\text { for contracts completed or under } \\
\text { execution over the last ..... b years. }\end{array}$ & $\begin{array}{l}\text { Must meet } \\
\text { requirement }\end{array}$ & $\begin{array}{l}\text { Must meet } \\
\text { requirement }\end{array}$ & $\begin{array}{l}\text { Must meet } \\
\qquad \ldots \ldots{ }^{c} \\
\text { of the } \\
\text { requirement }\end{array}$ & $\begin{array}{l}\text { Must meet } \\
\qquad \ldots{ }^{d} \\
\text { of the } \\
\text { requirement }\end{array}$ & Form FIN - 2 \\
\hline
\end{tabular}

a The amount stated should normally not be less than two times the annualized value of the subject contract, expressed as $2 \times \mathrm{V} / \mathrm{T}$; where $\mathrm{V}$ is the Purchaser's estimated cost (including contingencies), and $\mathrm{T}$ is the contract duration in years. For contract duration of up to 1 year, T of " 1 " should be used. The multiplier of 2 may be reduced for very large contracts but should not be less than 1.5.

b Insert number of years in words and figures and indicate time period between 3 and 5 years.

c The Purchaser is to define this value based on the minimum amount required that all partners of the Joint Venture must meet, taking joint and several liability into account, usually at least $25 \%$.

d The Purchaser is to define this value based on the minimum amount required that one partner of the Joint Venture must meet, usually at least $40 \%$. 


\section{Contract Type B: Custom-Designed, High-Value, and Technically Complex Items}

If there is a need to ensure that the lowest-evaluated Bidder has the necessary qualifications to successfully fulfill its obligations under the contract, as the case may be for the procurement of high-value and technically complex items of equipment and machinery for which a separate prequalification exercise was not considered feasible, the Purchaser may specify appropriate qualification criteria in this section. Examples are supervisory control and data acquisition (SCADA) equipment for large water or energy projects, generators, transformers, locomotives, etc.

Depending on the nature of the procurement, taking money and time at risk into account, Bidders' qualifications regarding critical aspects of their financial, technical, production, procurement, shipping, installation, and other capabilities necessary to perform the contract may need to be examined. It will be necessary to seek only information essential to determine the Bidder's capabilities to execute the contract satisfactorily. All these criteria shall be evaluated on a pass-fail basis only. Minimum acceptable levels with regard to Bidders' experience in supplying goods and related services with comparable technical parameters, their manufacturing and installation capacity, their financial capability, and other factors must be defined.

Some of the individual Experience and Technical Capacity and Financial Situation criteria below may not be used provided the Purchaser is satisfied that the critical criteria to determine the Bidder's qualifications are stated.

\subsection{Eligibility}

\begin{tabular}{|c|c|c|c|c|c|}
\hline Criteria & \multicolumn{4}{|c|}{ Compliance Requirements } & Documents \\
\hline & & \multicolumn{3}{|c|}{ Joint Venture } & \multirow[b]{2}{*}{$\begin{array}{l}\text { Submission } \\
\text { Requirements }\end{array}$} \\
\hline Requirement & Single Entity & $\begin{array}{c}\text { All Partners } \\
\text { Combined }\end{array}$ & $\begin{array}{l}\text { Each } \\
\text { Partner }\end{array}$ & $\begin{array}{l}\text { One } \\
\text { Partner }\end{array}$ & \\
\hline
\end{tabular}

\subsubsection{Nationality}

\begin{tabular}{|l|c|c|c|c|c|}
\hline $\begin{array}{l}\text { Nationality in } \\
\text { accordance with } \\
\text { ITB 4.2. }\end{array}$ & $\begin{array}{c}\text { Must meet } \\
\text { requirement }\end{array}$ & $\begin{array}{c}\text { Must meet } \\
\text { requirement }\end{array}$ & $\begin{array}{c}\text { Must meet } \\
\text { requirement }\end{array}$ & $\begin{array}{c}\text { Not } \\
\text { applicable }\end{array}$ & $\begin{array}{c}\text { Bid Submission } \\
\text { Sheet; Forms ELI - } 1 \\
\text { and ELI-2 }\end{array}$ \\
\hline
\end{tabular}

\subsubsection{Conflict of Interest}

\begin{tabular}{|l|c|c|c|c|c|}
\hline $\begin{array}{l}\text { No conflicts } \\
\text { of interest in } \\
\text { accordance with } \\
\text { ITB 4.3. }\end{array}$ & $\begin{array}{c}\text { Must meet } \\
\text { requirement }\end{array}$ & $\begin{array}{c}\text { Must meet } \\
\text { requirement }\end{array}$ & $\begin{array}{c}\text { Must meet } \\
\text { requirement }\end{array}$ & $\begin{array}{c}\text { Not } \\
\text { applicable }\end{array}$ & $\begin{array}{c}\text { Bid Submission } \\
\text { Sheet }\end{array}$ \\
\hline
\end{tabular}

\subsubsection{ADB Eligibility}

\begin{tabular}{|l|c|c|c|c|c|}
\hline $\begin{array}{l}\text { Not having } \\
\text { been declared } \\
\text { ineligible by ADB, } \\
\text { as described in } \\
\text { ITB 4.4. }\end{array}$ & $\begin{array}{c}\text { Must meet } \\
\text { requirement }\end{array}$ & $\begin{array}{c}\text { Must meet } \\
\text { requirement }\end{array}$ & $\begin{array}{c}\text { Must meet } \\
\text { requirement }\end{array}$ & $\begin{array}{c}\text { Not } \\
\text { applicable }\end{array}$ & $\begin{array}{c}\text { Bid Submission } \\
\text { Sheet }\end{array}$ \\
\hline
\end{tabular}




\subsubsection{Government-Owned Enterprise}

\begin{tabular}{|l|c|c|c|c|c|}
\hline $\begin{array}{l}\text { Bidder required to } \\
\text { meet conditions of } \\
\text { ITB 4.5. }\end{array}$ & $\begin{array}{c}\text { Must meet } \\
\text { requirement }\end{array}$ & $\begin{array}{c}\text { Must meet } \\
\text { requirement }\end{array}$ & $\begin{array}{c}\text { Must meet } \\
\text { requirement }\end{array}$ & $\begin{array}{c}\text { Not } \\
\text { applicable }\end{array}$ & $\begin{array}{c}\text { Bid Submission } \\
\text { Sheet; Forms ELI - } 1 \\
\text { and } \\
\text { ELI - 2 }\end{array}$ \\
\hline
\end{tabular}

\subsubsection{United Nations Eligibility}

\begin{tabular}{|c|c|c|c|c|c|}
\hline $\begin{array}{l}\text { Not having been } \\
\text { excluded by an act } \\
\text { of compliance with } \\
\text { a United Nations } \\
\text { Security Council } \\
\text { resolution in } \\
\text { accordance with } \\
\text { ITB } 4.8 \text {. }\end{array}$ & $\begin{array}{l}\text { Must meet } \\
\text { requirement }\end{array}$ & $\begin{array}{l}\text { Must meet } \\
\text { requirement }\end{array}$ & $\begin{array}{l}\text { Must meet } \\
\text { requirement }\end{array}$ & $\begin{array}{c}\text { Not } \\
\text { applicable }\end{array}$ & $\begin{array}{c}\text { Bid Submission } \\
\text { Sheet }\end{array}$ \\
\hline
\end{tabular}

\section{NOTES}

It is the obligation of the Purchaser to confirm an entity's eligibility by checking ADB's complete Sanctions List (for all bidders) at various stages of bidding process including bid evaluation, prior to contract award, as well as during processing of contract variations, extensions or modifications. ADB has the right to monitor the Purchaser's compliance to this obligation.

ADB's Complete Sanctions List and the guide on how to get its access are available at https://www.adb.org/who-we-are/ integrity/sanctions.

\subsection{Historical Contract Nonperformance}

\subsubsection{History of Nonperforming Contracts}

\begin{tabular}{|c|c|c|c|c|c|}
\hline Criteria & \multicolumn{4}{|c|}{ Compliance Requirements } & Documents \\
\hline \multirow[b]{2}{*}{ Requirement } & \multirow[b]{2}{*}{ Single Entity } & \multicolumn{3}{|c|}{ Joint Venture } & \multirow[b]{2}{*}{$\begin{array}{c}\text { Submission } \\
\text { Requirements }\end{array}$} \\
\hline & & $\begin{array}{c}\text { All Partners } \\
\text { Combined }\end{array}$ & $\begin{array}{c}\text { Each } \\
\text { Partner }\end{array}$ & $\begin{array}{c}\text { One } \\
\text { Partner }\end{array}$ & \\
\hline $\begin{array}{l}\text { Nonperformance of a contract } \\
\text { did not occur as a result of } \\
\text { contractor default since } \\
1 \text { January [insert year]. }\end{array}$ & $\begin{array}{l}\text { Must meet } \\
\text { requirement }\end{array}$ & $\begin{array}{l}\text { Must meet } \\
\text { requirement }\end{array}$ & $\begin{array}{l}\text { Must meet } \\
\text { requirement }^{b}\end{array}$ & Not applicable & Form CON - 1 \\
\hline
\end{tabular}

a Nonperformance, as decided by the Purchaser, shall include all contracts where (a) nonperformance was not challenged by the contractor, including through referral to the dispute resolution mechanism under the respective contract, and (b) contracts that were so challenged but fully settled against the contractor. Nonperformance shall not include contracts where Purchasers decision was overruled by the dispute resolution mechanism. Nonperformance must be based on all information on fully settled disputes or litigation, i.e. dispute or litigation that has been resolved in accordance with the dispute resolution mechanism under the respective contract and where all appeal instances available to the Bidder have been exhausted.

b This requirement also applies to contracts executed by the Bidder as Joint Venture partner. 


\subsubsection{Suspension Based on Execution of Bid-Securing Declaration}

\begin{tabular}{|c|c|c|c|c|c|}
\hline Criteria & \multicolumn{4}{|c|}{ Compliance Requirements } & Documents \\
\hline \multirow[b]{2}{*}{ Requirement } & \multirow[b]{2}{*}{ Single Entity } & \multicolumn{3}{|c|}{ Joint Venture } & \multirow[b]{2}{*}{$\begin{array}{c}\text { Submission } \\
\text { Requirements }\end{array}$} \\
\hline & & $\begin{array}{c}\text { All Partners } \\
\text { Combined }\end{array}$ & $\begin{array}{c}\text { Each } \\
\text { Partner }\end{array}$ & $\begin{array}{c}\text { One } \\
\text { Partner }\end{array}$ & \\
\hline $\begin{array}{l}\text { Not under suspension based } \\
\text { on execution of a Bid-Securing } \\
\text { Declaration pursuant to ITB } 4.6 \text {. }\end{array}$ & $\begin{array}{l}\text { Must meet } \\
\text { requirement }\end{array}$ & $\begin{array}{l}\text { Must meet } \\
\text { requirement }\end{array}$ & $\begin{array}{l}\text { Must meet } \\
\text { requirement }\end{array}$ & $\begin{array}{c}\text { Not } \\
\text { applicable }\end{array}$ & $\begin{array}{c}\text { Bid Submission } \\
\text { Sheet }\end{array}$ \\
\hline
\end{tabular}

\subsubsection{Pending Litigation}

Pending litigation and arbitration criterion [shall/shall not] apply. ${ }^{a}$

\begin{tabular}{|c|c|c|c|c|c|}
\hline Criteria & \multicolumn{4}{|c|}{ Compliance Requirements } & Documents \\
\hline \multirow[b]{2}{*}{ Requirement } & \multirow[b]{2}{*}{ Single Entity } & \multicolumn{3}{|c|}{ Joint Venture } & \multirow[b]{2}{*}{$\begin{array}{c}\text { Submission } \\
\text { Requirements }\end{array}$} \\
\hline & & $\begin{array}{c}\text { All Partners } \\
\text { Combined }\end{array}$ & $\begin{array}{c}\text { Each } \\
\text { Partner }\end{array}$ & $\begin{array}{c}\text { One } \\
\text { Partner }\end{array}$ & \\
\hline $\begin{array}{l}\text { All pending litigation, arbitration } \\
\text { or other material events } \\
\text { impacting the net worth and/ } \\
\text { or liquidity of the bidder, if any, } \\
\text { shall be treated as resolved } \\
\text { against the Bidder and so shall in } \\
\text { total not represent more than . } \\
\ldots . . .{ }^{\text {b }} \text { percent of the Bidder's } \\
\text { net worth calculated as the } \\
\text { difference between total assets } \\
\text { and total liabilities. }\end{array}$ & $\begin{array}{l}\text { Must meet } \\
\text { requirement }\end{array}$ & $\begin{array}{c}\text { Not } \\
\text { applicable }\end{array}$ & $\begin{array}{l}\text { Must meet } \\
\text { requirement }\end{array}$ & $\begin{array}{c}\text { Not } \\
\text { applicable }\end{array}$ & Form CON - 1 \\
\hline
\end{tabular}

a The Purchaser may choose whether to apply or not to apply this criterion:

1) If the Purchaser chooses to apply this criterion, it should indicate "shall apply" and use the table in 2.2.3, or

2) If the Purchaser chooses not to apply this criterion, it should indicate "shall not apply" and delete the table in 2.2.3.

b If the criterion is applied, the Purchaser should indicate a percentage within the range of $50 \%-100 \%$ of the Bidder's net worth. 


\subsection{Experience and Technical Capacity}

\subsubsection{Contractual Experience}

\begin{tabular}{|c|c|c|c|c|c|}
\hline Criteria & \multicolumn{4}{|c|}{ Compliance Requirements } & Documents \\
\hline \multirow[b]{2}{*}{ Requirement } & \multirow[b]{2}{*}{ Single Entity } & \multicolumn{3}{|c|}{ Joint Venture } & \multirow[b]{2}{*}{$\begin{array}{l}\text { Submission } \\
\text { Requirements }\end{array}$} \\
\hline & & $\begin{array}{l}\text { All Partners } \\
\text { Combined }\end{array}$ & $\begin{array}{c}\text { Each } \\
\text { Partner }\end{array}$ & $\begin{array}{c}\text { One } \\
\text { Partner }\end{array}$ & \\
\hline $\begin{array}{l}\text { Successful completion as main } \\
\text { supplier within the last ....... } \\
\text { years, of at least ........ } \\
\text { contracts each valued at ...... } \\
\text { with nature, and complexity } \\
\text { similar to the scope of supply } \\
\text { described in Section } 6 \\
\text { (Schedule of Supply). }\end{array}$ & $\begin{array}{l}\text { Must meet } \\
\text { requirement }\end{array}$ & $\begin{array}{l}\text { Must meet } \\
\text { requirement }\end{array}$ & $\begin{array}{c}\text { Not } \\
\text { applicable }\end{array}$ & $\begin{array}{c}\text { Not } \\
\text { applicable }\end{array}$ & Form EXP $-1^{d}$ \\
\hline
\end{tabular}

a Indicate time period usually 3 years.

b Two to five depending on the scope of supply, the lower range for high-value and technically complex contracts.

c Usually $80 \%$ of the estimated value of the subject contract.

d In addition to the submission of Form EXP-1, the Bidder shall provide the Signed Contract Agreement.

\subsubsection{Technical Experience}

\begin{tabular}{|c|c|c|c|c|c|}
\hline Criteria & \multicolumn{4}{|c|}{ Compliance Requirements } & Documents \\
\hline \multirow[b]{2}{*}{ Requirement } & \multirow[b]{2}{*}{ Single Entity } & \multicolumn{3}{|c|}{ Joint Venture } & \multirow[b]{2}{*}{$\begin{array}{l}\text { Submission } \\
\text { Requirements }\end{array}$} \\
\hline & & $\begin{array}{l}\text { All Partners } \\
\text { Combined }\end{array}$ & $\begin{array}{c}\text { Each } \\
\text { Partner }\end{array}$ & $\begin{array}{c}\text { One } \\
\text { Partner }\end{array}$ & \\
\hline $\begin{array}{l}\text { The Bidder shall demonstrate that } \\
\text { the goods offered have } \\
\text { (i) been in production for } \\
\text { at least ..... }{ }^{\text {years, and }} \\
\text { (ii) been sold a minimum of ... b } \\
\text { units of similar type and } \\
\text { specification over the last } \\
\text { three ( } 3 \text { ) years; } \\
\text { (iii) been in operation for a } \\
\text { minimum of ....... }{ }^{c} \text { years. }\end{array}$ & $\begin{array}{l}\text { Must meet } \\
\text { requirement }\end{array}$ & $\begin{array}{l}\text { Must meet } \\
\text { requirement }\end{array}$ & $\begin{array}{c}\text { Not } \\
\text { applicable }\end{array}$ & $\begin{array}{c}\text { Not } \\
\text { applicable }\end{array}$ & Form EXP $-2^{d}$ \\
\hline
\end{tabular}

a Purchaser to indicate the number of years in production.

b Purchaser to indicate the number of units sold of similar capacity.

c Purchaser to indicate the number of years in operation.

d In addition to the submission of Form EXP-2, the Bidder shall provide the Signed Contract Agreement. 


\subsubsection{Production Capacity}

\begin{tabular}{|c|c|c|c|c|c|}
\hline Criteria & \multicolumn{4}{|c|}{ Compliance Requirements } & Documents \\
\hline \multirow[b]{2}{*}{ Requirement } & \multirow[b]{2}{*}{ Single Entity } & \multicolumn{3}{|c|}{ Joint Venture } & \multirow[b]{2}{*}{$\begin{array}{l}\text { Submission } \\
\text { Requirements }\end{array}$} \\
\hline & & $\begin{array}{c}\text { All Partners } \\
\text { Combined }\end{array}$ & $\begin{array}{c}\text { Each } \\
\text { Partner }\end{array}$ & $\begin{array}{c}\text { One } \\
\text { Partner }\end{array}$ & \\
\hline $\begin{array}{l}\text { The Bidder or manufacturer shall } \\
\text { demonstrate }{ }^{a} \text { that it can supply } \\
\text { the type, size, and quantity of the } \\
\text { goods as required by Purchaser in } \\
\text { accordance with the Delivery and } \\
\text { Completion Schedule in Section } 6 \\
\text { (Schedule of Supply). }\end{array}$ & $\begin{array}{l}\text { Must meet } \\
\text { requirement }\end{array}$ & $\begin{array}{l}\text { Must meet } \\
\text { requirement }\end{array}$ & $\begin{array}{c}\text { Not } \\
\text { applicable }\end{array}$ & $\begin{array}{c}\text { Not } \\
\text { applicable }\end{array}$ & Form EXP - 3 \\
\hline
\end{tabular}

a Bidder or Manufacturer shall provide evidence of production output.

\subsection{Financial Situation}

\subsubsection{Historical Financial Performance}

\begin{tabular}{|c|c|c|c|c|c|}
\hline Criteria & \multicolumn{4}{|c|}{ Compliance Requirements } & Documents \\
\hline \multirow[b]{2}{*}{ Requirement } & \multirow[b]{2}{*}{ Single Entity } & \multicolumn{3}{|c|}{ Joint Venture } & \multirow[b]{2}{*}{$\begin{array}{l}\text { Submission } \\
\text { Requirements }\end{array}$} \\
\hline & & $\begin{array}{l}\text { All Partners } \\
\text { Combined }\end{array}$ & $\begin{array}{c}\text { Each } \\
\text { Partner }\end{array}$ & $\begin{array}{c}\text { One } \\
\text { Partner }\end{array}$ & \\
\hline $\begin{array}{l}\text { Submission of audited financial } \\
\text { statements or, if not required by the } \\
\text { law of the Bidder's country, other } \\
\text { financial statements acceptable to } \\
\text { the Purchaser, for the last . . . . . } \\
\text { years to demonstrate the current } \\
\text { soundness of the Bidder's financial } \\
\text { position. As a minimum, the } \\
\text { Bidder's net worth for the last } \\
\text { year calculated as the difference } \\
\text { between total assets and total } \\
\text { liabilities should be positive. }\end{array}$ & $\begin{array}{l}\text { Must meet } \\
\text { requirement }\end{array}$ & $\begin{array}{c}\text { Not } \\
\text { applicable }\end{array}$ & $\begin{array}{l}\text { Must meet } \\
\text { requirement }\end{array}$ & $\begin{array}{c}\text { Not } \\
\text { applicable }\end{array}$ & Form FIN - 1 \\
\hline
\end{tabular}

a Indicate time period between 3 and 5 years.

\section{NOTES}

The financial information provided by the bidder should be reviewed in its entirety to allow a truly informed judgment, and the pass-fail decision on the financial position of the bidder should be given on this basis. Any abnormal feature that may lead to financial problems should alert the Purchaser to seek expert professional advice for further review and interpretation. 


\subsubsection{Size of Operation (Average Annual Turnover)}

\begin{tabular}{|c|c|c|c|c|c|}
\hline Criteria & \multicolumn{4}{|c|}{ Compliance Requirements } & Documents \\
\hline \multirow[b]{2}{*}{ Requirement } & \multirow[b]{2}{*}{$\begin{array}{l}\text { Single } \\
\text { Entity }\end{array}$} & \multicolumn{3}{|c|}{ Joint Venture } & \multirow[b]{2}{*}{$\begin{array}{c}\text { Submission } \\
\text { Requirements }\end{array}$} \\
\hline & & $\begin{array}{l}\text { All Partners } \\
\text { Combined }\end{array}$ & $\begin{array}{c}\text { Each } \\
\text { Partner }\end{array}$ & $\begin{array}{c}\text { One } \\
\text { Partner }\end{array}$ & \\
\hline 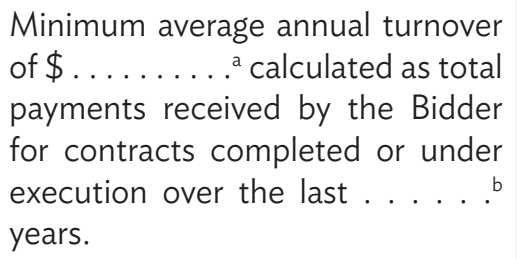 & $\begin{array}{l}\text { Must meet } \\
\text { requirement }\end{array}$ & $\begin{array}{l}\text { Must meet } \\
\text { requirement }\end{array}$ & $\begin{array}{c}\text { Must meet } \\
\ldots \ldots{ }^{c} \\
\text { of the } \\
\text { requirement }\end{array}$ & $\begin{array}{l}\text { Must meet } \\
\ldots \ldots . . . \\
\text { of the } \\
\text { requirement }\end{array}$ & Form FIN - 2 \\
\hline
\end{tabular}

a The amount stated should normally not be less than two times the annualized value of the subject contract, expressed as $2 \times \mathrm{V} / \mathrm{T}$; where $\mathrm{V}$ is the purchaser's estimated cost (including contingencies), and $\mathrm{T}$ is the contract duration in years. For contract duration of up to 1 year, T of " 1 " should be used. The multiplier of 2 may be reduced for very large contracts but should not be less than 1.5.

b Insert number of years in words and figures and indicate time period between 3 and 5 years.

c The Purchaser is to define this value based on the minimum amount required that all partners of the Joint Venture must meet, taking joint and several liability into account, usually at least $25 \%$.

d The Purchaser is to define this value based on the minimum amount required that one partner of the Joint Venture must meet, usually at least $40 \%$.

\subsubsection{Cash Flow Capacity}

If the bid evaluation process and the decision for the award of the Contract takes more than 1 year from the date of bid submission, Bidders may be asked to resubmit their latest information on financial resources supported by latest audited accounts/audited financial statements, or if not required by the law of the Bidder's country, other financial statements acceptable to the Purchaser, and the Bidders' financial capacity will be reassessed on this basis.

\begin{tabular}{|c|c|c|c|c|c|}
\hline Criteria & \multicolumn{4}{|c|}{ Compliance Requirements } & Documents \\
\hline \multirow[b]{2}{*}{ Requirement } & \multirow[b]{2}{*}{$\begin{array}{l}\text { Single } \\
\text { Entity }\end{array}$} & \multicolumn{3}{|c|}{ Joint Venture } & \multirow[b]{2}{*}{$\begin{array}{l}\text { Submission } \\
\text { Requirements }\end{array}$} \\
\hline & & $\begin{array}{c}\text { All Partners } \\
\text { Combined }\end{array}$ & $\begin{array}{c}\text { Each } \\
\text { Partner }\end{array}$ & $\begin{array}{c}\text { One } \\
\text { Partner }\end{array}$ & \\
\hline $\begin{array}{l}\text { Availability of or access to liquid } \\
\text { assets, }{ }^{a} \text { lines of credit, and other } \\
\text { finances sufficient to meet cash } \\
\text { flow requirement which is } \$ \ldots \ldots \\
\ldots . . .\end{array}$ & $\begin{array}{l}\text { Must meet } \\
\text { requirement }\end{array}$ & $\begin{array}{l}\text { Must meet } \\
\text { requirement }\end{array}$ & $\begin{array}{l}\text { Must meet } \\
\ldots \ldots{ }^{c} \\
\text { of the } \\
\text { requirement }\end{array}$ & $\begin{array}{l}\text { Must meet } \\
\qquad \ldots d^{d} \\
\text { of the } \\
\text { requirement }\end{array}$ & Form FIN - 3 \\
\hline
\end{tabular}

a Liquid assets mean cash and cash equivalents, short-term financial instruments, short-term available-for-sale-securities, marketable securities, trade receivables, short-term financing receivables, and other assets that can be converted into cash within 1 year.

b The Purchaser is to specify the cash flow requirement for the subject contract based on the estimated value of the initial delivery of the goods in accordance with the Delivery and Completion Schedule in Section 6 (Schedule of Supply).

c The Purchaser is to define this value based on the minimum amount required that all partners of the Joint Venture must meet, taking joint and several liability into account, usually at least $25 \%$.

d The Purchaser is to define this value based on the minimum amount required that one partner of the Joint Venture must meet, usually at least $40 \%$. 


\section{Bidder is not a Manufacturer under Contract Type B}

If a Bidder is not a manufacturer, but is offering the Goods on behalf of the Manufacturer under Manufacturer's Authorization Form (Section 4, Bidding Forms), the Bidder shall demonstrate that it meets the requirements for

- 2.1 Eligibility,

- 2.2 Historical Contract Nonperformance,

- 2.3.1 Contractual Experience,

- 2.4.1 Historical Financial Performance,

- 2.4.2 Size of Operation (Average Annual Turnover), and

- 2.4.3 Cash Flow Capacity.

The Manufacturer shall separately demonstrate that it meets the requirements for

- 2.1 Eligibility,

- 2.3.2 Technical Experience, and

- 2.3.3 Production Capacity.

If the procurement is for Goods that are well known internationally and are supplied by various dealers, such as vehicles and similar types of equipment, it may not be necessary to examine the technical experience and production capacity of the Manufacturer. 


\section{Section 4: Bidding Forms}

The Purchaser shall include in this Section all bidding forms that the Bidder must complete and include in its Bid.

\section{Table of Forms}

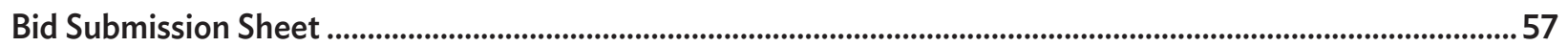

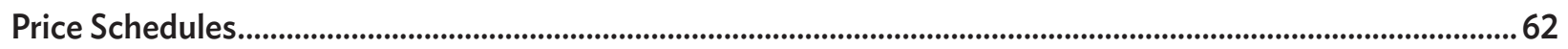

Price Schedule for Goods to Be Offered from Within the Purchaser's Country .................................................... 63

Price Schedule for Goods to Be Offered from Outside the Purchaser's Country..................................................... 64

Price Schedule for Related Services to Be Offered from Outside and Within the Purchaser's Country........... 65

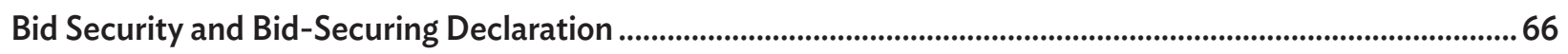

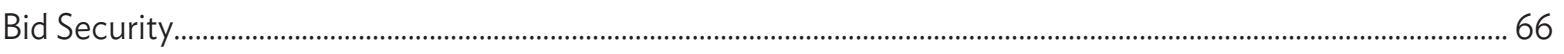

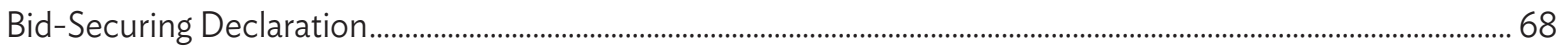

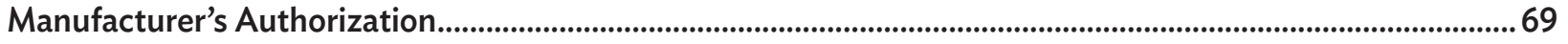

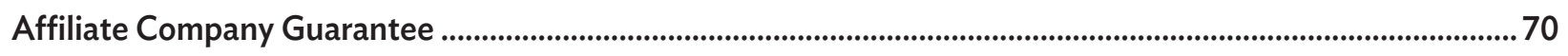

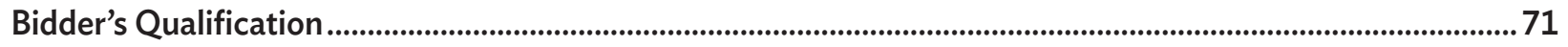

Form ELI - 1: Bidder's Information Sheet ………………………………………………………………………….. 72

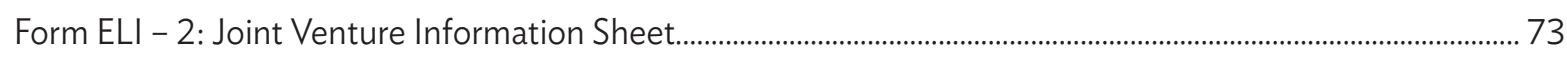

Form CON - 1: Historical Contract Nonperformance ...................................................................................................... 74

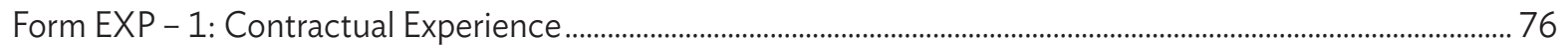

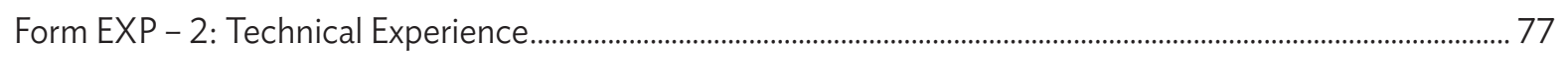

Form EXP - 3: Production Capacity .......................................................................................................................................... 78

Form FIN - 1: Historical Financial Performance................................................................................................................. 79

Form FIN - 2: Size of Operation (Average Annual Turnover) ..................................................................................... 80

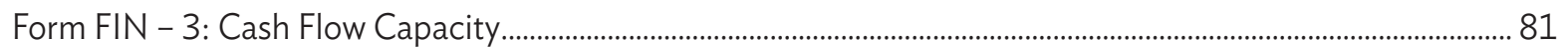




\section{Bid Submission Sheet}

\section{NOTES}

1. The Bidder must accomplish the Bid Submission Sheet on its letterhead clearly showing the Bidder's complete name and address.

2. To be used for Single-Stage: One-Envelope Bidding Procedure.

Date:

Open Competitive Bidding (OCB) No.:

Invitation for Bid (IFB) No.:

Alternative No:

[Insert identification no. if this is an alternative bid; if alternative bid is not permitted, delete this field]

To: [insert complete name of the Purchaser]

We, the undersigned, declare that:

(a) We have examined and have no reservations to the Bidding Documents, including Addenda issued in accordance with Instructions to Bidders (ITB) 8.

(b) We acknowledge that we have read and understand ADB's Anticorruption Policy (1998) and Integrity Principles and Guidelines (2015), both as amended from time to time.

(c) We offer to supply in conformity with the Bidding Documents and in accordance with the delivery schedule specified in Section 6 (Schedule of Supply), the following Goods and Related Services: [insert a brief description of the goods and related services].

(d) The total price of our Bid, excluding any discounts offered in item (d) below, is

[amount of foreign currency in words], [amount in figures], and [amount of local currency in words], [amount in figures]

The total bid price from the price schedules should be entered by the bidder inside this box. Absence of the total bid price in the Bid Submission Sheet may result in the rejection of the bid.

(e) The discounts offered and the methodology for their application are as follows:

Discounts: If our Bid is accepted, the following discounts shall apply [specify in detail each discount offered and the specific item of the Schedule of Supply to which it applies]

Methodology of Application of the Discounts: The discounts shall be applied using the following method: [specify in detail the method that shall be used to apply the discounts]

(f) Our Bid shall be valid for a period of [insert validity period as specified in ITB 20.1 of the Bid Data Sheet (BDS)] days starts from the date fixed for the bid submission deadline in accordance with ITB 24.1, and it shall remain binding upon us and may be accepted at any time before the expiration of that period. 
(g) If our Bid is accepted, we commit to obtain a Performance Security in accordance with the Bidding Documents.

(h) Our firm, including any Subcontractors or Suppliers for any part of the Contract, have nationalities from eligible countries in accordance with ITB 4.2.

(i) We, our directors, key officers, key personnel, including any Subcontractors, consultants, subconsultants, manufacturers, service providers or Suppliers for any part of the contract, do not have any conflict of interest in accordance with ITB 4.3.

If there is any conflict of interest, please state details:

(i) Parties involved in the conflict of interest:

(ii) Details about the conflict of interest:

(j) We are not participating, as a Bidder, either individually or as partner in a Joint Venture, in more than one Bid in this bidding process in accordance with ITB 4.3(e), other than alternative offers in accordance with the Bidding Documents.

(k) Our firm, Joint Venture partners, our respective direct and indirect shareholders, directors, key officers, key personnel, associates, parent company, affiliates or subsidiaries, including any Subcontractors, consultants, subconsultants, manufacturers, service providers or Suppliers for any part of the contract, are not subject to, or not controlled by any entity or individual that is subject to a temporary suspension or a debarment imposed by the Asian Development Bank; or a debarment imposed by the Asian Development Bank in accordance with the Agreement for Mutual Enforcement of Debarment Decisions between the Asian Development Bank and other development bank. ${ }^{1}$

(I) Our firm, Joint Venture partners, our respective direct and indirect shareholders, directors, key officers, key personnel, associates, parent company, affiliates or subsidiaries, including any Subcontractors, consultants, subconsultants, manufacturers, service providers or Suppliers for any part of the contract, are not under ongoing investigation and/or sanctions proceedings by the Asian Development Bank or any multilateral development bank.

If under ongoing investigation and/or sanction proceedings by the Asian Development Bank or any multilateral development bank, please state details:

(i) Name of the multilateral development bank:

(ii) Reason for the ongoing investigation / allegations:

(m) Our firm, Joint Venture partners, our respective direct and indirect shareholders, directors, key officers, key personnel, associates, parent company, affiliates or subsidiaries, including any Subcontractors, consultants, subconsultants, manufacturers, service providers or Suppliers for any part of the Contract, are not temporarily suspended, debarred, declared ineligible, or subject to any national and/or international sanctions by any country, any international organization, any multilateral development bank and other donor agency.

1 These institutions include African Development Bank, European Bank for Reconstruction and Development (EBRD), Inter-American Development Bank (IADB), and the World Bank Group. According to paragraph 9 of the Agreement, other international financial institutions may join upon the consent of all Participating Institutions and signature of a Letter of Adherence by the international financial institution substantially in the form provided (Annex B to the Agreement). Upon adherence, such international financial institution shall become a Participating Institution for purposes of the Agreement. Bidders are advised to check www.adb.org/integrity for updates. 
If so temporarily suspended, debarred, declared ineligible, or subject to any national and/or international sanctions by any country, any international organization, any multilateral development bank and other donor agency, please state details (as applicable to each Joint Venture partner, their respective direct or indirect shareholders, directors, key officers, key personnel, associate, parent company, affiliate, subsidiaries, Subcontractors, consultants, subconsultants, manufacturers, service providers and/or Suppliers):

(i) Name of Institution:

(ii) Period of the temporary suspension, debarment, ineligibility, or national or international sanction [start and end date]:

(iii) Reason for the temporary suspension, debarment, ineligibility, or national or international sanction:

(n) Our firm, Joint Venture partners, associates, parent company, affiliates or subsidiaries, including any Subcontractors, consultants, subconsultants, manufacturers, service providers, Suppliers, key officers, directors, and key personnel have never been charged or convicted with any criminal offense (including felonies but excluding misdemeanors) or infractions and/or violations of ordinance; nor charged or found liable in any civil or administrative proceedings in the last 10 years; or undergoing investigation for such, or subject to any criminal, civil or administrative orders, monitorship or enforcement actions.

If so charged, convicted/found liable, under ongoing investigation, or subject to orders, monitorship or enforcement actions, please state details:

(i) Nature of the offense, violation, proceedings, investigation, and/or monitorship or enforcement actions:

(ii) Court, area of jurisdiction and/or the enforcement agency:

(iii) Resolution [i.e. dismissed; settled; or convicted/duration of penalty]:

(iv) Other relevant details [please specify]:

(o) Our firm, Joint Venture partners, our respective direct and indirect shareholders, directors, key officers, key personnel, associates, affiliates or subsidiaries, including any Subcontractors, consultants, subconsultants, manufacturers, service providers or Suppliers, can make and receive electronic fund transfer payments through the international banking system or otherwise discharge the Purchaser's obligation upon initiation of wire transfer.

If unable to make or receive funds through the international banking system or otherwise discharge the Purchaser's obligation upon initiation of wire transfer, please state the details:

(i) Nature of the restriction:

(ii) Jurisdiction of the restriction:

(iii) Other relevant details:

(p) Our firm, Joint Venture partners, associates, parent company, affiliates or subsidiaries, including any Subcontractors, consultants, subconsultants, manufacturers, service providers or Suppliers, key officers, directors and key personnel are not from a country which is prohibited to export goods or services to, or receive any payments from the Purchaser's country and/or are not prohibited to receive payments for particular goods or services by the Purchaser's country by an act of compliance with a decision of the United Nations Security Council taken under Chapter VII of the Charter of the United Nations. 
(q) We understand that it is our obligation to notify the Purchaser of any changes in connection with the matters described in paragraphs (i), (k), (I), (m), (n), (o), (p) and (t) of this Bid Submission Sheet.

(r) [We are not a government-owned enterprise] / [We are a government-owned enterprise but meet the requirements of ITB 4.5]. ${ }^{2}$

(s) We have not been suspended nor declared ineligible by the Purchaser based on execution of a Bid-Securing Declaration in accordance with ITB 4.6.

(t) We have paid, or intend to pay, either directly or indirectly, the following commissions, gratuities, or fees with respect to the bidding process or execution of the Contract: ${ }^{3}$

Name of Recipient

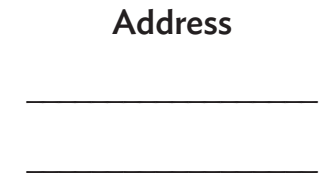

Reason

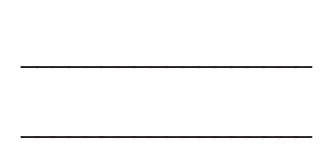

Amount

(u) We understand that this Bid, together with your written acceptance thereof included in your notification of award, shall constitute a binding contract between us, until a formal Contract is prepared and executed.

(v) We understand that you are not bound to accept the lowest evaluated Bid or any other Bid that you may receive.

(w) At any time following submission of our Bid,, we shall permit, and shall cause our Joint Venture partners, directors, key officers, key personnel, associates, parent company, affiliates or subsidiaries, including any Subcontractors, consultants, subconsultants, manufacturers, service providers or Suppliers for any part of the contract to permit ADB or its representative to inspect our site, assets, accounts and records and other documents relating to the bid submission and to have them audited by auditors appointed by ADB. We understand that failure of this obligation may constitute obstructive practice that may result in debarment and/or contract termination.

(x) Regardless of whether the contract will be awarded to us, we shall preserve all accounts, records and other documents related to bid submission for at least 3 years from the date of submission of the bid or the period prescribed in applicable law, whichever is longer.

(y) If we are awarded the contract, we shall preserve all accounts, records and other documents related to the procurement and execution of the contract for at least 5 years after completing the works contemplated in the relevant contracts or the period prescribed in applicable law, whichever is longer.

Use one of the two options as appropriate.

If none has been paid or is to be paid, indicate "None." 
(z) We certify on behalf of the Bidder, that the information provided in the bid has been fully reviewed, given in good faith, and to the best of our knowledge is true and complete. We understand that it is our obligation to inform the Purchaser of any changes to the information as and when it becomes known to us. We understand that any misrepresentation that knowingly or recklessly misleads, or attempts to mislead may lead to the automatic rejection of the Bid or cancellation of the contract, if awarded, and may result in remedial actions, in accordance with ADB's Anticorruption Policy (1998, as amended to date) and Integrity Principles and Guidelines (2015, as amended from time to time).

Name: [insert complete name of person signing the bid]

In the capacity of [insert legal capacity of person signing the bid]

Signed: [insert signature of person whose name and capacity are shown above]

Duly authorized to sign the Bid for and on behalf of [insert complete name of the bidder]

Date: [insert date of signing] 


\section{Price Schedules}

The Bidder shall complete and submit with its Bid the Price Schedules pursuant to ITB 12 and in accordance with Part 2 Supply Requirements, Section 6 (Schedule of Supply). The list of items in column 1 of the Price Schedules shall coincide with the List of Goods and Related Services specified by the Purchaser in the Schedule of Supply. This Guide helps the Purchaser and Bidder fill out all the required information in the Price Schedule Form.

The units and rates in figures entered into the Price Schedules should be typewritten or if written by hand, must be in print form. Price Schedules not presented accordingly may be considered nonresponsive. Any necessary alterations due to errors, etc., shall be signed by the Bidder. 


\section{Price Schedule for Goods to Be Offered from Within the Purchaser's Country}

Name of Bidder IFB Number Page of

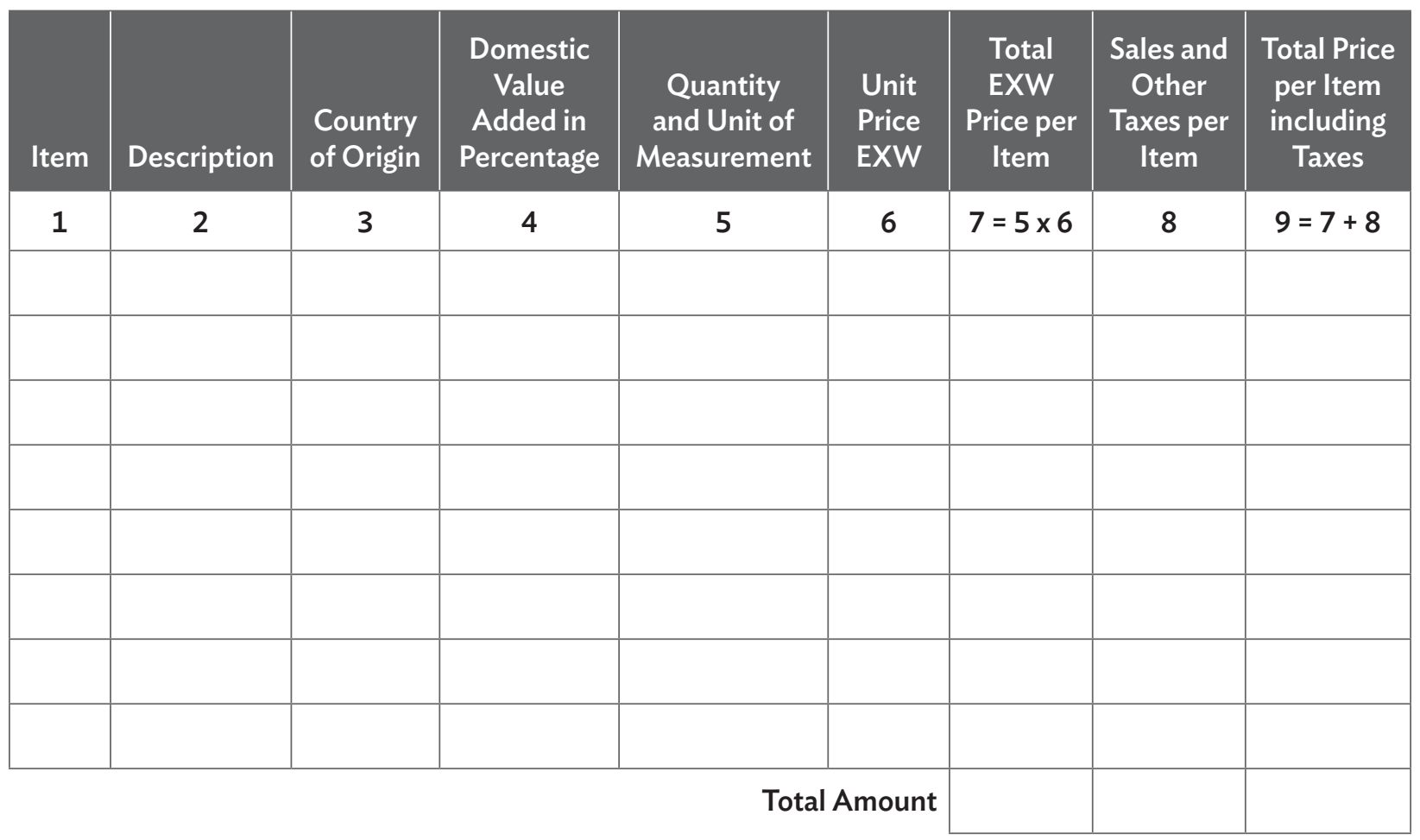

Notes:

Column 4: In accordance with margin of preference ITB 35, if applicable.

Domestic Value Added comprises domestic labor, the domestic content of materials, domestic overheads, and profits from the stage of mining the raw material until final assembly.

Column 6: Incoterm in accordance with ITB 14.

Currency in accordance with ITB 15.

Price shall include all customs duties and sales and other taxes already paid or payable on the components and raw materials used in the manufacture or assembly of the item or the customs duties and sales and other taxes already paid on previously imported items.

Column 8: Payable in the Purchaser's country if Contract is awarded.

Name: [insert complete name of person signing the bid]

In the capacity of [insert legal capacity of person signing the bid]

Signed: [insert signature of person whose name and capacity are shown above]

Duly authorized to sign the Bid for and on behalf of [insert complete name of the Bidder]

Date: [insert date of signing] 


\section{Price Schedule for Goods to Be Offered from Outside the Purchaser's Country}

Name of Bidder

IFB Number

Page of
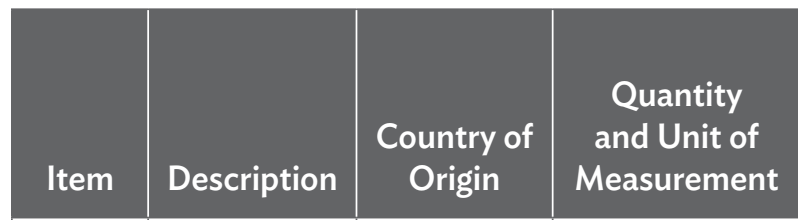

Unit Price

CIF (...)

or

it Price

FOB (...)

CIP (...)

or

Total Price

CIF or CIP

Total Price

FCA (...)

per Item

FOB or FCA per Item

\begin{tabular}{|l|l|l|l|l|l|l|l|}
\hline 1 & 2 & 3 & 4 & 5 & 6 & $7=4 \times 5$ & $8=4 \times 6$ \\
\hline & & & & & & & \\
\hline & & & & & & & \\
\hline & & & & & & & \\
\hline \\
\hline
\end{tabular}

Notes:

Columns 5 and 6: Incoterm in accordance with ITB 14.

Currency in accordance with ITB 15.

Column 6: $\quad$ Only to be used if the Purchaser wishes to reserve transportation and insurance to domestic companies or other designated sources. Identification of the lowest evaluated bid must be on the basis of the $\mathrm{CIF}$ or $\mathrm{CIP}$ price, but the Purchaser may sign the contract on FOB or FCA terms and make its own arrangement for transportation and/or insurance.

Name: [insert complete name of person signing the bid]

In the capacity of [insert legal capacity of person signing the bid]

Signed: [insert signature of person whose name and capacity are shown above]

Duly authorized to sign the Bid for and on behalf of [insert complete name of the Bidder]

Date: [insert date of signing] 


\section{Price Schedule for Related Services to Be Offered from Outside and Within the Purchaser's Country}

Name of Bidder IFB Number Page of

\begin{tabular}{|c|c|c|c|c|c|c|c|}
\hline \multirow[b]{3}{*}{$\begin{array}{l}\text { Item } \\
\text { No. }\end{array}$} & \multirow[b]{3}{*}{ Description } & \multirow[b]{3}{*}{$\begin{array}{l}\text { Country } \\
\text { of Origin }\end{array}$} & \multirow{3}{*}{$\begin{array}{c}\text { Quantity } \\
\text { and Unit of } \\
\text { Measurement }\end{array}$} & \multicolumn{2}{|c|}{ Unit Price } & \multicolumn{2}{|c|}{ Total Price per Item } \\
\hline & & & & (a) & (b) & (a) & (b) \\
\hline & & & & $\begin{array}{l}\text { Foreign } \\
\text { Currency }\end{array}$ & $\begin{array}{l}\text { Local } \\
\text { Currency }\end{array}$ & $\begin{array}{l}\text { Foreign } \\
\text { Currency }\end{array}$ & $\begin{array}{l}\text { Local } \\
\text { Currency }\end{array}$ \\
\hline 1 & 2 & 3 & 4 & $5(a)$ & $5(b)$ & $6(a)=4 \times 5(a)$ & $6(b)=4 \times 5(b)$ \\
\hline & & & & & & & \\
\hline & & & & & & & \\
\hline & & & & & & & \\
\hline & & & & & & & \\
\hline & & & & & & & \\
\hline & & & & & & & \\
\hline & & & & & & & \\
\hline & & & & & al Amount & & \\
\hline
\end{tabular}

Notes:

Columns 5 and 6: Currencies in accordance with ITB 15.

Prices are to be quoted inclusive of all customs duties, sales, and other similar taxes applicable in the Purchaser's country and payable on the Related Services, if the Contract is awarded to the Bidder.

Name: [insert complete name of person signing the bid]

In the capacity of [insert legal capacity of person signing the bid]

Signed: [insert signature of person whose name and capacity are shown above]

Duly authorized to sign the Bid for and on behalf of [insert complete name of the Bidder]

Date: [insert date of signing] 


\section{Bid Security and Bid-Securing Declaration}

When requested in the Bid Data Sheet, the Bidder shall furnish as part of its bid, either a Bid-Securing Declaration or a Bid Security.

In case of an unconditional guarantee issued by a bank, the Bidder shall use the Bid Security Form included in this section or another form acceptable to the Purchaser prior to bid submission pursuant to ITB 21.3. In either case, the form must include the complete name of the Bidder. The bid security shall be valid for 28 days beyond the original validity period of the Bid, or beyond any period of extension if requested under ITB 20.2.

If a Bid-Securing Declaration is specified pursuant to ITB 21.1 the Bidder shall use the form included in this section. 


\section{Bid Security}

\section{Bank Guarantee}

[insert bank's name, and address of issuing branch or office $]^{1}$

Beneficiary: [insert name and address of the Purchaser]

Date: [insert date]

Bid Security No.: [insert number]

We have been informed that [insert name of the Bidder] (hereinafter called "the Bidder") has submitted to you its bid dated [insert date] (hereinafter called "the Bid") for the execution of [insert name of Contract] under Invitation for Bids No. [insert IFB number] ("the IFB").

Furthermore, we understand that, according to your conditions, bids must be supported by a bid guarantee.

At the request of the Bidder, we [insert name of bank] hereby irrevocably undertake to pay you any sum or sums not exceeding in total an amount of [insert amount in words] [insert amount in figures] upon receipt by us of your first demand in writing accompanied by a written statement, stating that the Bidder is in breach of its obligation(s) under the bid conditions, because the Bidder

(a) has withdrawn its Bid during the period of bid validity specified by the Bidder in the Bid Submission Sheet; or

(b) does not accept the correction of errors in accordance with the Instructions to Bidders (hereinafter "the ITB"); or

(c) having been notified of the acceptance of its Bid by the Purchaser during the period of bid validity, (i) fails or refuses to execute the Contract Agreement; or (ii) fails or refuses to furnish the Performance Security, in accordance with the ITB.

This guarantee will expire (a) if the Bidder is the successful Bidder, upon our receipt of copies of the Contract Agreement signed by the Bidder and the Performance Security issued to you upon the instruction of the Bidder; or (b) if the Bidder is not the successful Bidder, upon the earlier of (i) our receipt of a copy of your notification to the Bidder of the name of the successful Bidder, or (ii) 28 days after the expiration of the Bidder's bid.

Consequently, any demand for payment under this guarantee must be received by us at the office indicated above on or before that date.

This guarantee is subject to the Uniform Rules for Demand Guarantees (URDG) 2010 Revisions, ICC Publication No. $758 .^{2}$

\footnotetext{
[Authorized signature(s) and bank's seal (where appropriate)]
}

All italicized text is for use in preparing this form and shall be deleted from the final document.

Or the purchaser may use "Uniform Rules for Demand Guarantees (URDG), ICC Publication No. 458” as appropriate. 


\section{Bid-Securing Declaration}

Date: [insert date (as day, month, and year)]

Bid No.: [insert number of bidding process]

Alternative No.: [insert identification no. if this is a bid for an alternative]

To: [insert complete name of the Purchaser]

We, the undersigned, declare that:

We understand that, according to your conditions, bids must be supported by a Bid-Securing Declaration.

We accept that we will automatically be suspended from being eligible for bidding in any contract with the Borrower for the period of time of [insert number of years indicated in ITB 21.2 of the BDS] starting on the date that we receive a notification from the Purchaser that our Bid-Securing Declaration is executed, if we are in breach of our obligation(s) under the bid conditions, because we

(a) have withdrawn our Bid during the period of bid validity specified in the Bid Submission Sheet; or

(b) do not accept the correction of errors in accordance with the Instructions to Bidders (hereinafter "the ITB"); or

(c) having been notified of the acceptance of our Bid by the Purchaser during the period of bid validity, (i) fail or refuse to execute the Contract Agreement, if required, or (ii) fail or refuse to furnish the Performance Security, in accordance with the ITB.

We understand this Bid-Securing Declaration shall expire if we are not the successful Bidder, upon the earlier of (i) our receipt of your notification to us of the name of the successful Bidder; or (ii) 28 days after the expiration of our Bid.

Signed: [insert signature of person whose name and capacity are shown]

In the capacity of [insert legal capacity of person signing the Bid-Securing Declaration]

Name: [insert complete name of person signing the Bid-Securing Declaration]

Duly authorized to sign the bid for and on behalf of [insert complete name of the bidder]

Dated on day of [insert date of signing]

Corporate Seal [where appropriate] 


\section{Manufacturer's Authorization}

$\begin{array}{ll}\text { Date: } & \text { [insert date (as day, month, and year) of bid submission }] \\ \text { OCB No.: } & \quad \text { [insert number of bidding process }]\end{array}$

To: [insert complete name of the Purchaser]

\section{WHEREAS}

We [insert complete name of the Manufacturer], who are official manufacturers of [insert type of goods manufactured], having factories at [insert full address of Manufacturer's factories], do hereby authorize [insert complete name of the Bidder] to submit a bid the purpose of which is to provide the following goods, manufactured by us [insert name and/or brief description of the goods], and to subsequently negotiate and sign the Contract.

We hereby extend our full guarantee and warranty in accordance with Clause 28 of the General Conditions, with respect to the goods offered by the above firm.

Signed: [insert signature(s) of authorized representative(s) of the Manufacturer]

Name: [insert complete name(s) of authorized representative(s) of the Manufacturer]

Title: [insert title]

Duly authorized to sign this Authorization on behalf of [insert complete name of the Manufacturer]

Dated on__ day of ___ _ _ _ _ _ _ _ _ _ _ _ _ signing]

\section{NOTES}

All italicized text is for use in preparing this form and shall be deleted from the final document.

The Bidder shall require the Manufacturer to fill out this form in accordance with the instructions indicated.

This letter of authorization should be signed by a person with the proper authority to sign documents that are binding on the Manufacturer. The Bidder shall include it in its bid, if so indicated in the BDS. 


\section{Affiliate Company Guarantee}

Name of Contract/Contract No.:

Name and address of Purchaser:

[together with successors and assigns].

We have been informed that [name of Contractor] (hereinafter called the "Contractor") is submitting an offer for the above-referenced Contract in response to your invitation, and that the conditions of your invitation require its offer to be supported by an affiliate company guarantee.

In consideration of you, the Purchaser, awarding the Contract to the Contractor, we [name of affiliated company] irrevocably and unconditionally guarantee to you, as a primary obligation, that (i) throughout the duration of the Contract, we will make available to the Contractor our financial, technical capacity, expertise and resources required for the Contractor's satisfactory performance of the Contract; and (ii) we are fully committed, along with the Contractor, to ensuring a satisfactory performance of the Contract.

If the Contractor fails to so perform its obligations and liabilities and comply with the Contract, we will indemnify the Purchaser against and from all damages, losses and expenses (including legal fees and expenses) which arise from any such failure for which the Contractor is liable to the Purchaser under the Contract.

This guarantee shall come into full force and effect when the Contract comes into full force and effect. If the Contract does not come into full force and effect within a year of the date of this guarantee, or if you demonstrate that you do not intend to enter into the Contract with the Contractor, this guarantee shall be void and ineffective. This guarantee shall continue in full force and effect until all the Contractor's obligations and liabilities under the Contract have been discharged, when this guarantee shall expire and shall be returned to us, and our liability hereunder shall be discharged absolutely.

This guarantee shall apply and be supplemental to the Contract as amended or varied by the Purchaser and the Contractor from time to time. We hereby authorize them to agree on any such amendment or variation, the due performance of which and compliance with which by the Contractor are likewise guaranteed hereunder. Our obligations and liabilities under this guarantee shall not be discharged by any allowance of time or other indulgence whatsoever by the Purchaser to the Contractor, or by any variation or suspension of the works to be executed under the Contract, or by any amendments to the Contract or to the constitution of the Contractor or the Purchaser, or by any other matters, whether with or without our knowledge or consent.

This guarantee shall be governed by the law of the same country (or other jurisdiction) that governs the Contract and any dispute under this guarantee shall be finally settled under the [Rules or Arbitration provided in the Contract]. We confirm that the benefit of this guarantee may be assigned subject only to the provisions for assignment of the Contract.

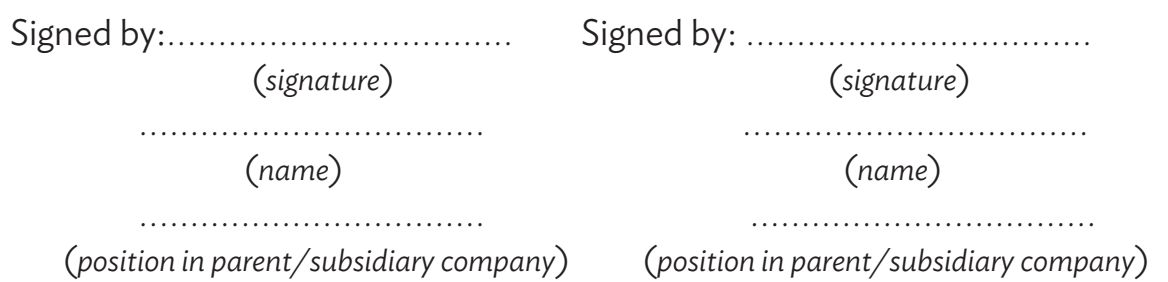

Date:

\section{NOTE}

If permitted in accordance with ITB 38.2 of the BDS, the Bidder shall provide the Affiliate Company Guarantee Form filled out and signed by each subsidiary, parent entity, or affiliate that the Bidder submits for consideration of the Purchaser in determining its qualifications. 


\section{Bidder's Qualification}

To establish its qualifications to perform the contract in accordance with Section 3 (Evaluation and Qualification Criteria), the Bidder shall provide the following information requested in the corresponding Information Sheets. 
Form ELI - 1: Bidder's Information Sheet

\section{Bidder's Information}

\begin{tabular}{|c|c|c|c|}
\hline & & Information of the Bidder & $\begin{array}{l}\text { If the Bidder is a subsidiary } \\
\text { or branch, information of any } \\
\text { parent company/companies }\end{array}$ \\
\hline \multirow[t]{2}{*}{ Names } & Full legal name(s) & & \\
\hline & Full trading name(s) (if any) & & \\
\hline \multirow[t]{3}{*}{ Addresses } & Registered address(es) & & \\
\hline & Trading address(es) & & \\
\hline & $\begin{array}{l}\text { Postal address(es) (if different } \\
\text { from trading address) }\end{array}$ & & \\
\hline \multicolumn{2}{|c|}{ Type of organization } & & \\
\hline \multicolumn{2}{|c|}{$\begin{array}{l}\text { Country of constitution/incorporation/ } \\
\text { registration }\end{array}$} & & \\
\hline \multicolumn{2}{|c|}{$\begin{array}{l}\text { Year of constitution/incorporation/ } \\
\text { registration }\end{array}$} & & \\
\hline \multicolumn{2}{|c|}{ Corporate or registration number } & & \\
\hline \multicolumn{2}{|c|}{$\begin{array}{l}\text { In case of a Joint Venture, legal name of } \\
\text { each partner }\end{array}$} & & \\
\hline \multicolumn{2}{|c|}{$\begin{array}{l}\text { Bidder's authorized representative } \\
\text { (name, address, telephone number(s), } \\
\text { fax number(s), and e-mail address) }\end{array}$} & & \\
\hline \multicolumn{4}{|c|}{$\begin{array}{l}\text { Attached are copies of the following documents: } \\
\text { 1. In case of a single entity, articles of incorporation or constitution and company incorporation/registration of } \\
\text { the legal entity named above, in accordance with ITB } 4.1 \text { and ITB } 4.2 \text {. } \\
\text { 2. Authorization to represent the firm or Joint Venture named above, in accordance with ITB } 22.2 \text {. } \\
\text { 3. In case of a Joint Venture, a letter of intent to form a Joint Venture or Joint Venture agreement, in } \\
\text { accordance with ITB 4.1. } \\
\text { 4. In case of a government-owned enterprise, any additional documents not covered under } 1 \text { above required to } \\
\text { comply with ITB 4.5. }\end{array}$} \\
\hline
\end{tabular}


Form ELI - 2: Joint Venture Information Sheet

Each partner of the Joint Venture must fill out this form separately.

\begin{tabular}{|c|c|c|c|}
\hline \multicolumn{4}{|c|}{ Joint Venture Information } \\
\hline \multicolumn{4}{|c|}{ Bidder's legal name } \\
\hline & & \multirow[t]{2}{*}{ Information of the Bidder } & $\begin{array}{l}\text { If any Joint venture partner } \\
\text { is a subsidiary or branch, } \\
\text { information of any parent } \\
\text { company/companies }\end{array}$ \\
\hline \multirow[t]{2}{*}{ Names } & Full legal name(s) & & \\
\hline & Full trading name(s) (if any) & & \\
\hline \multirow[t]{3}{*}{ Addresses } & Registered address(es) & & \\
\hline & Trading address(es) & & \\
\hline & $\begin{array}{l}\text { Postal address(es) (if different } \\
\text { from trading address) }\end{array}$ & & \\
\hline \multicolumn{2}{|c|}{ Type of organization } & & \\
\hline \multicolumn{2}{|c|}{$\begin{array}{l}\text { Country of constitution/incorporation/ } \\
\text { registration }\end{array}$} & & \\
\hline \multicolumn{2}{|c|}{$\begin{array}{l}\text { Year of constitution/incorporation/ } \\
\text { registration }\end{array}$} & & \\
\hline \multicolumn{2}{|c|}{ Corporate or registration number } & & \\
\hline \multicolumn{2}{|c|}{$\begin{array}{l}\text { Joint Venture Partner's authorized } \\
\text { representative information (name, address, } \\
\text { telephone number(s), fax number(s), and } \\
\text { e-mail address) }\end{array}$} & & \\
\hline \multicolumn{4}{|c|}{$\begin{array}{l}\text { Attached are copies of the following documents: } \\
\text { 1. Articles of incorporation or constitution and company incorporation/registration of the legal entity named } \\
\text { above, in accordance with ITB } 4.1 \text { and ITB 4.2. } \\
\text { 2. Authorization to represent the firm named above, in accordance with ITB } 22.2 \text {. } \\
\text { 3. In the case of a government-owned enterprise, documents establishing legal and financial autonomy and } \\
\text { compliance with commercial law, in accordance with ITB 4.5. }\end{array}$} \\
\hline
\end{tabular}




\section{Form CON - 1: Historical Contract Nonperformance}

For Contract type B, each Bidder must fill out this form in accordance with Criteria 2.2.1 and 2.2.3 of Section 3 (Evaluation and Qualification Criteria) to describe any history of nonperforming contracts and pending litigation or arbitration formally commenced against it.

In case of a Joint Venture, each Joint Venture Partner must fill out this form separately and provide the Joint Venture Partner's name:

Joint Venture Partner:

\section{Table 1: History of Nonperforming Contracts}

\section{Choose one of the following:}

$\square$ No nonperforming contracts.

$\square$ Below is a description of nonperforming contracts involving the Bidder (or each Joint Venture partner if Bidder is a Joint Venture).

\begin{tabular}{|c|c|c|c|}
\hline Year & Description & $\begin{array}{c}\text { Amount of } \\
\text { Nonperformed Portion } \\
\text { of Contract } \\
\text { (\$ equivalent) }\end{array}$ & $\begin{array}{c}\text { Total Contract Amount } \\
\text { (\$ equivalent) }\end{array}$ \\
\hline $\begin{array}{l}{[\text { insert }} \\
\text { year }]\end{array}$ & $\begin{array}{l}\text { Contract Identification: [indicate complete } \\
\text { contract name/number, and any other } \\
\text { identification] } \\
\text { Name of Purchaser: [insert full name] } \\
\text { Address of Purchaser: [insert street/city/ } \\
\text { country] } \\
\text { Reason(s) for nonperformance: [indicate } \\
\text { main reason(s)] }\end{array}$ & [insert amount] & [insert amount] \\
\hline
\end{tabular}


Table 2: Pending Litigation and Arbitration

\section{Choose one of the following:}

$\square$ No pending litigation, arbitration or any other material events impacting the net worth and/or liquidity of the bidder.

$\square$ Below is a description of all pending litigation, arbitration against the Bidder or any other material events impacting the net worth and/or liquidity of the bidder (or each Joint Venture partner if Bidder is a Joint Venture).

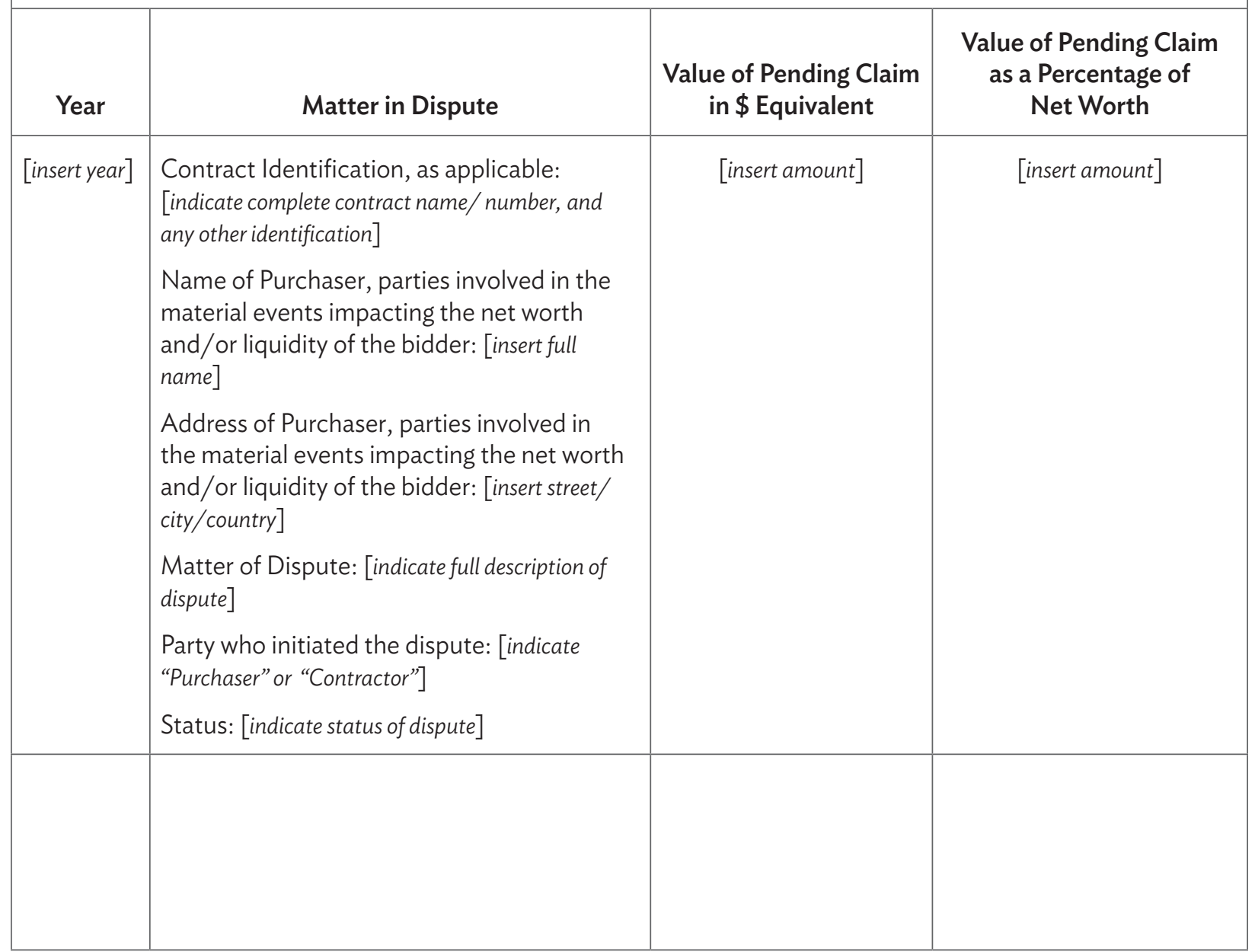

Note: Table 2 of this form shall only be included if Criterion 2.2.3 (Contract Type B) of Section 3 (Evaluation and Qualification Criteria) is applicable. 


\section{Form EXP - 1: Contractual Experience}

Fill out one (1) form per contract. Each contract shall be supported by documents such as Signed Contract Agreement.

\begin{tabular}{|c|c|c|c|}
\hline \multicolumn{4}{|c|}{ Contractual Experience } \\
\hline Contract No...... of ...... & \multicolumn{3}{|c|}{ Contract Identification } \\
\hline \multicolumn{2}{|l|}{ Award Date } & \multicolumn{2}{|c|}{ Completion Date } \\
\hline Role in Contract & $\square \quad$ Manufacturer & $\square$ Supplier & $\square$ Subcontractor \\
\hline Total Contract Amount & \multicolumn{3}{|l|}{$\$$} \\
\hline $\begin{array}{l}\text { If partner in a Joint Venture or } \\
\text { subcontractor, specify participation of } \\
\text { total contract amount }\end{array}$ & Percent of Total & \multicolumn{2}{|l|}{ Amount } \\
\hline \multicolumn{4}{|l|}{$\begin{array}{l}\text { Purchaser's name } \\
\text { Address } \\
\text { Telephone/Fax number } \\
\text { E-mail }\end{array}$} \\
\hline \multicolumn{4}{|c|}{$\begin{array}{l}\text { Description of the Similarity in Accordance with Criterion 2.2.1 (Contract Type A) or 2.3.1 } \\
\text { (Contract Type B) of Section } 3 \text { (Evaluation and Qualification Criteria) }\end{array}$} \\
\hline \multicolumn{4}{|l|}{ NOTE } \\
\hline $\begin{array}{l}\text { The Purchaser should insert } \\
\text { here contractual experience } \\
\text { as described in Criterion 2.2.1 } \\
\text { (Contract Type A) or 2.3.1 } \\
\text { (Contract Type B) of Section } 3 \\
\text { against which the Bidder } \\
\text { demonstrates similarity in the } \\
\text { box on the right-hand side. }\end{array}$ & & & \\
\hline
\end{tabular}

Note: This form shall only be included if either Criterion 2.2.1 (Contract Type A) or 2.3.1(Contract Type B) of Section 3 (Evaluation and Qualification Criteria) is applicable. 


\section{Form EXP - 2: Technical Experience}

Fill out one (1) form per contract. Each contract shall be supported by documents such as Signed Contract Agreement.

\section{Technical Experience}

\section{Name of Product:}

Manufacturer:

Address and Nationality:

\section{Requirements in Accordance with Criterion 2.3.2 (Contract Type B) of Section 3 (Evaluation and Qualification Criteria)}

(i) Product has been in production for at least ...... [a Indicate production history requested. $]$ $\ldots{ }^{\mathrm{a}}$ years.

(ii) Product (or equipment) has been sold a minimum [ ${ }^{\mathrm{b}}$ Indicate number sold and clients.] of ..... b units of similar type and specification over the last three (3) years.

(iii) Product has been in operation for a minimum of . ....... ${ }^{c}$ years.
[ ${ }^{c}$ For equipment/product sold to clients mentioned above, indicate here number of years equipment/product has been in operation.]

Note: This form shall only be included if Criterion 2.3.2 (Contract Type B) of Section 3 (Evaluation and Qualification Criteria) is applicable. Add pages as necessary. Purchaser reserves the right to verify authenticity of Bidder submissions. 


\section{Form EXP - 3: Production Capacity}

Fill out one (1) form per product and manufacturer.

\section{Production Capacity}

\section{Name of Product:}

Manufacturer:

Address and Nationality:

\section{Requirements in Accordance with Criterion 2.3.3 (Contract Type B) of Section 3} (Evaluation and Qualification Criteria)

Production facility 1 (include location):

[Insert the production/supply capacity per month/year as required.]

Production facility 2 (include location):

[Insert the production/supply capacity per month/year as required. $]$

Production facility 3 (include location):

[Insert the production/supply capacity per month/year as required.]

Note: This form shall only be included if Criterion 2.3.3 (Contract Type B) of Section 3 (Evaluation and Qualification Criteria) is applicable. Purchaser reserves the right to verify authenticity of bidder submissions. 


\section{Form FIN - 1: Historical Financial Performance}

Each Bidder must fill out this form.

In case of a Joint Venture, each Joint Venture Partner must fill out this form separately and provide the Joint Venture Partner's name:

Joint Venture Partner:

Financial Data for Previous 3 Years $^{\mathrm{a}}$ [\$ Equivalent]

\begin{tabular}{|c|c|c|c|}
\hline & Year 1: & Year 2: & Year 3: \\
\hline \multicolumn{4}{|c|}{ Information from Balance Sheet } \\
\hline \multicolumn{4}{|l|}{ Total Assets (TA) } \\
\hline \multicolumn{4}{|l|}{ Total Liabilities (TL) } \\
\hline \multicolumn{4}{|l|}{ Net Worth = TA - TL } \\
\hline \multicolumn{4}{|l|}{ Current Assets (CA) } \\
\hline \multicolumn{4}{|l|}{ Current Liabilities (CL) } \\
\hline \multicolumn{4}{|l|}{ Working Capital = CA - CL } \\
\hline Most Recent Working Capital & & \multicolumn{2}{|c|}{$\begin{array}{l}\text { To be obtained for most recent year and carried } \\
\text { forward to FIN - } 3 \text { Line } 1 \text {; in case of joint } \\
\text { ventures, to the corresponding Joint Venture } \\
\text { Partner's FIN - } 3 \text {. }\end{array}$} \\
\hline \multicolumn{4}{|c|}{ Information from Income Statement } \\
\hline \multicolumn{4}{|l|}{ Total Revenues } \\
\hline \multicolumn{4}{|l|}{ Profits Before Taxes } \\
\hline \multicolumn{4}{|l|}{ Profits After Taxes } \\
\hline \multicolumn{4}{|c|}{ 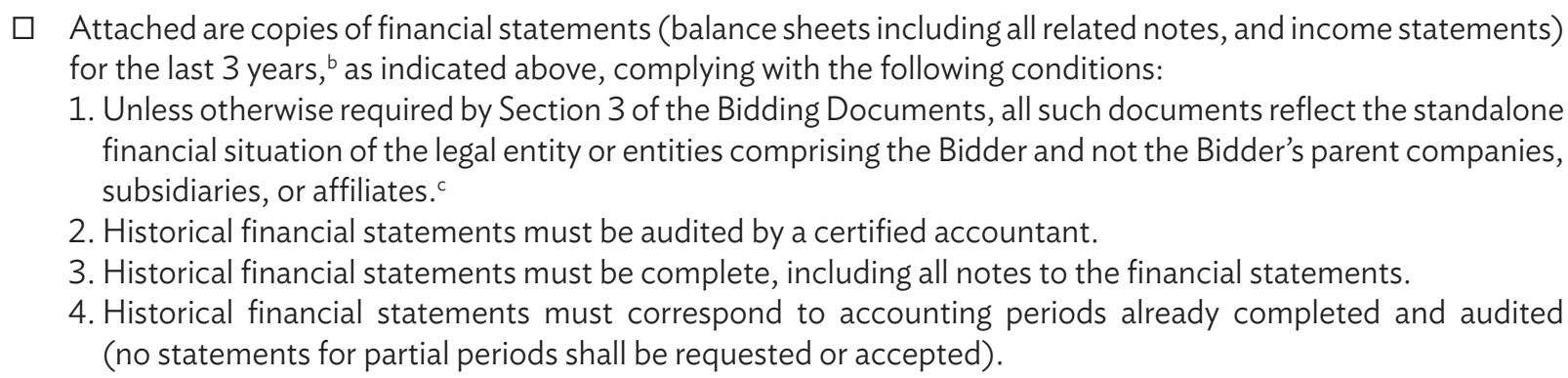 } \\
\hline
\end{tabular}

Note: This form shall only be included if Criterion 2.3.1 (Contract Type A) or 2.4.1 (Contract Type B) of Section 3 (Evaluation and Qualification Criteria) is applicable.

a If the time period indicated under Criterion 2.3.1 (Contract Type A) or 2.4.1 (Contract Type B) of Section 3 (Evaluation and Qualification Criteria) is either 4 or 5 years, then the table columns above should be expanded accordingly.

b The time period stated here should be the same as the time period indicated under Criterion 2.3.1 (Contract Type A) or 2.4.1 (Contract Type B) of Section 3 (Evaluation and Qualification Criteria).

c When financial qualifications of Bidder's parent companies, subsidiaries, or affiliates are permitted in accordance with ITB 38.2 of Section 2, replace the text of condition 1 with "As required by Section 3 of the Bidding Documents, all such documents reflect the standalone financial situation of the legal entity or entities comprising the Bidder, as well as standalone financial situation of such Bidder's parent companies, subsidiaries, or affiliates which are proposed by the Bidder for Criteria 2.4 Financial Situation in Section 3 for consideration of the Purchaser in determining its qualifications." 


\section{Form FIN - 2: Size of Operation (Average Annual Turnover)}

Each Bidder must fill out this form.

The information supplied should be the Annual Turnover of the Bidder or each partner of a Joint Venture for the total certified payments received from the clients for contracts in progress or completed, converted to US dollars at the rate of exchange at the end of the period reported.

In case of a Joint Venture, each Joint Venture Partner must fill out this form separately and provide the Joint Venture Partner's name:

Joint Venture Partner:

\begin{tabular}{|c|c|c|c|}
\hline \multicolumn{4}{|c|}{ Annual Turnover Data for the Last ... Years ${ }^{\mathrm{a}}$} \\
\hline Year & $\begin{array}{c}\text { Amount } \\
\text { Currency }\end{array}$ & $\begin{array}{c}\text { Exchange } \\
\text { Rate }\end{array}$ & \$ Equivalent \\
\hline & & & \\
\hline & & & \\
& & & \\
\hline
\end{tabular}

Note: This form shall only be included if Criterion 2.3.2 (Contract Type A) or 2.4.2 (Contract Type B) of Section 3 (Evaluation and Qualification Criteria) is applicable.

a The Purchaser should insert the period described in Criterion 2.3.2 (Contract Type A) or 2.4.2 (Contract Type B) of Section 3 (Evaluation and Qualification Criteria).

b To determine the average annual turnover, the Purchaser shall divide the sum of each year's annual turnover by the number of years, for which such information was requested. 


\section{Form FIN - 3: Cash Flow Capacity}

Specify proposed sources of financing, such as working capital, liquid assets, ${ }^{1}$ lines of credit, and other financial resources (other than any contractual advance payments) available to meet the cash flow requirements indicated under Criterion 2.4.3 (Contract Type B) of Section 3 (Evaluation and Qualification Criteria).

\begin{tabular}{|l|l|l|}
\hline \multicolumn{2}{|c|}{ Financial Resources } \\
\hline No. & Source of financing & Amount (\$ equivalent) \\
\hline 1 & & \\
\hline 2 & & \\
\hline 3 & & \\
\hline & & \\
\hline
\end{tabular}

Note: This form shall be included only if Criterion 2.4.3 (Contract Type B) of Section 3 (Evaluation and Qualification Criteria) is applicable.

Liquid assets mean cash and cash equivalents, short-term financial instruments, short-term available-for-sale-securities, marketable securities, trade receivables, short-term financing receivables, and other assets that can be converted into cash within 1 year. 


\section{Section 5: Eligible Countries}

This section contains the list of eligible countries. Please choose one of the following cases and follow the instructions as appropriate.

\section{NOTES}

For Contracts to be financed by loans/grants from

1. OCR without cofinancing resources:

Unless a waiver of $A D B$ member procurement eligibility restrictions was approved by the ADB Board of Directors, please insert the most recent list of $A D B$ members obtainable from www.adb.org/about/members

EXCEPTION: If any other contract under the project is financed by cofinancing resources that are administered by ADB (other than those listed in paragraph 2 below), then please state "No nationality restrictions apply, other than any restrictions arising from ITB 4.8."

2. Regular loan from $O C R$ with cofinancing resources from any one of the following funds:
(i) Asian Clean Energy Fund,
(ii) Japan Fund for Poverty Reduction,
(iii) Investment Climate Facilitation Fund,
(iv) Japan Fund for the Joint Credit Mechanism, and
(v) e-Asia and Knowledge Partnership Fund,

Unless a waiver of $A D B$ member procurement eligibility restrictions was approved by the $A D B$ Board of Directors, please insert the most recent list of $A D B$ members obtainable from www.adb.org/about/members

3. Concessional loan from OCR with cofinancing resources from any one of the following funds:
(i) Asian Clean Energy Fund,
(ii) Japan Fund for Poverty Reduction,
(iii) Japan Fund for Public Policy Training,
(iv) Japan Fund for Information and Communication Technology,
(v) Investment Climate Facilitation Fund, and
(vi) e-Asia and Knowledge Partnership Fund,

Unless a waiver of $A D B$ member procurement eligibility restrictions was approved by the $A D B$ Board of Directors, please insert the most recent list of $A D B$ members obtainable from www.adb.org/about/members

4. Regular loan from $O C R$ with cofinancing resources other than those listed in paragraph 2 above:

Please state "No nationality restrictions apply, other than any restrictions arising from ITB 4.8."

5. Concessional loan from $O C R$ with cofinancing resources other than those listed in paragraph 3 above:

Please state "No nationality restrictions apply, other than any restrictions arising from ITB 4.8." 
6. ADF without cofinancing resources:

Unless a waiver of $A D B$ member procurement eligibility restrictions was approved by the ADB Board of Directors, please insert the most recent list of $A D B$ developed members that have contributed to ADF resources, and all $A D B$ developing member countries.

EXCEPTION: If any other contract under the project is financed by cofinancing resources that are administered by ADB (other than those listed in paragraph 7 below), then please state "No nationality restrictions apply, other than any restrictions arising from ITB 4.8."

7. ADF with cofinancing resources from any one of the following funds:

(i) Asian Clean Energy Fund,

(ii) Japan Fund for Poverty Reduction,

(iii) Japan Fund for Public Policy Training,

(iv) Japan Fund for Information and Communication Technology,

(v) Investment Climate Facilitation Fund, and

(vi) e-Asia and Knowledge Partnership Fund,

Unless a waiver of $A D B$ member procurement eligibility restrictions was approved by the ADB Board of Directors, please insert the most recent list of $A D B$ developed members that have contributed to $A D F$ resources, and all $A D B$ developing member countries.

8. ADF with cofinancing resources other than those listed in paragraph 7 above:

Please state "No nationality restrictions apply, other than any restrictions arising from ITB 4.8." 


\section{Section 6: Schedule of Supply}

The Schedule of Supply shall provide sufficient information to enable Bidders to efficiently and accurately prepare Bids that are realistic and competitive. The Schedule of Supply is a Contract document and, therefore, it is a part of the Contract. The Purchaser must prepare the Schedule of Supply and include it as a part of the Bidding Document.

The Schedule of Supply should be complete, precise, and clear. An incomplete, imprecise, or unclear Schedule of Supply may prompt Bidders to require clarifications from the Purchaser or to submit conditional bids or bids that may be based on different understandings of the Purchaser's requirements. Depending on the nature of the clarifications, the Purchaser may need to amend the Bidding Document and eventually to extend the bid submission deadline. Conditional bids would have to be rejected. Bids that are not comparable cannot be evaluated.

The Purchaser shall assign experienced staff to draft the Schedule of Supply in a manner permitting the widest possible competition, while at the same time clearly specifying the required standards of workmanship, the characteristics of materials and performance of the Goods, and the delivery and completion of the Goods and Related Services. Only by following this approach will the Purchaser ensure that the objectives of economy, efficiency, fairness, and transparency in procurement can be realized as envisaged under open competitive bidding procedures.

The Schedule of Supply consists of four parts:

1. List of Goods and Related Services

2. Delivery and Completion Schedule

3. Technical Specifications

4. Drawings

The following notes provide guidance on how to prepare each part. 


\section{List of Goods and Related Services}

The purpose of the List of Goods and Related Services (LGRS) is to briefly describe and specify the quantity of each of the Goods and Related Services that the Purchaser requires the Bidder to include in its Bid. As a part of the Schedule of Supply, the LGRS constitutes a Contract document and, therefore, it is a part of the Contract. The Purchaser must prepare the LGRS and include it as a part of the Schedule of Supply.

If the Goods and Related Services are grouped in lots, the Purchaser must state whether Bidders are permitted to submit Bids for individual lots or not. For example,

[Alternative 1. Insert: "The Goods and Related Services are grouped in lots. Bids on individual lots are not permitted. Only Bids for all of the lots will be accepted."]

[Alternative 2. Insert: "The Goods and Related Services are grouped in lots. Bidders shall have the option of submitting Bids for one, any combination, or all of the lots. Lots shall not be further subdivided for the purpose of bidding."]

Lot No.: [if applicable]

Lot Name: [if applicable]

\begin{tabular}{|c|c|c|c|c|}
\hline Item No. & $\begin{array}{c}\text { Name of Goods or } \\
\text { Related Services }\end{array}$ & Description & $\begin{array}{c}\text { Unit of } \\
\text { Measurement }\end{array}$ & Quantity \\
\hline & & & & \\
\hline & & & & \\
\hline
\end{tabular}

Lot No.: [if applicable]

Lot Name: [if applicable]

\begin{tabular}{|l|l|l|l|l|}
\hline Item No. & $\begin{array}{c}\text { Name of Goods or } \\
\text { Related Services }\end{array}$ & Description & $\begin{array}{c}\text { Unit of } \\
\text { Measurement }\end{array}$ & Quantity \\
\hline & & & & \\
\hline & & & & \\
\hline
\end{tabular}

Lot No.: [if applicable]

Lot Name: [if applicable]

\begin{tabular}{|c|c|c|c|c|}
\hline Item No. & $\begin{array}{c}\text { Name of Goods or } \\
\text { Related Services }\end{array}$ & Description & $\begin{array}{c}\text { Unit of } \\
\text { Measurement }\end{array}$ & Quantity \\
\hline & & & & \\
\hline & & & & \\
\hline
\end{tabular}




\section{Delivery and Completion Schedule}

The purpose of the Delivery and Completion Schedule (DCS) is to specify the delivery dates and places for each of the Goods and the delivery places and completion dates for each of the Related Services as listed in the LGRS. The DCS, as part of the Schedule of Supply, constitutes a Contract document and, therefore, it is a part of the Contract. The Purchaser must prepare the DCS and include it as a part of the Schedule of Supply.

In preparing the DCS, the Purchaser should take into account the following:

(a) The delivery and completion dates should be realistic. Unrealistically short delivery or completion expectations may result in restricted competition or may prompt complaints from prospective Bidders.

(b) The date or period for delivery should be carefully specified, taking into account that the delivery terms stipulated must be consistent with

- the Incoterms EXW, CIF, CIP, CPT, FOB, FCR, FCA where delivery of goods takes place when delivered to the custody of the first carrier, and not the place established as the "named place of destination," and

- the date specified in the Contract for the start of the Purchaser's obligations (i.e., Notification of Award, date of signing the Contract Agreement, opening or confirmation of the letter of credit).

To determine the realistic arrival dates of the goods at their final destinations, the Purchaser has to take into account the additional time that will be needed for international or national transit to the project site or to another common place of destination.

Delivery may be specified for a single shipment, or for several partial shipments, for a specific date, or a range of acceptable delivery periods.

For example, the following provision may be used:

The delivery period shall start as of: ...... [Insert: either "the date of the Notification of Award," or "the date of signing the Contract Agreement," or "the date of opening the letter of credit," or "the date of confirmation of the letter of credit"] .......

Delivery shall take place in compliance with the dates, duration, and locations indicated below:

\begin{tabular}{|c|c|c|c|c|}
\hline $\begin{array}{c}\text { Item } \\
\text { No. }\end{array}$ & $\begin{array}{c}\text { Description of Goods } \\
\text { or Related Services }\end{array}$ & Delivery Schedule & Location & $\begin{array}{c}\text { Required Arrival } \\
\text { Date of Goods or } \\
\text { Completion Date for } \\
\text { Related Services }\end{array}$ \\
\hline $\begin{array}{c}{[\text { insert }} \\
\text { no. of } \\
\text { item }]\end{array}$ & $\begin{array}{c}{[\text { insert name and brief description of }} \\
\text { the goods and the related services to } \\
\text { be provided }]\end{array}$ & $\begin{array}{c}\text { [insert date } \\
\text { (dd/mm/yy) before } \\
\text { which or duration } \\
\text { days/weeks/months }) \\
\text { during which delivery } \\
\text { must take place }]\end{array}$ & $\begin{array}{c}\text { [insert place of } \\
\text { destination for goods } \\
\text { or site where services } \\
\text { shall be performed] }\end{array}$ & $\begin{array}{c}\text { [insert envisaged arrival } \\
\text { date of goods at final } \\
\text { destination } \\
\text { or }\end{array}$ \\
$\begin{array}{c}\text { desired completion date for } \\
\text { related services] }\end{array}$ \\
\hline
\end{tabular}




\section{Technical Specifications}

The purpose of the Technical Specifications is to define the technical characteristics of the Goods and Related Services required by the Purchaser. The Technical Specifications, as a part of the Schedule of Supply, constitute a Contract document and are, therefore, a part of the Contract. The Purchaser must prepare the Technical Specifications and include them as a part of the Bidding Document, as applicable to each Contract.

In preparing the Technical Specifications, the Purchaser should take into account the following:

(a) Well-prepared Technical Specifications will facilitate the examination, evaluation, and comparison of the Bids by the Purchaser, as Technical Specifications constitute the benchmarks against which the Purchaser will verify the technical responsiveness of Bids and subsequently evaluate the Bids.

(b) The Technical Specifications should require that all goods and materials to be incorporated in the Goods be new, unused, and of the most recent or current models, and that they incorporate all recent improvements in design and materials, unless otherwise provided for in the Contract.

(c) The Technical Specifications should make use of best practices: samples of specifications from successful similar procurement in the same country or sector may provide a sound basis for drafting the Technical Specifications.

(d) Technical Specifications should be established bearing in mind the environmental impacts at all stages of a product's life cycle, from its source of origin through its transport, use, and disposal.

(e) ADB encourages the use of metric units.

(f) Standardizing Technical Specifications under General Technical Specifications may be advantageous, depending on the complexity of the Goods and the repetitiveness of the type of procurement. Technical Specifications must be broad enough to avoid restrictions on workmanship, materials, and equipment commonly involved in manufacturing similar kinds of goods, even if these may not necessarily apply to a particular procurement. Particular technical requirements for a particular procurement would be specified in each case through deletions or addenda to the General Technical Specifications.

(g) Recognized international standards should be specified as much as possible. When other particular standards or codes of practice are referred to in the Technical Specifications, whether from the Borrower's or from other eligible countries, they must be followed by a statement that other authoritative standards that ensure at least a substantially equal quality to the standards mentioned in the Technical Specifications, will also be acceptable.

(h) Reference to brand names and catalogue numbers should be avoided as far as possible; where unavoidable the words "or at least equivalent" shall always follow such references.

(i) Technical Specifications shall be fully descriptive of the requirements in respect of, but not limited to, the following:

- standards of materials and workmanship required for the production and manufacture of the Goods;

- detailed tests required (type and number);

- other additional work and/or Related Services required to achieve full delivery and completion;

- detailed activities to be performed by the Supplier, and participation of the Purchaser therein; and

- list of detailed functional guarantees covered by the Warranty, and details of the penalties to be applied in the event that such guarantees are not met. 
(j) The Technical Specifications shall specify all essential technical and performance characteristics and requirements, including guaranteed or acceptable maximum or minimum values, as appropriate. Whenever necessary, the Purchaser shall include an additional ad hoc bidding form (to be an Attachment to the Bid Submission Sheet), where the Bidder shall provide detailed information on such technical performance characteristics in respect to the corresponding acceptable or guaranteed values.

(k) When the Purchaser stipulates that the Bidder must provide in its Bid a partor all of the Technical Specifications, technical schedules, or other technical information, the Purchaser shall specify in detail the nature and extent of the required information and the manner in which it must be presented by the Bidder in its Bid.

\section{Drawings}

The purpose of drawings is to specify locations, dimensions, materials to be used, stages of manufacturing, and other characteristics of the Goods and Related Services. The Purchaser should prepare such drawings, as needed, and include them in the Bidding Document. Such drawings, as part of the Schedule of Supply, are Contract documents and, therefore, shall be part of the Contract. Similarly, the Purchaser may request the Supplier to provide drawings either with its Bid or for approval during Contract execution.

It is essential that the Purchaser prepares a List of Drawings showing all drawings it supplied and issued as part of the Bidding Document. 


\section{Section 7: General Conditions of Contract}

The General Conditions Contract (GCC) contain standard provisions that have been designed to remain unchanged and to be used without modifying their text. The GCC clearly identify the provisions that may normally need to be specified for a particular bidding process and require that such specification be introduced through the Special Conditions of Contract (SCC).

The GCC are a Contract document and, therefore, are a part of the Contract.

\section{Table of Clauses}

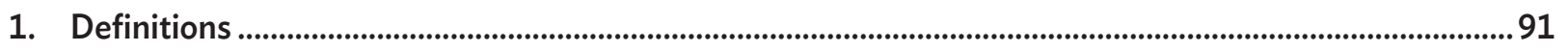

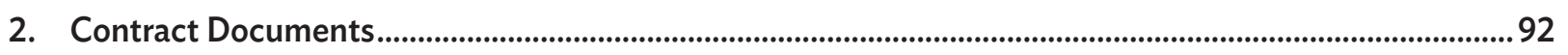

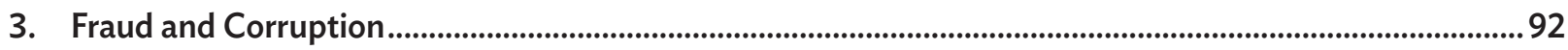

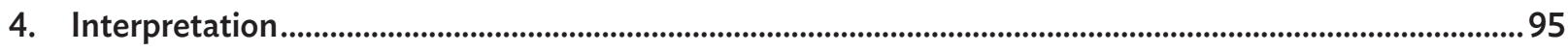

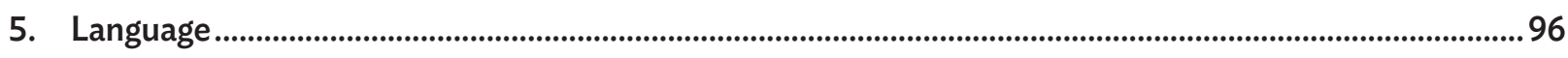

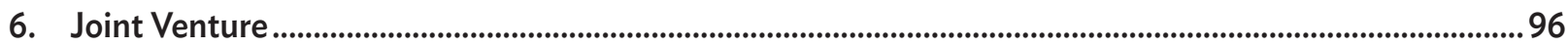

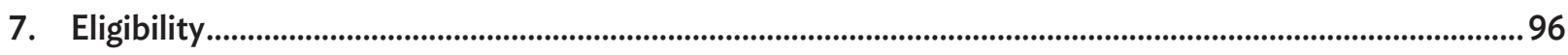

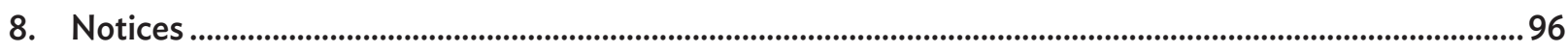

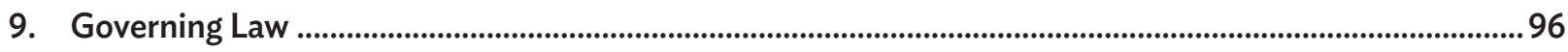

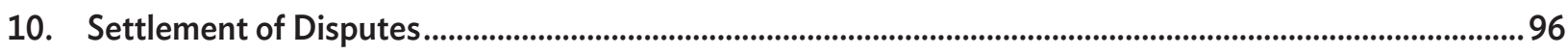

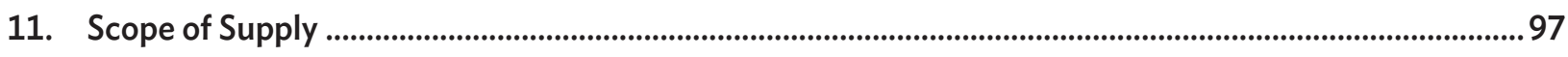

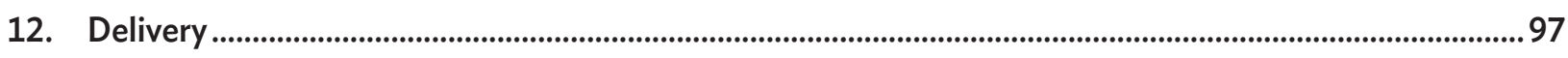

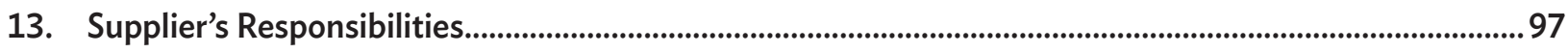

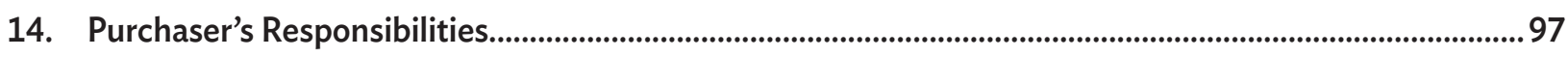

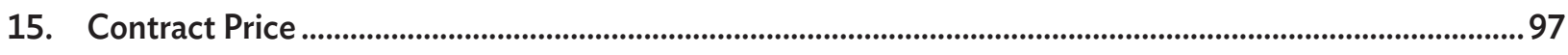

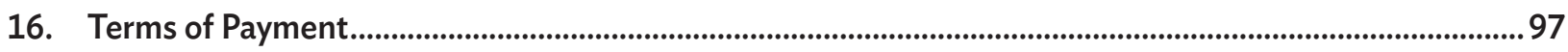

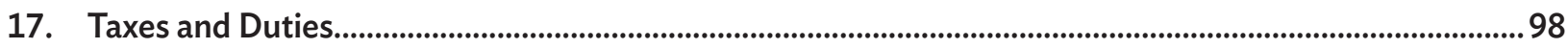

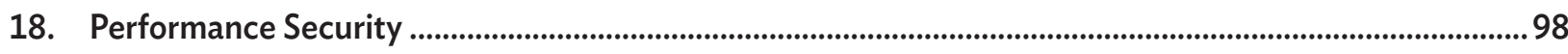




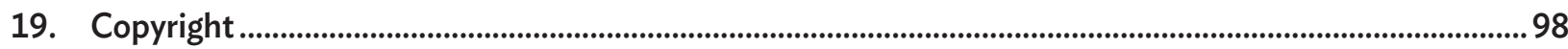

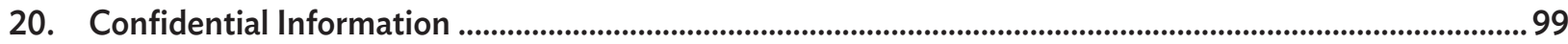

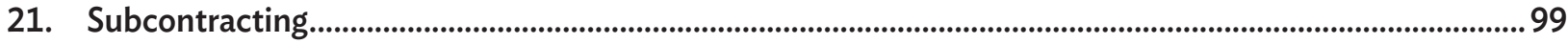

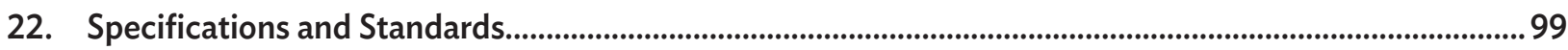

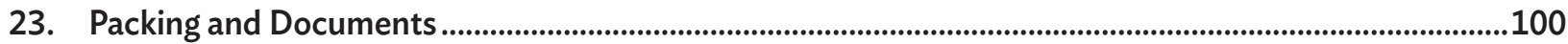

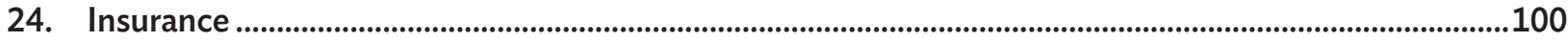

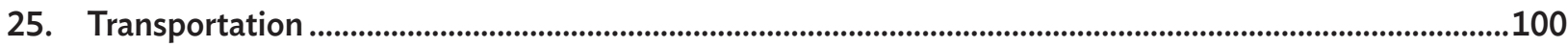

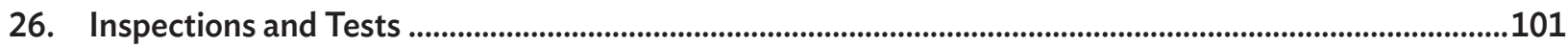

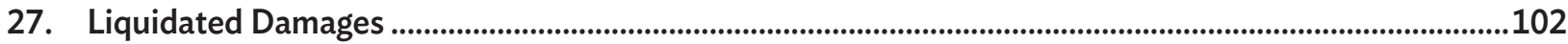

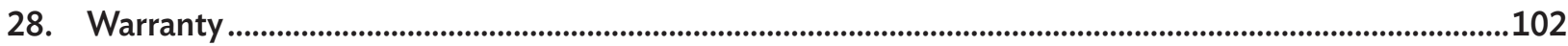

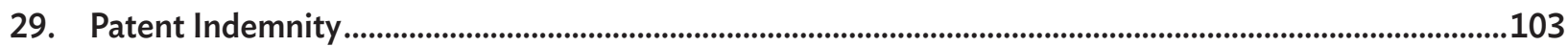

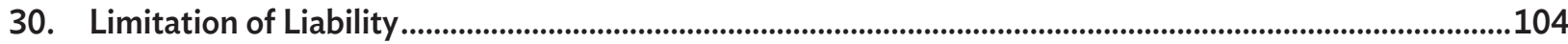

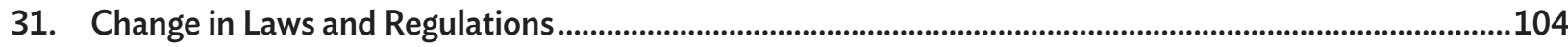

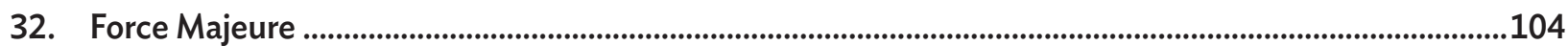

33. Change Orders and Contract Amendments...............................................................................................105

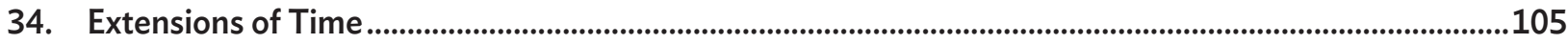

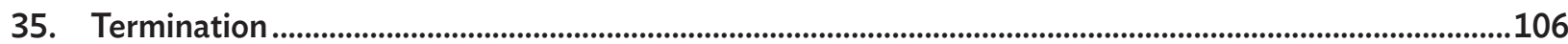

36. Assignment......................................................................................................................................................107

37. Respectful Work Environment ..........................................................................................................................107 
1. Definitions

1.1 The following words and expressions shall have the meanings hereby assigned to them:

(a) "Contract" means the Agreement entered into between the Purchaser and the Supplier, together with the Contract Documents referred to therein, including all attachments, appendixes, and all documents incorporated by reference therein.

(b) "Contract Documents" means the documents listed in the Agreement, including any amendments thereto.

(c) "Contract Price" means the price payable to the Supplier as specified in the Agreement, subject to such additions and adjustments thereto or deductions therefrom, as may be made pursuant to the Contract.

(d) "Day" means calendar day.

(e) "Delivery" means the transfer of the Goods from the Supplier to the Purchaser in accordance with the terms and conditions set forth in the Contract.

(f) "Completion" means the fulfillment of the Related Services by the Supplier in accordance with the terms and conditions set forth in the Contract.

(g) "Eligible Countries" means the countries and territories eligible as listed in Section 5.

(h) "GCC" means the General Conditions of Contract.

(i) "Goods" means all of the commodities, raw material, machinery and equipment, and/or other materials that the Supplier is required to supply to the Purchaser under the Contract.

(j) "Purchaser's Country" is the country specified in the Special Conditions of Contract (SCC).

(k) "Purchaser" means the entity purchasing the Goods and Related Services, as specified in the SCC.

(I) "Related Services" means the services incidental to the supply of the goods, such as insurance, installation, training and initial maintenance, and other similar obligations of the Supplier under the Contract.

(m) "SCC" means the Special Conditions of Contract.

(n) "Subcontractor" means any natural person, private or government entity, or a combination of the above, including its legal successors or permitted assigns, to whom any part of the Goods to be supplied or execution of any part of the Related Services is subcontracted by the Supplier.

(o) "Supplier" means the natural person, private or government entity, or a combination of the above, whose bid to perform the Contract has been accepted by the Purchaser and is named as such in the Agreement, and includes the legal successors or permitted assigns of the Supplier.

(p) "ADB" is the Asian Development Bank.

(q) "The Site," where applicable, means the place named in the SCC. 
2. Contract Documents

\section{Fraud and Corruption}

2.1 Subject to the order of precedence set forth in the Agreement, all documents forming the Contract (and all parts thereof) are intended to be correlative, complementary, and mutually explanatory.

3.1 If the Purchaser determines, based on reasonable evidence, that the Supplier has engaged in corrupt, fraudulent, collusive or coercive practices, or other integrity violations, including the failure to disclose any required information which constitutes a fraudulent practice, in competing for or in executing the Contract, then the Purchaser may, after giving 14 days' notice to the Supplier, terminate the Contract and expel him from the Site, and the provisions of Clause 35 shall apply as if such termination had been made under Sub-Clause 35.1 (a)(iii) [Termination].

3.2 ADB requires Borrowers (including beneficiaries of $A D B$-financed activity) and their personnel, as well as firms and individuals participating in an ADB-financed activity, including but not limited to, Bidders, Suppliers, and Contractors, agents, subcontractors, subconsultants, service providers, subsuppliers, manufacturers (including their respective officers, directors, employees and personnel) under ADB-financed contracts to observe the highest standard of ethics during the procurement and execution of such contracts in accordance with ADB's Anticorruption Policy (1998, as amended from time to time). In pursuance of this policy, ADB

(a) defines, for the purposes of this provision, the terms set forth below as follows:

(i) "corrupt practice" means the offering, giving, receiving, or soliciting, directly or indirectly, anything of value to influence improperly the actions of another party;

(ii) "fraudulent practice" means any act or omission, including a misrepresentation, that knowingly or recklessly misleads, or attempts to mislead, a party to obtain a financial or other benefit or to avoid an obligation;

(iii) "coercive practice" means impairing or harming, or threatening to impair or harm, directly or indirectly, any party or the property of the party to influence improperly the actions of a party;

(iv) "collusive practice" means an arrangement between two or more parties designed to achieve an improper purpose, including influencing improperly the actions of another party;

(v) "abuse" means theft, waste, or improper use of assets related to ADB-related activity, either committed intentionally or through reckless disregard;

(vi) "conflict of interest" means any situation in which a party has interests that could improperly influence that party's performance of official duties or responsibilities, contractual obligations, or compliance with applicable laws and regulations; 
(vii) Integrity Principles and Guidelines (2015, as amended from time to time), which violates ADB's Anticorruption Policy, including (i) to (vi) above and the following: obstructive practice, violations of ADB sanctions, retaliation against whistleblowers or witnesses, and other violations of ADB's Anticorruption Policy, including failure to adhere to the highest ethical standard.

(b) will reject a proposal for award if it determines that the Bidder recommended for award or any of its officers, directors, employees, personnel, subconsultants, subcontractors, service providers, suppliers or manufacturers has, directly or through an agent, engaged in corrupt, fraudulent, collusive, coercive, or obstructive practices or other integrity violations in competing for the Contract;

(c) will cancel the portion of the financing allocated to a contract if it determines at any time that representatives of the Borrower or of a beneficiary of ADB-financing engaged in corrupt, fraudulent, collusive, coercive, or obstructive practices or other integrity violations during the procurement or the execution of that contract, without the Borrower having taken timely and appropriate action satisfactory to $A D B$ to remedy the situation, including by failing to inform $A D B$ in a timely manner at the time they knew of the integrity violations;

(d) will impose remedial actions on a firm or an individual, at any time, in accordance with ADB's Anticorruption Policy and Integrity Principles and Guidelines, including declaring ineligible, either indefinitely or for a stated period of time, to participate ${ }^{1}$ in $A D B$-financed, -administered, or -supported activities or to benefit from an ADB-financed,-administered, or-supported contract, financially or otherwise, if it at any time determines that the firm or individual has, directly or through an agent, engaged in corrupt, fraudulent, collusive, coercive, or obstructive practices or other integrity violations; and

(e) will have the right to require that a provision be included in bidding documents and in contracts financed, administered, or supported by $A D B$, requiring Bidders, suppliers and contractors, consultants, manufacturers, service providers and other third parties engaged or involved in ADB-related activities, and their respective officers, directors, employees and personnel, to permit ADB or its representative to inspect the site and their assets, accounts and records and other documents relating to the bid submission and contract performance and to have them audited by auditors appointed by ADB.

Whether as a Contractor, Subcontractor, Consultant, Manufacturer or Supplier, or Service Provider; or in any other capacity (different names are used depending on the particular Bidding Document). 
3.3 All Bidders, consultants, contractors, suppliers, manufacturers, service providers, and other third parties engaged or involved in ADB-related activities and their respective officers, directors, employees and personnel, are obliged to cooperate fully in any investigation when requested by $A D B$ to do so. As determined on a case by case basis by ADB, such cooperation includes, but is not limited to, the following:

(a) being available to be interviewed and replying fully and truthfully to all questions asked;

(b) providing $\mathrm{ADB}$ with any items requested that are within the party's control including, but not limited to, documents and other physical objects;

(c) upon written request by $A D B$, authorizing other related entities to release directly to $A D B$ such information that is specifically and materially related, directly or indirectly, to the said entities or issues which are the subject of the investigation;

(d) cooperating with all reasonable requests to search or physically inspect their person and/or work areas, including files, electronic databases, and personal property used on ADB activities, or that utilizes ADB's Information and Communication Technology (ICT) resources or systems (including mobile phones, personal electronic devices, and electronic storage devices such as external disk drives);

(e) cooperating in any testing requested by ADB, including but not limited to, fingerprint identification, handwriting analysis, and physical examination and analysis; and

(f) preserving and protecting confidentiality of all information discussed with, and as required by, $\mathrm{ADB}$.

3.4 All Bidders, consultants, contractors and suppliers shall require their officers, directors, employees, personnel, agents to ensure that, in its contracts with its subconsultants, Subcontractors and other third parties engaged or involved in ADB-related activities, such sub-consultants, Subcontractors and other third parties similarly are obliged to cooperate fully in any investigation when requested by $\mathrm{ADB}$ to do so.

3.5 The Supplier shall permit ADB or its representative to inspect the Supplier's site, assets, accounts and records and other documents relating to the bid submission and contract performance of the Supplier and to have them audited by auditors appointed by $A D B$, if so required by $A D B$.

3.6 The Supplier undertakes that no fees, gratuities, rebates, gifts, commissions or other payments, other than those shown in the bid, have been given or received in connection with the procurement process or in the contract execution. ${ }^{2}$

2 The undertaking also applies during the period of performance of the contract. 
4. Interpretation
4.1 If the context so requires it, singular means plural and vice versa.

4.2 Incoterms

(a) The meaning of any trade term and the rights and obligations of parties thereunder shall be as prescribed by Incoterms.

(b) EXW, CIF, CIP, and other similar terms, shall be governed by the rules prescribed in the current edition of Incoterms, published by the International Chamber of Commerce at the date of the Invitation for Bids or as specified in the SCC.

\subsection{Entire Agreement}

The Contract constitutes the entire agreement between the Purchaser and the Supplier and supersedes all communications, negotiations, and agreements (whether written or oral) of parties with respect thereto made prior to the date of Contract.

\subsection{Amendment}

No amendment or other variation of the Contract shall be valid unless it is in writing, is dated, expressly refers to the Contract, and is signed by a duly authorized representative of each party thereto.

\subsection{Nonwaiver}

(a) Subject to GCC Subclause 4.5(b) below, no relaxation, forbearance, delay, or indulgence by either party in enforcing any of the terms and conditions of the Contract or the granting of time by either party to the other shall prejudice, affect, or restrict the rights of that party under the Contract, neither shall any waiver by either party of any breach of Contract operate as waiver of any subsequent or continuing breach of Contract.

(b) Any waiver of a party's rights, powers, or remedies under the Contract must be in writing, dated, and signed by an authorized representative of the party granting such waiver, and must specify the right and the extent to which it is being waived.

\subsection{Severability}

If any provision or condition of the Contract is prohibited or rendered invalid or unenforceable, such prohibition, invalidity, or unenforceability shall not affect the validity or enforceability of any other provisions and conditions of the Contract. 
5. Language

6. Joint Venture

7. Eligibility

8. Notices

9. Governing Law

10. Settlement of Disputes
5.1 The Contract as well as all correspondence and documents relating to the Contract exchanged by the Supplier and the Purchaser, shall be written in the language specified in the SCC. Supporting documents and printed literature that are part of the Contract may be in another language provided they are accompanied by an accurate translation of the relevant passages in the language specified in the SCC, in which case, for purposes of interpretation of the Contract, this translation shall govern.

5.2 The Supplier shall bear all costs of translation to the governing language and all risks of the accuracy of such translation.

6.1 If the Supplier is a Joint Venture, all of the parties shall be jointly and severally liable to the Purchaser for the fulfillment of the provisions of the Contract and shall designate one party to act as a leader with authority to bind the Joint Venture. The composition or the constitution of the Joint Venture shall not be altered without the prior consent of the Purchaser.

7.1 The Supplier and its Subcontractors shall have the nationality of an eligible country. A Supplier or Subcontractor shall be deemed to have the nationality of a country if it is a citizen or constituted, incorporated, or registered, and operates in conformity with the provisions of the laws of that country.

7.2 All Goods and Related Services to be supplied under the Contract and financed by $A D B$ shall have their origin in Eligible Countries. For the purpose of this clause, "country of origin" means the country where the goods have been grown, mined, cultivated, produced, manufactured, or processed; or through manufacture, processing, or assembly, another commercially recognized article results that differs substantially in its basic characteristics from its imported components.

8.1 Any Notice given by one party to the other pursuant to the Contract shall be in writing to the address specified in the SCC. The term "in writing" means communicated in written form with proof of receipt.

8.2 A Notice shall be effective when delivered or on the Notice's effective date, whichever is later.

9.1 The Contract shall be governed by and interpreted in accordance with the laws of the Purchaser's country, unless otherwise specified in the SCC.

10.1 The Purchaser and the Supplier shall make every effort to resolve amicably by direct informal negotiation any disagreement or dispute arising between them under or in connection with the Contract.

10.2 If the parties fail to resolve such a dispute or difference by mutual consultation within 28 days from the commencement of such consultation, either party may require that the dispute be referred for resolution to the formal mechanisms specified in the SCC. 
11. Scope of Supply

\section{Delivery}

\section{Supplier's Responsibilities}

\section{Purchaser's Responsibilities}

\section{Contract Price}

\section{Terms of Payment}

11.1 Subject to the SCC, the Goods and Related Services to be supplied shall be as specified in Section 6 (Schedule of Supply).

11.2 Unless otherwise stipulated in the Contract, the Scope of Supply shall include all such items not specifically mentioned in the Contract but that can be reasonably inferred from the Contract as being required for attaining Delivery and Completion of the Goods and Related Services as if such items were expressly mentioned in the Contract.

12.1 Subject to GCC Subclause 33.1, the Delivery of the Goods and Completion of the Related Services shall be in accordance with the Delivery and Completion Schedule specified in the Section 6 (Schedule of Supply). The details of shipping and other documents to be furnished by the Supplier are specified in the SCC.

13.1 The Supplier shall supply all the Goods and Related Services included in the Scope of Supply in accordance with GCC Clause 11, and the Delivery and Completion Schedule, as per GCC Clause 12.

14.1 Whenever the supply of Goods and Related Services requires that the Supplier obtain permits, approvals, and import and other licenses from local public authorities, the Purchaser shall, if so required by the Supplier, make its best effort to assist the Supplier in complying with such requirements in a timely and expeditious manner.

14.2 The Purchaser shall pay all costs involved in the performance of its responsibilities, in accordance with GCC Subclause 14.1.

15.1 The Contract Price shall be as specified in the Agreement subject to any additions and adjustments thereto, or deductions therefrom, as may be made pursuant to the Contract.

15.2 Prices charged by the Supplier for the Goods delivered and the Related Services performed under the Contract shall not vary from the prices quoted by the Supplier in its bid, with the exception of any price adjustments authorized in the SCC.

16.1 The Contract Price shall be paid as specified in the SCC.

16.2 The Supplier's request for payment shall be made to the Purchaser in writing, accompanied by invoices describing, as appropriate, the Goods delivered and Related Services performed, and by the documents submitted pursuant to GCC Clause 12 and upon fulfillment of all the obligations stipulated in the Contract.

16.3 Payments shall be made promptly by the Purchaser, no later than 60 days after submission of an invoice or request for payment by the Supplier, and the Purchaser has accepted it.

16.4 The currency or currencies in which payments shall be made to the Supplier under this Contract shall be specified in the SCC. 
17. Taxes and Duties

\section{Performance} Security

19. Copyright
17.1 For goods supplied from outside the Purchaser's country, the Supplier shall be entirely responsible for all taxes, stamp duties, license fees, and other such levies imposed outside the Purchaser's country.

17.2 For goods supplied from within the Purchaser's country, the Supplier shall be entirely responsible for all taxes, duties, license fees, etc., incurred until delivery of the contracted Goods to the Purchaser.

17.3 If any tax exemptions, reductions, allowances, or privileges may be available to the Supplier in the Purchaser's Country, the Purchaser shall use its best efforts to enable the Supplier to benefit from any such tax savings to the maximum allowable extent.

18.1 The Supplier shall, within 28 days of the notification of Contract award, provide a Performance Security for the due performance of the Contract in the amounts and currencies specified in the SCC.

18.2 The proceeds of the Performance Security shall be payable to the Purchaser as compensation for any loss resulting from the Supplier's failure to complete its obligations under the Contract.

18.3 The Performance Security shall be denominated in the currencies of the Contract, or in a freely convertible currency acceptable to the Purchaser, and shall be in one of the forms stipulated by the Purchaser in the SCC, or in another form acceptable to the Purchaser.

18.4 The Performance Security shall be discharged by the Purchaser and returned to the Supplier not later than 28 days following the date of completion of the Supplier's performance obligations under the Contract, including any warranty obligations, unless specified otherwise in the SCC.

19.1 The copyright in all drawings, documents, and other materials containing data and information furnished to the Purchaser by the Supplier herein shall remain vested in the Supplier, or, if they are furnished to the Purchaser directly or through the Supplier by any third party, including suppliers of materials, the copyright in such materials shall remain vested in such third party. 
20. Confidential Information

21. Subcontracting

22. Specifications and Standards
20.1 The Purchaser and the Supplier shall keep confidential and shall not, without the written consent of the other party hereto, divulge to any third party any documents, data, or other information furnished directly or indirectly by the other party hereto in connection with the Contract, whether such information has been furnished prior to, during, or following completion or termination of the Contract. Notwithstanding the above, the Supplier may furnish to its Subcontractor such documents, data, and other information it receives from the Purchaser to the extent required for the Subcontractor to perform its work under the Contract, in which event the Supplier shall obtain from such Subcontractor an undertaking of confidentiality similar to that imposed on the Supplier under GCC Clause 20.

20.2 The Purchaser shall not use such documents, data, and other information received from the Supplier for any purposes unrelated to the Contract. Similarly, the Supplier shall not use such documents, data, and other information received from the Purchaser for any purpose other than the design, procurement, or other work and services required for the performance of the Contract.

20.3 The obligation of a party under GCC Subclauses 20.1 and 20.2 above, however, shall not apply to information that

(a) the Purchaser or Supplier needs to share with ADB or other institutions participating in the financing of the Contract;

(b) now or hereafter enters the public domain through no fault of that party;

(c) can be proven to have been possessed by that party at the time of disclosure and which was not previously obtained, directly or indirectly, from the other party; or

(d) otherwise lawfully becomes available to that party from a third party that has no obligation of confidentiality.

20.4 The above provisions of GCC Clause 20 shall not in any way modify any undertaking of confidentiality given by either of the parties hereto prior to the date of the Contract in respect of the Supply or any part thereof.

20.5 The provisions of GCC Clause 20 shall survive completion or termination, for whatever reason, of the Contract.

21.1 The Supplier shall notify the Purchaser in writing of all subcontracts awarded under the Contract if not already specified in the Bid. Subcontracting shall in no event relieve the Supplier from any of its obligations, duties, responsibilities, or liability under the Contract.

21.2 Subcontracts shall comply with the provisions of GCC Clauses 3 and 7.

22.1 Technical Specifications and Drawings

(a) The Supplier shall ensure that the Goods and Related Services comply with the technical specifications and other provisions of the Contract.

(b) The Supplier shall be entitled to disclaim responsibility for any design, data, drawing, specification or other document, or any modification thereof provided or designed by or on behalf of the Purchaser, by giving a notice of such disclaimer to the Purchaser. 
(c) The Goods and Related Services supplied under this Contract shall conform to the standards mentioned in Section 6 (Schedule of Supply) and, when no applicable standard is mentioned, the standard shall be equivalent or superior to the official standards whose application is appropriate to the country of origin of the Goods.

22.2 Wherever references are made in the Contract to codes and standards in accordance with which it shall be executed, the edition or the revised version of such codes and standards shall be those specified in the Section 6 (Schedule of Supply). During Contract execution, any changes in any such codes and standards shall be applied only after approval by the Purchaser and shall be treated in accordance with GCC Clause 33.

\section{Packing and Documents}

24. Insurance

25. Transportation
23.1 The Supplier shall provide such packing of the Goods as is required to prevent their damage or deterioration during transit to their final destination, as indicated in the Contract. During transit, the packing shall be sufficient to withstand, without limitation, rough handling and exposure to extreme temperatures, salt and precipitation, and open storage. Packing case size and weights shall take into consideration, where appropriate, the remoteness of the final destination of the Goods and the absence of heavy handling facilities at all points in transit.

23.2 The packing, marking, and documentation within and outside the packages shall comply strictly with such special requirements as shall be expressly provided for in the Contract, including additional requirements, if any, specified in the SCC, and in any other instructions ordered by the Purchaser.

24.1 Unless otherwise specified in the SCC, the Goods supplied under the Contract shall be fully insured, in a freely convertible currency from an eligible country, against loss or damage incidental to manufacture or acquisition, transportation, storage, and delivery, in accordance with the applicable Incoterms or in the manner specified in the SCC.

25.1 Unless otherwise specified in the SCC, obligations for transportation of the Goods shall be in accordance with the Incoterms specified in Section 6 (Schedule of Supply). 


\section{Inspections and Tests}

26.1 The Supplier shall at its own expense and at no cost to the Purchaser carry out all such tests and/or inspections of the Goods and Related Services as are specified in Section 6 (Schedule of Supply).

26.2 The inspections and tests may be conducted on the premises of the Supplier or its Subcontractor, at point of delivery, and/or at the final destination of the Goods, or in another place in the Purchaser's country as specified in the SCC. Subject to GCC Subclause 26.3, if conducted on the premises of the Supplier or its Subcontractor, all reasonable facilities and assistance, including access to drawings and production data, shall be furnished to the inspectors at no charge to the Purchaser.

26.3 The Purchaser or its designated representative shall be entitled to attend the tests and/or inspections referred to in GCC Subclause 26.2, provided that the Purchaser bear all of its own costs and expenses incurred in connection with such attendance including, but not limited to, all traveling and board and lodging expenses.

26.4 Whenever the Supplier is ready to carry out any such test and inspection, it shall give a reasonable advance notice, including the place and time, to the Purchaser. The Supplier shall obtain from any relevant third party or manufacturer any necessary permission or consent to enable the Purchaser or its designated representative to attend the test and/or inspection.

26.5 The Purchaser may require the Supplier to carry out any test and/or inspection not required by the Contract but deemed necessary to verify that the characteristics and performance of the Goods comply with the technical specifications, codes, and standards under the Contract, provided that the Supplier's reasonable costs and expenses incurred in the carrying out of such test and/or inspection shall be added to the Contract Price. Further, if such test and/or inspection impedes the progress of manufacturing and/or the Supplier's performance of its other obligations under the Contract, due allowance will be made in respect of the Delivery Dates and Completion Dates and the other obligations so affected.

26.6 The Supplier shall provide the Purchaser with a report of the results of any such test and/or inspection.

26.7 The Purchaser may reject any Goods or any part thereof that fail to pass any test and/or inspection or do not conform to the specifications. The Supplier shall either rectify or replace such rejected Goods or parts thereof or make alterations necessary to meet the specifications at no cost to the Purchaser, and shall repeat the test and/or inspection, at no cost to the Purchaser, upon giving a notice pursuant to GCC Subclause 26.4.

26.8 The Supplier agrees that neither the execution of a test and/or inspection of the Goods or any part thereof, nor the attendance by the Purchaser or its representative, nor the issue of any report pursuant to GCC Subclause 26.6, shall release the Supplier from any warranties or other obligations under the Contract. 


\section{Liquidated Damages}

\section{Warranty}

27.1 Except as provided under GCC Clause 32, if the Supplier fails to deliver any or all of the Goods or perform the Related Services within the period specified in the Contract, the Purchaser may without prejudice to all its other remedies under the Contract, deduct from the Contract Price, as liquidated damages, a sum equivalent to the percentage specified in the SCC of the Contract Price for each week or part thereof of delay until actual delivery or performance, up to a maximum deduction of the percentage specified in the SCC. Once the maximum is reached, the Purchaser may terminate the Contract pursuant to GCC Clause 35.

28.1 The Supplier warrants that all the Goods are new, unused, and of the most recent or current models, and that they incorporate all recent improvements in design and materials, unless provided otherwise in the Contract.

28.2 Subject to GCC Subclause 22.1, the Supplier further warrants that the Goods shall be free from defects arising from any act or omission of the Supplier or arising from design, materials, and workmanship, under normal use in the conditions prevailing in the country of final destination.

28.3 Unless otherwise specified in the SCC, the warranty shall remain valid for 12 months after the Goods, or any portion thereof as the case may be, have been delivered to and accepted at the final destination indicated in the SCC, or for 18 months after the date of shipment or loading in the country of origin, whichever period concludes earlier.

28.4 The Purchaser shall give Notice to the Supplier, stating the nature of any such defects together with all available evidence thereof, promptly following the discovery thereof. The Purchaser shall afford all reasonable opportunity for the Supplier to inspect such defects.

28.5 Upon receipt of such Notice, the Supplier shall, within the period specified in the SCC, expeditiously repair or replace the defective Goods or parts thereof, at no cost to the Purchaser.

28.6 If having been notified, the Supplier fails to remedy the defect within the period specified in the SCC, the Purchaser may proceed to take within a reasonable period such remedial action as may be necessary, at the Supplier's risk and expense and without prejudice to any other rights which the Purchaser may have against the Supplier under the Contract. 
29. Patent Indemnity

29.1 The Supplier shall, subject to the Purchaser's compliance with GCC Subclause 29.2, indemnify and hold harmless the Purchaser and its employees and officers from and against any and all suits, actions or administrative proceedings, claims, demands, losses, damages, costs, and expenses of any nature, including attorney's fees and expenses, which the Purchaser may suffer as a result of any infringement or alleged infringement of any patent, utility model, registered design, trademark, copyright, or other intellectual property right registered or otherwise existing at the date of the Contract by reason of

(a) the installation of the Goods by the Supplier or the use of the Goods in the country where the Site is located; and

(b) the sale in any country of the products produced by the Goods.

Such indemnity shall not cover any use of the Goods or any part thereof other than for the purpose indicated by or to be reasonably inferred from the Contract, neither any infringement resulting from the use of the Goods or any part thereof, or any products produced thereby in association or combination with any other equipment, plant, or materials not supplied by the Supplier, pursuant to the Contract.

29.2 If any proceedings are brought or any claim is made against the Purchaser arising out of the matters referred to in GCC Subclause 29.1, the Purchaser shall promptly give the Supplier a notice thereof, and the Supplier may at its own expense and in the Purchaser's name conduct such proceedings or claim and any negotiations for the settlement of any such proceedings or claim.

29.3 If the Supplier fails to notify the Purchaser within 28 days after receipt of such notice that it intends to conduct any such proceedings or claim, then the Purchaser shall be free to conduct the same on its own behalf.

29.4 The Purchaser shall, at the Supplier's request, afford all available assistance to the Supplier in conducting such proceedings or claim, and shall be reimbursed by the Supplier for all reasonable expenses incurred in so doing.

29.5 The Purchaser shall indemnify and hold harmless the Supplier and its employees, officers, and Subcontractors from and against any and all suits, actions or administrative proceedings, claims, demands, losses, damages, costs, and expenses of any nature, including attorney's fees and expenses, which the Supplier may suffer as a result of any infringement or alleged infringement of any patent, utility model, registered design, trademark, copyright, or other intellectual property right registered or otherwise existing at the date of the Contract arising out of or in connection with any design, data, drawing, specification, or other documents or materials provided or designed by or on behalf of the Purchaser. 
30. Limitation of Liability

\section{Change in Laws and Regulations}

\section{Force Majeure}

30.1 Except in cases of gross negligence or willful misconduct,

(a) neither party shall be liable to the other party for any indirect or consequential loss or damage, loss of use, loss of production, or loss of profits or interest costs, provided that this exclusion shall not apply to any obligation of the Supplier to pay liquidated damages to the Purchaser; and

(b) the aggregate liability of the Supplier to the Purchaser, whether under the Contract, in tort, or otherwise, shall not exceed the amount specified in the SCC, provided that this limitation shall not apply to the cost of repairing or replacing defective equipment, or to any obligation of the Supplier to indemnify the Purchaser with respect to patent infringement.

31.1 Unless otherwise specified in the Contract, if after the date of the Invitation for Bids, any law, regulation, ordinance, order or bylaw having the force of law is enacted, promulgated, abrogated, or changed in the place of the Purchaser's country where the Site is located (which shall be deemed to include any change in interpretation or application by the competent authorities) that subsequently affects the Delivery Date and/or the Contract Price, then such Delivery Date and/or Contract Price shall be correspondingly increased or decreased, to the extent that the Supplier has thereby been affected in the performance of any of its obligations under the Contract. Notwithstanding the foregoing, such additional or reduced cost shall not be separately paid or credited if the same has already been accounted for in the price adjustment provisions where applicable, in accordance with GCC Clause 15.

32.1 The Supplier shall not be liable for forfeiture of its Performance Security, liquidated damages, or termination for default if and to the extent that its delay in performance or other failure to perform its obligations under the Contract is the result of an event of Force Majeure.

32.2 For purposes of this clause, "Force Majeure" means an event or situation beyond the control of the Supplier that is not foreseeable, is unavoidable, and its origin is not due to negligence or lack of care on the part of the Supplier. Such events may include, but not be limited to, acts of the Purchaser in its sovereign capacity, wars or revolutions, fires, floods, epidemics, quarantine restrictions, and freight embargoes.

32.3 If a Force Majeure situation arises, the Supplier shall promptly notify the Purchaser in writing of such condition and the cause thereof. Unless otherwise directed by the Purchaser in writing, the Supplier shall continue to perform its obligations under the Contract as far as is reasonably practical, and shall seek all reasonable alternative means for performance not prevented by the Force Majeure event. 
33. Change Orders and Contract Amendments

\section{Extensions} of Time
33.1 The Purchaser may at any time order the Supplier through Notice in accordance with GCC Clause 8, to make changes within the general scope of the Contract in any one or more of the following:

(a) drawings, designs, or specifications, where Goods to be furnished under the Contract are to be specifically manufactured for the Purchaser;

(b) the method of shipment or packing;

(c) the place of delivery; and

(d) the Related Services to be provided by the Supplier.

33.2 If any such change causes an increase or decrease in the cost of, or the time required for, the Supplier's performance of any provisions under the Contract, an equitable adjustment shall be made in the Contract Price or in the Delivery and Completion Schedule, or both, and the Contract shall accordingly be amended. Any claims by the Supplier for adjustment under this Clause must be asserted within 28 days from the date of the Supplier's receipt of the Purchaser's change order.

33.3 Prices to be charged by the Supplier for any Related Services that might be needed but which were not included in the Contract shall be agreed upon in advance by the parties and shall not exceed the prevailing rates charged to other parties by the Supplier for similar services.

34.1 If at any time during performance of the Contract, the Supplier or its Subcontractors should encounter conditions impeding timely delivery of the Goods or completion of Related Services pursuant to GCC Clause 12, the Supplier shall promptly notify the Purchaser in writing of the delay, its likely duration, and its cause. As soon as practicable after receipt of the Supplier's notice, the Purchaser shall evaluate the situation and may at its discretion extend the Supplier's time for performance, in which case the extension shall be ratified by the parties by amendment of the Contract.

34.2 Except in case of Force Majeure, as provided under GCC Clause 32, a delay by the Supplier in the performance of its Delivery and Completion obligations shall render the Supplier liable to the imposition of liquidated damages pursuant to GCC Clause 27, unless an extension of time is agreed upon, pursuant to GCC Subclause 34.1. 
35. Termination
35.1 Termination for Default

(a) The Purchaser, without prejudice to any other remedy for breach of Contract, by Notice of default sent to the Supplier, may terminate the Contract in whole or in part,

(i) if the Supplier fails to deliver any or all of the Goods within the period specified in the Contract, or within any extension thereof granted by the Purchaser pursuant to GCC Clause 34; or

(ii) if the Supplier fails to perform any other obligation under the Contract.

(iii) if the Supplier, in the judgment of the Purchaser has engaged in integrity violations, as defined in GCC Clause 3, in competing for or in executing the Contract.

(b) In the event the Purchaser terminates the Contract in whole or in part, pursuant to GCC Clause 35.1(a), the Purchaser may procure, upon such terms and in such manner as it deems appropriate, Goods or Related Services similar to those undelivered or not performed, and the Supplier shall be liable to the Purchaser for any additional costs for such similar Goods or Related Services. However, the Supplier shall continue performance of the Contract to the extent not terminated.

\subsection{Termination for Insolvency}

The Purchaser may at any time terminate the Contract by giving Notice to the Supplier if the Supplier becomes bankrupt or otherwise insolvent. In such event, termination will be without compensation to the Supplier, provided that such termination will not prejudice or affect any right of action or remedy that has accrued or will accrue thereafter to the Purchaser.

\subsection{Termination for Convenience}

(a) The Purchaser, by Notice sent to the Supplier, may terminate the Contract, in whole or in part, at any time for its convenience. The Notice of termination shall specify that termination is for the Purchaser's convenience, the extent to which performance of the Supplier under the Contract is terminated, and the date upon which such termination becomes effective.

(b) The Goods that are complete and ready for shipment within 28 days after the Supplier's receipt of the Notice of termination shall be accepted by the Purchaser at the Contract terms and prices. For the remaining Goods, the Purchaser may elect

(i) to have any portion completed and delivered at the Contract terms and prices; and/or

(ii) to cancel the remainder and pay to the Supplier an agreed amount for partially completed Goods and Related Services and for materials and parts previously procured by the Supplier. 
36. Assignment

37. Respectful Work Environment
36.1 Neither the Purchaser nor the Supplier shall assign, in whole or in part, their obligations under this Contract, except with prior written consent of the other party.

37.1 The Contractor shall ensure that its employees and Subcontractors observe the highest ethical standards and refrain from any form of bullying, discrimination, misconduct and harassment, including sexual harassment and shall, at all times, behave in a manner that creates an environment free of unethical behavior, bullying, misconduct and harassment, including sexual harassment. The Contractor shall take appropriate action against any employees or Subcontractors, including suspension or termination of employment or subcontract, if any form of unethical or inappropriate behavior is identified.

37.2 The Contractor shall conduct training programs for its employees and Subcontractors to raise awareness on and prevent any form of bullying, discrimination, misconduct, and harassment including sexual harassment, and to promote a respectful work environment. The Contractor shall keep an up to date record of its employees and subcontractors who have attended and completed such training programs and provide such records to the Purchaser at their first written request. 


\section{Section 8: Special Conditions of Contract}

The Special Conditions of Contract (SCC) contain provisions that the GCC requirements be specified for a particular bidding process. The Purchaser should include at the time of issuing the Bidding Document, all information or specifications that the GCC indicate shall be provided in the SCC. No SCC Clause should be left blank.

To facilitate the preparation of the SCC, its clauses are numbered with same numbers as the corresponding GCC clauses. This Guide helps the Purchaser to input all information required. It includes an SCC format that summarizes all information to be provided.

The SCC is a Contract document and, therefore, is a part of the Contract. 


\section{Special Conditions of Contract}

The following Special Conditions of Contract $(\mathrm{SCC})^{1}$ shall supplement the General Conditions of Contract (GCC). Whenever there is a conflict, the provisions herein shall prevail over those in the GCC.

\begin{tabular}{|c|c|}
\hline GCC 1.1(j) & The Purchaser's country is: [insert name of country] \\
\hline GCC 1.1(k) & $\begin{array}{l}\text { The Purchaser is: [insert complete name] } \\
\text { [ThePurchaser should be the Executing Agency/Implementing Agency named in the Financing Agreement or } \\
\text { the entity authorized to carry out the procurement activities under the Project Administration Manual] }\end{array}$ \\
\hline GCC 1.1(q) & The Site is: [insert name and detailed information on the location of the site] \\
\hline GCC 4.2(b) & The version of Incoterms shall be: [indicate current edition of Incoterms] \\
\hline GCC 5.1 & $\begin{array}{l}\text { The language shall be: [insert "English"] } \\
\text { Language for translation of supporting documents and printed literature is: } \\
\text { [insert "English" for OCB]. }\end{array}$ \\
\hline GCC 8.1 & $\begin{array}{l}\text { For notices, the Purchaser's address is: } \\
\text { Attention: [insert full name of the person, if applicable] } \\
\text { Street address: [insert street address and number] } \\
\text { Floor/Room number: [insert floor and room number, if applicable] } \\
\text { City: [insert name of the city or town] } \\
\text { ZIP code: [insert postal (ZIP) code, if applicable] } \\
\text { Country: [insert name of country] } \\
\text { Telephone: [insert telephone number including country and city codes] } \\
\text { Fax: [insert fax number including country and city codes] } \\
\text { E-mail: [insert e-mail address, if applicable] }\end{array}$ \\
\hline GCC 9.1 & The governing law shall be: [insert name of state or country] \\
\hline GCC 10.2 & $\begin{array}{l}\text { The formal mechanism for the resolution of disputes shall be: [insert type and description] } \\
\text { For a contract with a Foreign Supplier: } \\
\text { Alternative 1: [insert: "In the case of a dispute between the Purchaser and the Supplier, } \\
\text { the dispute shall be settled by international arbitration conducted in accordance with } \\
\text { the Arbitration Rules of the Singapore International Arbitration Centre. The arbitration } \\
\text { procedure shall be administered by the Singapore International Arbitration Centre."] } \\
\text { Alternative 2: [insert: "In the case of a dispute between the Purchaser and the Supplier, the } \\
\text { dispute shall be settled by arbitration in accordance with the provisions of the United Nations } \\
\text { Commission on International Trade Law (UNCITRAL) Arbitration Rules."] } \\
\text { Alternative 3: [insert: "In the case of a dispute between the Purchaser and the Supplier, } \\
\text { the dispute shall be settled by arbitration under the Rules of Arbitration of the International } \\
\text { Chamber of Commerce by one or more arbitrators selected in accordance with said Rules."] } \\
\text { Place of arbitration: [should be a neutral venue (i.e., not in the Purchaser's country)] }\end{array}$ \\
\hline
\end{tabular}




\section{For a contract with a Local Supplier:}

"In the case of a dispute between the Purchaser and the Supplier, the dispute shall be settled by arbitration in accordance with the provisions of the local arbitration procedures in the Purchaser's country."

Place of arbitration: in the Purchaser's country.

GCC 11.1

The Scope of Supply shall be defined in: [insert "Section 6 (Schedule of Supply)" or indicate where the Scope of Supply shall be defined. At the time of awarding the contract, the Purchaser shall specify any change in the scope of supply with respect to Section 6 (Schedule of Supply) included in the Bidding Document. Such changes may be due, for instance, if the quantities of Goods and Related Services are increased or decreased at the time of award.]

GCC 12.1

Details of shipping and documents to be furnished by the Supplier shall be:

[For example insert:

"For Goods supplied from abroad as per Incoterms CIF or CIP:

Upon shipment, the Supplier shall notify the Purchaser and the Insurance Company by telex or fax the full details of the shipment, including Contract number, description of Goods, quantity, the vessel, the bill of lading number and date, port of loading, date of shipment, port of discharge, etc. The Supplier shall send the following documents to the Purchaser, with a copy to the Insurance Company:

(a) ...copies of the Supplier's invoice showing the description of the Goods, quantity, unit price, and total amount;

(b) original and...copies of the negotiable, clean, on-board bill of lading marked "freight prepaid" and ...copies of nonnegotiable bill of lading;

(c) ...copies of the packing list identifying contents of each package;

(d) insurance certificate;

(e) Manufacturer's or Supplier's warranty certificate;

(f) inspection certificate, issued by the nominated inspection agency, and the Supplier's factory inspection report; and

(g) certificate of origin.

The Purchaser shall receive the above documents at least 1 week before arrival of the Goods at the port or place of arrival and, if not received, the Supplier will be responsible for any consequent expenses.

For Goods from within the Purchaser's country as per Incoterm EXW:

Upon delivery of the Goods to the transporter, the Supplier shall notify the Purchaser and send the following documents to the Purchaser:

(a) copies of the Supplier's invoice showing the description of the Goods, quantity, unit price, and total amount;

(b) delivery note, railway receipt, or truck receipt;

(c) Manufacturer's or Supplier's warranty certificate;

(d) inspection certificate issued by the nominated inspection agency, and the Supplier's factory inspection report; and

(e) certificate of origin.

The Purchaser shall receive the above documents before the arrival of the Goods and, if not received, the Supplier will be responsible for any consequent expenses.] 
GCC 15.2

The price adjustments shall be: [indicate if prices under the contract shall be adjusted and, if so, insert the methodology for adjustment. Price adjustment is used where the contract period is of long duration (generally exceeds 18 months). It is normal procedure that prices payable to the contractor shall be subject to price adjustment during the performance of the Contract."]

[For example insert: "Pursuant to GCC Subclause 15.2, prices payable to the Supplier, as stated in the Contract, shall be subject to adjustment during performance of the Contract to reflect changes in the cost of labor and material components in accordance with the formula:

$$
P_{1}=P_{0 \times}\left(a+b \frac{L_{1}}{L_{0}}+c \frac{M_{1}}{M_{0}}\right)-P_{0}
$$

The terms in the formula have the following meanings:

$P_{1}=$ Price adjustment payable to the Supplier

$\mathrm{P}_{0}=$ Contract Price (base price)

$\mathrm{a}=$ fixed portion representing profit and overhead included in the Contract Price. (generally in the range of $5 \%-15 \%$ )

$b=$ estimated percentage of labor component in the Contract Price

$c=$ estimated percentage of material component in the Contract Price

Lo, L1 = labor indexes applicable to the appropriate industry in the country of origin of the Goods on the base date and on the date for adjustment, respectively

Mo, M1 = material indexes for the major raw material on the base date and on the date for adjustment, respectively, in the country of origin of the Goods

The coefficients $a, b$, and $c$ shall be specified by the Purchaser in the Bidding Document. The sum of the three coefficients should be one (1) in every application of the formula.

Base date $=28$ days prior to the deadline for submission of the Bids

Date of adjustment $=\ldots$. weeks prior to date of shipment (representing the mid-point of the period of manufacture)

The above price adjustment formula shall be invoked by either party subject to the following further conditions:

(a) Price adjustment will be applied only if the resulting increase or decrease is more than $\%$ of the Contract Price. (2\% would be an acceptable percentage.)

(b) No price adjustment shall be allowed beyond the original delivery dates unless specifically stated in the extension letter. As a rule, no price adjustment shall be allowed for periods of delay for which the Supplier is entirely responsible. The Purchaser will, however, be entitled to any decrease in the prices of the Goods and Related Services subject to adjustment.

(c) If the currency in which the Contract Price $\left(P_{0}\right)$ expressed is different from the currency of origin of the labor and material indexes, a correction factor will be applied to avoid incorrect adjustments of the Contract Price. The correction factor shall correspond to the ratio of exchange rates between the two currencies on the base date and the date for adjustment as defined above.

(d) No price adjustment shall be payable on the portion of the Contract Price paid to the Supplier as advance payment.] 


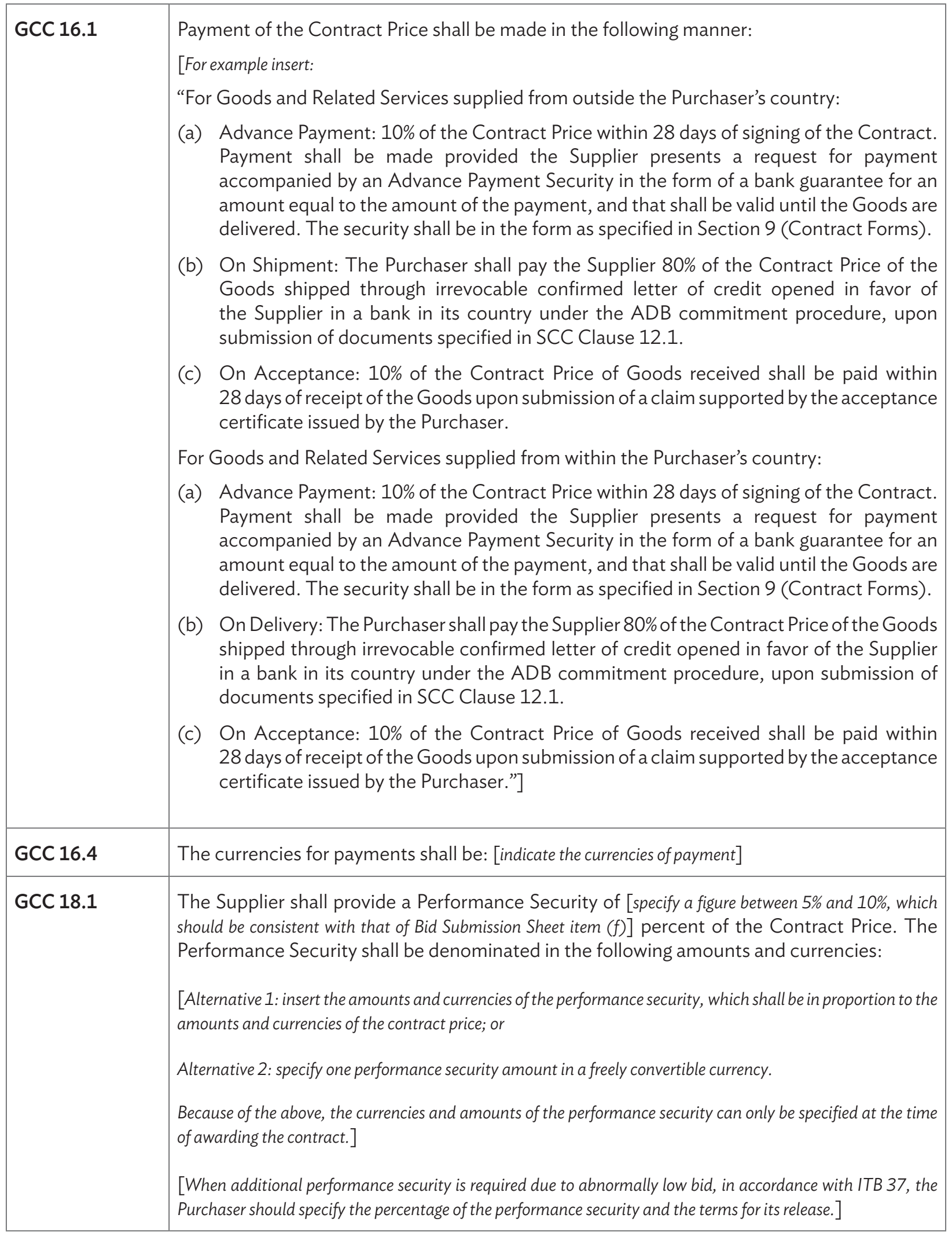




\begin{tabular}{|c|c|}
\hline GCC 18.3 & $\begin{array}{l}\text { The forms of acceptable Performance Securities are: [insert the name and description of performance } \\
\text { security acceptable to the purchaser and ADB.] } \\
\text { [For example insert: "A bank guarantee issued by a reputable bank located in the Purchaser's } \\
\text { country or abroad, acceptable to the Purchaser, in the format included in Section } 9 \text { (Contract } \\
\text { Forms), or a cashier's or certified check, or cash.] }\end{array}$ \\
\hline GCC 18.4 & $\begin{array}{l}\text { Discharge of the Performance Security shall take place: [insert (a) in accordance with GCC } \\
\text { Subclause 18.4; or (b) indicate how the performance security shall be discharged] } \\
\text { [For example insert: "Pursuant to GCC Subclause 18.4, after delivery and acceptance of the } \\
\text { Goods, the performance security shall be reduced to (specify percentage figure, i.e., 5\%) } \\
\text { percent of the Contract to cover the Supplier's warranty obligations in accordance with } \\
\text { GCC Clause } 28.3 . \text { "] }\end{array}$ \\
\hline GCC 23.2 & $\begin{array}{l}\text { The packing, marking, and documentation within and outside the packages shall be: [insert } \\
\text { in detail the type of packing, the markings, and all documentation required. Consideration should be given to } \\
\text { whether, during sea transport, the goods should be transported under deck. The provision must further expressly } \\
\text { provide details for markings and documentation to be required within and outside the packing cases.] }\end{array}$ \\
\hline GCC 24.1 & $\begin{array}{l}\text { The insurance coverage shall be in accordance with: [insert type of coverage, currency, and amount] } \\
\text { [For example insert: "Pursuant to GCC, Subclause } 24.1 \text {, the Supplier must insure the Goods in } \\
\text { an amount equal to } 110 \% \text { of the CIF, CIP or EXW price of the Goods from "Warehouse" to } \\
\text { "Warehouse" on "All Risks" basis, including War Risks and Strikes."] }\end{array}$ \\
\hline GCC 25.1 & $\begin{array}{l}\text { Obligations for transportation of the Goods shall be in accordance with: [indicate whether the } \\
\text { responsibility for transportation shall be in accordance with Incoterms or other trade terms.] }\end{array}$ \\
\hline GCC 26.2 & $\begin{array}{l}\text { Tests and Inspections specified in Section } 6 \text { (Schedule of Supply), shall be carried out at the } \\
\text { following times or milestones, and places: [Depending on the type of goods to be procured, there may be } \\
\text { a need to provide for special inspections and/or tests to be carried out. In particular, this will be the case when the } \\
\text { goods are designed specifically for the purpose of the project in question or where due to the nature of the goods, } \\
\text { there is a need to ensure compliance with certain technical specifications and requirements at an early stage. If } \\
\text { there is a need for such special inspections and/or tests, the SCC should mention specific testing methods and } \\
\text { the timing or milestones and places where the tests and/or inspections are to be carried out. For example, insert } \\
\text { for each test: } \\
\text { Goods: } \\
\text { Type of Test: } \\
\text { Time or Milestone: } \\
\text { Place: } \\
\text { Address: } \\
\text { Country: }\end{array}$ \\
\hline GCC 27.1 & $\begin{array}{l}\text { The applicable rate for liquidated damages for delay shall be: [insert rate, i.e., } 0.5 \% \text { of the contract } \\
\text { price per week or part thereof.] } \\
\text { The maximum amount of liquidated damages shall be [insert maximum amount for liquidated } \\
\text { damages, i.e., 10\% of the contract price] }\end{array}$ \\
\hline
\end{tabular}




\begin{tabular}{|l|l|}
\hline GCC 28.3 & $\begin{array}{l}\text { The period of validity of the Warranty shall be: [insert the period of validity of the warranty] } \\
\text { The place of final destination shall be: }\end{array}$ \\
\hline GCC 28.5 & $\begin{array}{l}\text { The Supplier shall correct any defects covered by the Warranty within [insert period, i.e., number } \\
\text { of days] of being notified by the Purchaser of the occurrence of such defects. }\end{array}$ \\
\hline GCC 30.1(b) & $\begin{array}{l}\text { The amount of aggregate liability shall be: [insert amount of aggregate liability i.e., 100\% of the } \\
\text { contract price] }\end{array}$ \\
\hline
\end{tabular}




\section{Section 9: Contract Forms}

Section 9 of the Bidding Document contains forms for the Notice of Intention for Award of Contract, Notification of Award, Contract Agreement, the Performance Security, and the Advance Payment Security. Bidders shall not submit these forms with their Bids. After notification of award, the Purchaser shall prepare the Contract Agreement using the Contract Agreement Form and send it to the successful Bidder. The successful Bidder shall sign the Contract Agreement and return it to the Purchaser together with the Performance Security and, if applicable, the Advance Payment Security, using the respective forms provided in Section 9. Bidders shall note that the Advance Payment Security is submitted only when the Contract specifies that there will be an advance payment.

\section{Table of Forms}

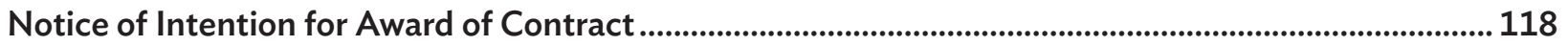

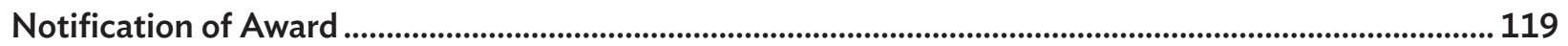

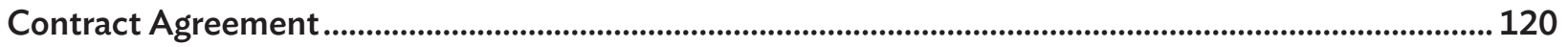

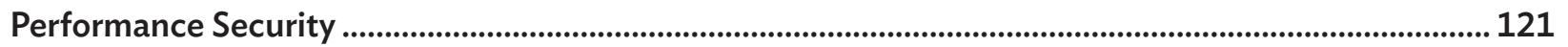

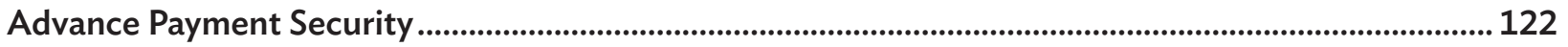




\section{Notice of Intention for Award of Contract}

[on letterhead paper of the Purchaser]

[date of notification]

To:

[name of the Bidder]

insert name of the Bidder's a

Address: [insert address of the Bidder's authorized representative]

Telephone/Fax numbers: [insert telephone/fax numbers of the Bidder's authorized representative]

E-mail Address: [insert e-mail address of the Bidder's authorized representative]

This is to notify you of our intention to award the contract [insert name of the contract and identification number, as given in the Bid Data Sheet]. You have [insert number of days as specified in ITB 40.1 of the BDS] days, from the date of this notification to (i) request for a debriefing in relation to the evaluation of your Bid, and/or (ii) submit a bidding-related complaint in relation to the intention for award of contract, in accordance with the procedures specified in ITB 46.1.

The summary of the evaluation are as follows:

1. List of Bidders [insert names of all bidders that submitted a bid together with the corresponding bid price at opening and evaluated bid price (if applicable)]

\begin{tabular}{|l|c|c|}
\hline Name of Bidder & $\begin{array}{c}\text { Bid Price as Read Out } \\
\text { at Opening }\end{array}$ & Evaluated Bid Price \\
\hline & & \\
\hline & & \\
\hline & & \\
\hline & & \\
\hline
\end{tabular}

\section{Reason/s Why Your Bid Was Unsuccessful}

[Provide reasons separately to each unsuccessful bidder why its bid was unsuccessful]

\section{The Successful Bidder}

\begin{tabular}{|l|l|}
\hline Name of Bidder: & \\
\hline Address: & \\
\hline Contract Price: & \\
\hline Duration of Contract: & \\
\hline Scope of the Contract Awarded: & \\
\hline Amount Performance Security Required: & \\
\hline
\end{tabular}

Authorized Signature:

Name and Title of Signatory:

Name of Agency:

\section{NOTE}

The Purchaser should send this notification simultaneously to each Bidder that submitted a bid. Notice of Intention for Award of Contract shall only be included if standstill provision is applicable in accordance with ITB 40.1. 


\section{Notification of Award}

[on letterhead of the Purchaser]

\section{Letter of Acceptance}

To: [name and address of the supplier]

Subject: Contract No. [please specify]

This is to notify you that your Bid dated [date] for execution of the [name of the contract and identification number, as given in the Bid Data Sheet] for the Accepted Contract Amount of the equivalent of [amount in words and figures and name of currency], as corrected and modified in accordance with the Instructions to Bidders is hereby accepted by our Agency.

You are requested to furnish the Performance Security within 28 days in accordance with the Conditions of Contract and any additional security required as a result of the evaluation of your bid, using for that purpose the Performance Security Form included in Section 9 (Contract Forms) of the Bidding Document.

Authorized Signature:

Name and Title of Signatory:

Name of Agency:

Attachment: Contract Agreement 


\section{Contract Agreement}

THIS AGREEMENT made on the [insert date] day of [insert month], [insert year], between [insert complete name of the Purchaser] of [insert complete address of the Purchaser] (hereinafter "the Purchaser"), of the one part, and [insert complete name of the supplier] of [insert complete address of the Supplier] (hereinafter "the Supplier"), of the other part:

WHEREAS the Purchaser invited Bids for certain Goods and Related Services, viz., [insert brief description of the goods and related services] and has accepted a Bid by the Supplier for the supply of those Goods and Related Services in the sum of [insert currency or currencies and amount of contract price in words and figures] (hereinafter "the Contract Price"),

NOW THIS AGREEMENT WITNESSETH AS FOLLOWS:

1. In this Agreement, words and expressions shall have the same meanings as are respectively assigned to them in the Conditions of Contract referred to.

2. The following documents shall be deemed to form and be read and construed as part of this Agreement, viz:

(a) Letter of Acceptance;

(b) Bid Submission Sheet and the Price Schedules submitted by the Supplier;

(c) Addenda Nos. [insert addenda numbers if any $]^{1}$

(d) Special Conditions of Contract;

(e) List of Eligible Countries that was specified in Section 5 of the Bidding Document;

(f) General Conditions of Contract;

(g) Schedule of Supply; and

(h) any other documents shall be added here.

This Contract shall prevail over all other Contract documents. In the event of any discrepancy or inconsistency within the Contract documents, then the documents shall prevail in the order listed above.

3. In consideration of the payments to be made by the Purchaser to the Supplier as indicated in this Agreement, the Supplier hereby covenants with the Purchaser to provide the Goods and Related Services and to remedy defects therein in conformity in all respects with the provisions of the Contract.

4. The Purchaser hereby covenants to pay the Supplier in consideration of the provision of the Goods and Related Services and the remedying of defects therein, the Contract Price or such other sum as may become payable under the provisions of the Contract at the times and in the manner prescribed by the Contract.

IN WITNESS whereof the parties hereto have caused this Agreement to be executed in accordance with the laws of [indicate name of country] on the day, month, and year indicated above.

Signed by [insert authorized signature for the Purchaser] (for the Purchaser)

Signed by [insert authorized signature for the supplier] (for the Supplier)

Information contained in the addenda and or addendum should preferably be included in the contract documents to avoid potential ambiguities during contract implementation. If however, unavoidable priority should be decided depending on the nature of information provided in the addenda/addendum. 


\section{Performance Security}

[Bank's name, and address of issuing branch or office $]^{1}$

Beneficiary:

[Name and address of the purchaser]

Date:

Performance Guarantee No.:

We have been informed that [name of the Supplier] (hereinafter called "the Supplier") has entered into Contract No. [reference number of the Contract] dated [date] with you, for the execution of [name of Contract and brief description of goods and related services] (hereinafter called "the Contract").

Furthermore, we understand that, according to the conditions of the Contract, a performance guarantee is required.

At the request of the Supplier, we [name of the bank] hereby irrevocably undertake to pay you any sum or sums not exceeding in total an amount of [name of the currency and amount in words] [ [amount in figures] such sum being payable in the types and proportions of currencies in which the Contract Price is payable, upon receipt by us of your first demand in writing accompanied by a written statement stating that the Supplier is in breach of its obligation(s) under the Contract, without your needing to prove or to show grounds for your demand or the sum specified therein.

This guarantee shall expire, no later than the [date]day of [month], [year], ${ }^{3}$ and any demand for payment under it must be received by us at this office on or before that date.

This guarantee is subject to the Uniform Rules for Demand Guarantees (URDG) 2010 Revisions, ICC Publication No. 758, except that the supporting statement under Article 15(a) is hereby excluded. ${ }^{4}$

.......................

[Signature(s) and seal of bank (where appropriate)]

\section{Note to Bidder}

If the bank issuing performance security is located outside the Purchaser's country, it shall be counter-guaranteed or encashable by a bank in the Purchaser's country.

All italicized text is for guidance on how to prepare this demand guarantee and shall be deleted from the final document. The guarantor shall insert an amount representing the percentage of the contract price specified in the contract and denominated either in the currency(ies) of the contract or in any freely convertible currency acceptable to the Purchaser. Insert the date 28 days after the expected completion date. The Purchaser should note that in the event of an extension of the time for completion of the contract, the Purchaser would need to request an extension of this guarantee from the guarantor. Such request must be in writing and must be made prior to the expiration date established in the guarantee. In preparing this guarantee, the Purchaser might consider adding the following text to the form, at the end of the penultimate paragraph: "The Guarantor agrees to a one-time extension of this guarantee for a period not to exceed [6 months] [1 year], in response to the Purchaser's written request for such extension, such request to be presented to the Guarantor before the expiry of the guarantee."

4 Or the purchaser may use " Uniform Rules for Demand Guarantees (URDG), ICC Publication No. 458, except that subparagraph (ii) of Sub-article 20(a) is hereby excluded" as appropriate. 


\section{Advance Payment Security}

[insert complete name and number of contract $]^{1}$

To: [insert complete name of the Purchaser]

In accordance with the payment provision included in the Contract, in relation to advance payments, [insert complete name of the Supplier] (hereinafter called "the Supplier") shall deposit with the Purchaser a security consisting of [indicate type of security], to guarantee its proper and faithful performance of the obligations imposed by said Clause of the Contract, in the amount of [insert currency and amount of guarantee in words and figures].

We, the undersigned [insert complete name of the guarantor], legally domiciled in [insert full address of the guarantor] (hereinafter "the Guarantor"), as instructed by the Supplier, agree unconditionally and irrevocably to guarantee as primary obligor and not as surety merely, the payment to the Purchaser on its first demand without whatsoever right of objection on our part and without its first claim to the Supplier, in the amount not exceeding [insert currency and amount of guarantee in words and figures].

This security shall remain valid and in full effect from the date of the advance payment being received by the Supplier under the Contract until [insert date (as day, month, year)].

This guarantee is subject to the Uniform Rules for Demand Guarantees (URDG) 2010 Revisions, ICC Publication No. 758, except that the supporting statement under Article 15(a) is hereby excluded. ${ }^{2}$

Name: [insert complete name of person signing the Security]

In the capacity of [insert legal capacity of person signing the Security]

Signed: [insert signature of person whose name and capacity are shown above]

Duly authorized to sign the security for and on behalf of [insert seal (where appropriate) and complete name of the guarantor] Date: [insert date of signing]

\section{Note to Bidder}

If the bank issuing advance payment security is located outside the Purchaser's country, it shall be counter-guaranteed or encashable by a bank in the Purchaser's country.

All italicized text is for guidance on how to prepare this demand guarantee and shall be deleted from the final document. Or the purchaser may use "Uniform Rules for Demand Guarantees (URDG), ICC Publication No. 458, except that subparagraph (ii) of Sub-article 20(a) is hereby excluded" as appropriate. 


\section{User Guide for Procurement of Goods Standard Bidding Document}

This User's Guide is intended to provide guidance to borrowers on how to prepare a bidding document for the procurement of goods and related services, and how to evaluate bids and award contracts, based on the Asian Development Bank's Standard Bidding Document for the Procurement of Goods, which is available for a single-stage bidding procedure. It is applicable to projects governed by the Procurement Regulations for ADB Borrowers: Goods, Works, Nonconsulting and Consulting Services (2017, as amended from time to time).

\section{About the Asian Development Bank}

ADB is committed to achieving a prosperous, inclusive, resilient, and sustainable Asia and the Pacific, while sustaining its efforts to eradicate extreme poverty. Established in 1966, it is owned by 68 members -49 from the region. Its main instruments for helping its developing member countries are policy dialogue, loans, equity investments, guarantees, grants, and technical assistance. 